\title{
STREAMFLOW GAIN-AND-LOSS \\ MEASUREMENTS AND WATER-QUALITY \\ DATA OF SALT CREEK AND ITS \\ TRIBUTARIES NEAR LINCOLN, \\ NEBRASKA, 1994-95
}

\section{U.S. GEOLOGICAL SURVEY}

Opper-File Repori 96-551

Prepared in cooperation with the

CITY OF LUNCOLN

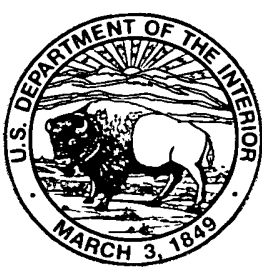




\section{STREAMFLOW GAIN-AND-LOSS}

MEASUREMENTS AND WATER-QUALITY

DATA OF SALT CREEK AND ITS

TRIBUTARIES NEAR LINCOLN,

NEBRASKA, 1994-95

By Ingrid M. Verstraeten

U.S. GEOLOGICAL SURVEY

Open-File Report 96-551

Prepared in cooperation with the CITY OF LINCOLN

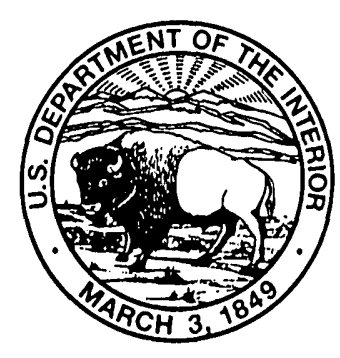




\section{U.S. DEPARTMENT OF THE INTERIOR \\ BRUCE BABBITT, Secretary}

U.S. GEOLOGICAL SURVEY

Gordon P. Eaton, Director

The use of firm, trade, and brand names in this report is for identification purposes only and does not constitute endorsement by the U.S. Geological Survey.

For additional information write to:

District Chief

U.S. Geological Survey

Water Resources Division

Room 406 Federal Building

100 Centennial Mall North

Lincoln, NE 68508
Copies of this report can be purchased from:

U.S. Geological Survey

Branch of Information Services

Box 25286

Denver, CO 80225-0286 


\section{CONTENTS}

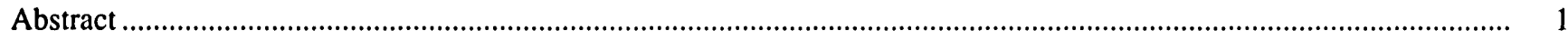

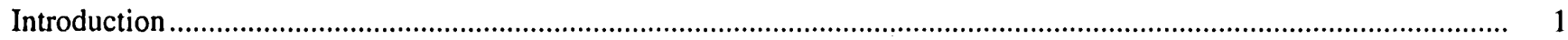

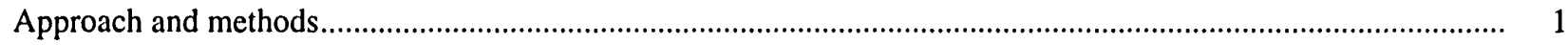

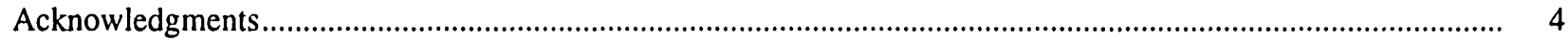

Gain-and-loss measurements of Salt Creek and its tributaries …............................................................................... 5

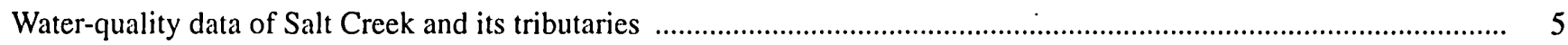

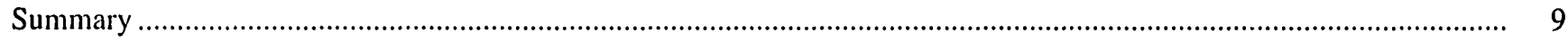

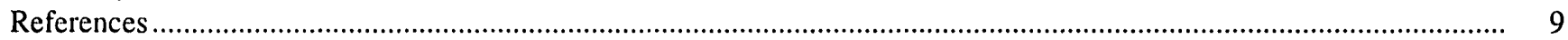

\section{ILLUSTRATIONS}

1. Map showing location of study area, sampling sites, gaging stations, and wastewater-treatment plants, Lincoln, Nebraska ...

2. Graphs showing discharge of the Theresa Street and Northeast Wastewater Treatment Plants of City of Lincoln, Nebraska, on (A) August 17, 1994, (B) September 29, 1994, and (C) August 30, $1995 .$.

3. Schematic diagram showing streamflow gain-and-loss measurements of Salt Creek and its tributaries from the Pioneers Boulevard gaging station to a site downstream from the mouth of Stevens Creek near Lincoln, Nebraska.

4-7. Hydrographs showing:

4. Flow of Salt Creek at Pioneers Boulevard (site 1), Haines Branch (site 15), Middle Creek (site 17), Salt Creek at 27th Street (site 6), Little Salt Creek (site 26), Salt Creek at 70th Street (site 9), and Stevens Creek (site 28) gaging stations and precipitation at the Lincoln Municipal Airport from June 1, 1994, through September 30, 1995, Lancaster County, Nebraska.

5. Flow at the gaging stations along Salt Creek at Pioneers Boulevard, 27th Street, and 70th Street and precipitation values for the Lincoln Municipal Airport precipitation station from June 1, 1994, through September 30, 1995, Lancaster County, Nebraska...

6. Flow at the Haines Branch (site 15), Middle Creek (site 17), Little Salt Creek (site 26), and Stevens Creek (site 28) gaging stations and precipitation at the Lincoln Municipal Airport from June 1, 1994, through September 30, 1995, Lancaster County, Nebraska.

7. Flow duration of Salt Creek at 27th Street gaging station 06803500 (site 6), 1949 through $1994 .$.

8. Graphs showing flow measurements of Salt Creek, its tributaries, and the Theresa Street and Northeast Wastewater Treatment Plants, Lincoln, Nebraska, June 20, 1994, August 16-17, 1994, September 28-29, 1994, and August 28-30, 1995

9-13. Maps showing:

9. Flow measurements at sampling sites on Salt Creek, its tributaries, and the Theresa Street and Northeast Wastewater Treatment Plants, Lincoln, Nebraska, June 20, 1994

10. Flow measurements at sampling sites on Salt Creek, its tributaries, and the Theresa Street and Northeast Wastewater Treatment Plants, Lincoln, Nebraska, August 16-17, 1994..

11. Flow measurements at sampling sites on Salt Creek, its tributaries, and the Theresa Street and Northeast Wastewater Treatment Plants, Lincoln, Nebraska, September 28-29, 1994.

12. Flow measurements at sampling sites on Salt Creek, its tributaries, and the Theresa Street and Northeast Wastewater Treatment Plants, Lincoln, Nebraska, August 28-30, 1995.

13. Mean flow measurements of Salt Creek, its tributaries, and the Theresa Street and Northeast Wastewater Treatment Plants, Lincoln, Nebraska, June 20, 1994, August 16-17, 1994', September 28-29, 1994, and August 28-30, 1995

14-15. Schematic diagrams showing:

14. Mean gain and loss per stream reach of Salt Creek from the Pioneers Boulevard gaging station to a site downstream from the mouth of Stevens Creek near Lincoln, Nebraska, June 20, 1994, August 16-17, 1994, September 28-29, 1994, and August 28-30, 1995.

15. Mean gain and loss per river mile of each stream reach of Salt Creek from the Pioneers Boulevard gaging station to a site downstream from the mouth of Stevens Creek near Lincoln, Nebraska, June 20, 1994, August 16-17, 1994, September 28-29, 1994, and August 28-30, 1995 
16-20. Maps showing:

16. Dissolved solids in surface-water samples from Salt Creek, its tributaries, and the Theresa Street and Northeast Wastewater Treatment Plants, Lincoln, Nebraska, August 28-30, 1995

17. Specific conductance in surface-water samples from Salt Creek, its tributaries, and the Theresa Street and Northeast Wastewater Treatment Plants, Lincoln, Nebraska, August 28-30, 1995

18. Total ammonia and organic nitrogen in surface-water samples from Salt Creek, its tributaries, and the Theresa Street and Northeast Wastewater Treatment Plants, Lincoln, Nebraska, August 28-30, 1995

19. Total phosphorus in surface-water samples from Salt Creek, its tributaries, and the Theresa Street and Northeast Wastewater Treatment Plants, Lincoln, Nebraska, August 28-30, 1995.

20. Dissolved chloride in surface-water samples from Salt Creek, its tributaries, and the Theresa Street and Northeast Wastewater Treatment Plants, Lincoln, Nebraska, August 28-30, 1995

\section{TABLES}

1. Listing of sampling sites on Salt Creek and tributaries near Lincoln, Nebraska, 1994-95

2. Flow measurements of Salt Creek, its tributaries, and the Theresa Street and Northeast Wastewater Treatment Plants, Lincoln, Nebraska, June 20, 1994, August 16-17, 1994, September 28-29, 1994, and August 28-30, 1995 .

3. Discharge gain-and-loss measurements along Salt Creek near Lincoln, Nebraska, June 20, 1994, August 16-17, 1994, September 28-29, 1994, and August 28-30, 1995.

4. Gains and losses per river mile along Salt Creek near Lincoln, Nebraska, June 20, 1994, August $16-17,1994$, September 28-29, 1994, and August 28-30, 1995

Field measurements and water-quality data from discharge at the Theresa Street and Northeast Wastewater Treatment Plants and from sites on Salt Creek and its tributaries, Lincoln, Nebraska, June 20, 1994, August 16-17, 1994, September 28-29, 1994, and August 28-30, 1995

6. Loads of selected constituents from discharge at the Theresa Street and Northeast Wastewater Treatment Plants and from sites on Salt Creek and its tributaries, Lincoln, Nebraska, June 20, 1994, August 16-17, 1994, September 28-29, 1994, and August 28-30, 1995

7. Mean field measurements and water-quality concentrations of selected constituents from discharge at the Theresa Street and Northeast Wastewater Treatment Plants and from sites on Salt Creek and its tributaries, Lincoln, Nebraska, 1994-95.

8. Percent contributions of flow and selected constituents detected in samples from the Theresa Street and Northeast Wastewater Treatment Plants, Salt Creek, and its tributaries, Lincoln, Nebraska, June 20, 1994, August 16-17, 1994, September 28-29, 1994, and August 28-30, 1995

9. Reductions or increases in concentrations or measurements of selected constituents from discharge at the Theresa Street and Northeast Wastewater Treatment Plants and from sites on Salt Creek and its tributaries, Lincoln, Nebraska, June 20, 1994, August 16-17, 1994, September 28-29, 1994, and August 28-30, 1995.

10. Gains and losses of selected loads from discharge at the Theresa Street and Northeast Wastewater Treatment Plants and from sites on Salt Creek and its tributaries, Lincoln, Nebraska, June 20, 1994, August 16-17, 1994, September 28-29, 1994, and August 28-30, 1995

CONVERSION FACTORS

\begin{tabular}{rll}
\hline Multiply & By & To obtain \\
\hline foot $(\mathrm{ft})$ & 0.3048 & meter \\
inch & 25.4 & millimeter \\
mile $(\mathrm{mi})$ & 1.609 & kilometer \\
square mile $\left(\mathrm{mi}^{2}\right)$ & 2.590 & square kilometer \\
cubic foot per second $\left(\mathrm{ft}^{3} / \mathrm{s}\right)$ & 0.02832 & cubic meter per second \\
pound per day $(\mathrm{lb} / \mathrm{d})$ & 0.4535 & kilogram per day \\
pound per day $(\mathrm{lb} / \mathrm{d})$ & $0.4535 \times 10^{-3}$ & ton per day \\
\hline
\end{tabular}




\title{
STREAMFLOW GAIN-AND-LOSS MEASUREMENTS AND WATER-QUALITY DATA OF SALT CREEK AND ITS TRIBUTARIES NEAR LINCOLN, NEBRASKA,
}

\section{4-95}

\author{
By Ingrid M. Verstraeten
}

\begin{abstract}
A 2-year study was completed to document streamflow gain and loss and to estimate loads of selected constituents in a reach of Salt Creek and its tributaries near Lincoln, Nebraska. Four gainand-loss investigations were conducted in 1994 and 1995 during low to moderate flow at 28 sites along a 13.78-mile reach of Salt Creek and along its tributaries. Water-quality samples were collected from 11 sites (4 sites in June 1994) along Salt Creek in 1994 and from 28 sites along Salt Creek and its tributaries, and the Theresa Street and Northeast Wastewater Treatment Plants in 1995. Analyses of discharge measurements indicate a mean downstream gain in discharge of 30 cubic feet per second along Salt Creek from Pioneers Boulevard, station 06803080, to station 06803523 downstream from the mouth of Stevens Creek, which was primarily contributed by the treatment plants. The mean gain per river mile along this stretch of Salt Creek was 2 cubic feet per second. The mean percent contribution of the wastewater-treatment plants to the flow of Salt Creek was 32 percent.
\end{abstract}

\section{INTRODUCTION}

The study area, which lies in the Salt Creek watershed, is located in Lancaster County, Nebraska, and is approximately 340 square miles $\left(\mathrm{mi}^{2}\right)$ in area. Salt Creek, a channelized creek, generally has a high salinity in many parts of its reach. The Dakota Formation, the primary local aquifer, has a high salinity in the study area
(Ellis, 1984). The City of Lincoln's Theresa Street and Northeast Wastewater Treatment Plants, located within the Lincoln city limits (fig. 1), discharge directly into Salt Creek. The discharge of Salt Creek is dominated by wastewater discharge downgradient from the wastewatertreatment plants during moderate- and low-flow conditions and dominated by stormwater runoff during large rain events. Other potential sources influencing the water quality of Salt Creek include agricultural, urban runoff, and other industrial discharges.

In 1994, the City of Lincoln requested that the U.S. Geological Survey (USGS) perform a study as part of the USGS Cooperative Program to support water-quality permitting decisions for the City of Lincoln's wastewater-treatment plants. The purpose of this report is to provide the City of Lincoln with streamflow and baseline water-quality data under moderate- to low-flow conditions. This study augments others done by the City of Lincoln in cooperation with other agencies and private consulting firms on Salt Creek's water-quality and effluent management. A plan was developed to collect discharge measurements and water-quality data during moderate- to low-flow conditions from Salt Creek and its tributaries.

\section{Approach and Methods}

Gaging stations were installed at (1) Salt Creek at Pioneers Boulevard, (2) Middle Creek at southwest 40th Street, (3) Haines branch at 


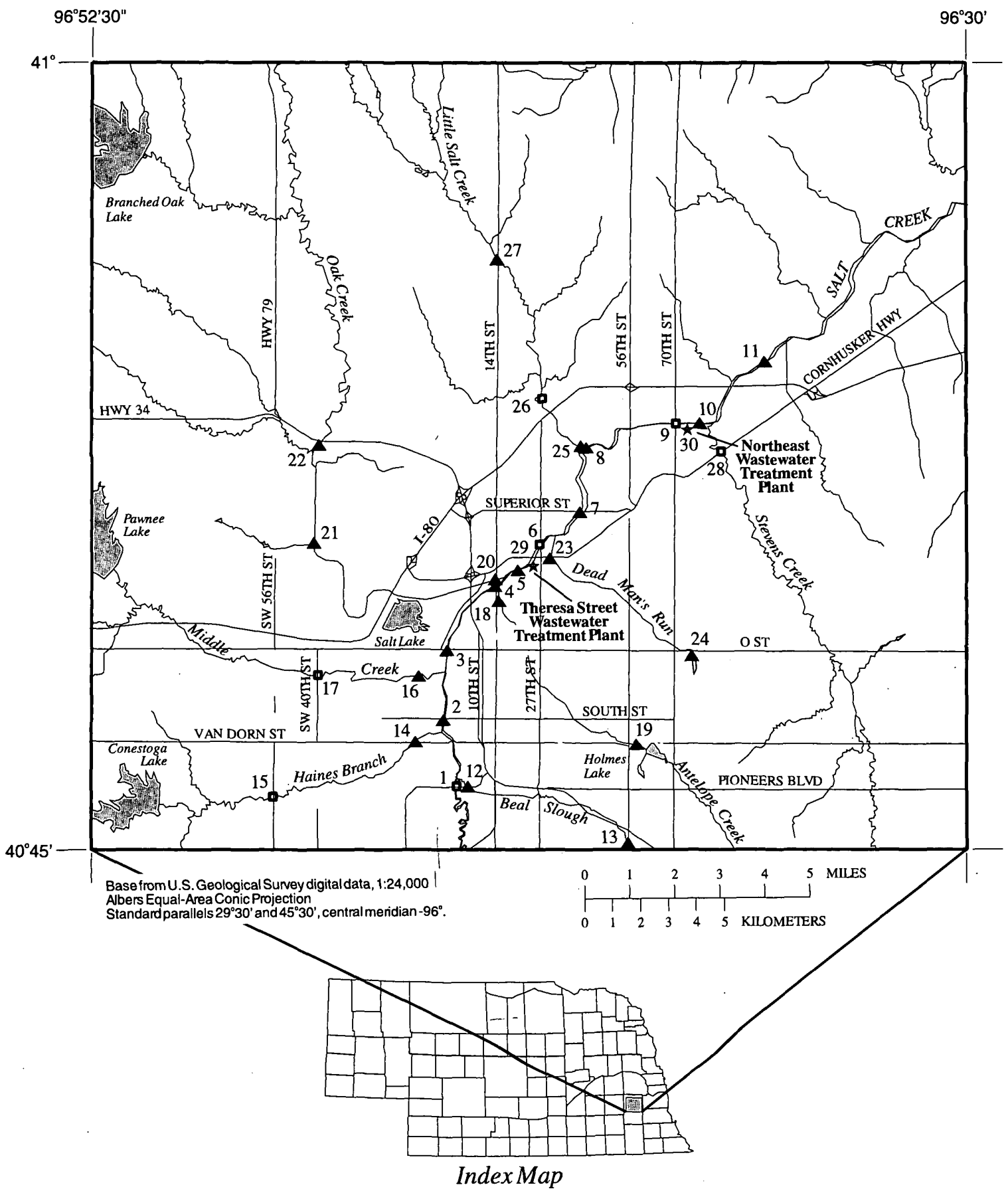

EXPLANATION
16 Sampling site and site location number
30* Wastewater-treatment plant and site location number
120 Sampling site and gaging station

Figure 1. Location of study area, sampling sites, gaging stations, and wastewater-treatment plants, Lincoln, Nebraska. 
southwest 56th Street, and (4) Salt Creek at 70th Street (fig. 1) in July and August 1994, and equipped with electronic data loggers for recording the stages and pressure transducers for sensing the stages. Existing gaging stations at Salt Creek at 27th Street, Little Salt Creek, and Stevens Creek (fig. 1), similarly equipped, also were used in the study.

Thirty sites were selected within the study area on the basis of existing discharge data, location of the wastewater-treatment plants, and location and contribution of flow of the tributaries (table 1). Four gain-and-loss investigations were conducted in 1994 and 1995 along a 13.78-mi reach of Salt Creek and along its tributaries at these sites. Discharge measurements taken at the 30 sites (fig. 1) generally were made on two or three subsequent days, specifically on June 20,1994, August 16 and 17, 1994, September 28 and 29, 1994, and August 28,29 , and 30,1995 . However, the investigation that began on June 20,1994, was discontinued on June 21, 1994, because of rainfall. During the last three gain-and-loss investigations, streamflow was measured during two subsequent days in accordance with procedures described by Rantz

Table 1. Listing of sampling sites on Salt Creek and tributaries near Lincoln, Nebraska, 1994-95

\begin{tabular}{|c|c|c|}
\hline $\begin{array}{l}\text { U.S. Geological } \\
\text { Survey site } \\
\text { identification number }\end{array}$ & $\begin{array}{c}\text { Site location } \\
\text { number } \\
\text { (fig. 1) }\end{array}$ & Site name \\
\hline 06803080 & 1 & Salt Creek at Pioneers Boulevard \\
\hline 06803082 & 13 & Beal Slough at 56th Street \\
\hline 06803085 & 12 & Beal Slough at Pioneers Boulevard \\
\hline 06803093 & 15 & Haines Branch at southwest 56th Street \\
\hline 06803097 & 14 & Haines Branch at Van Dorn Street \\
\hline 06803100 & 2 & Salt Creek at South Street \\
\hline 06803170 & 17 & Middle Creek at southwest 40th Street \\
\hline 06803182 & 16 & Middle Creek approximately 0.5 miles upstream from mouth \\
\hline 06803185 & 3 & Salt Creek at O Street \\
\hline 06803190 & 4 & Salt Creek at 14 th Street \\
\hline 068031985 & 19 & Antelope Creek at 56th Street \\
\hline 06803405 & 18 & Antelope Creek at Court Street \\
\hline 06803480 & 22 & Oak Creek at Highway 34 \\
\hline 06803487 & 21 & Oak Creek at closed bridge south of Air Park Road \\
\hline 06803493 & 20 & Oak Creek at 14th Street \\
\hline 06803495 & 5 & Salt Creek at Fairgrounds \\
\hline 06803496 & 29 & Theresa Street Wastewater Treatment Plant \\
\hline 06803500 & 6 & Salt Creek at 27 th Street \\
\hline 068035008 & 24 & Dead Man's Run at 70th Street \\
\hline 06803503 & 23 & Dead Man's Run at Cornhusker Highway \\
\hline 06803505 & 7 & Salt Creek at Superior Street \\
\hline 06803507 & 27 & Little Salt Creek at 14th Street \\
\hline 06803510 & 26 & Little Salt Creek at 27th Street \\
\hline 068035108 & 25 & Little Salt Creek near mouth (marsh) \\
\hline 06803511 & 8 & Salt Creek at (former) landfill near Little Salt Creek \\
\hline 06803513 & 9 & Salt Creek at 70 th Street \\
\hline 068035135 & 30 & Northeast Wastewater Treatment Plant \\
\hline 06803514 & 10 & Salt Creek below Northeast Wastewater Treatment Plant \\
\hline 06803523 & 28. & Stevens Creek at Highway 6 \\
\hline 06803525 & 11 & Salt Creek below Stevens Creek at Waverly \\
\hline
\end{tabular}


(1982). The last measurement of the first day, at the Salt Creek at Fairgrounds site, was repeated the second day. Measurements were taken in a downstream direction in accordance with the Lagrangian flow principle.

Continuous records of stage were obtained from electronic data loggers or from digital recorders that punch stage values on paper tapes at selected time intervals. Methods of discharge measurements are described by Rantz (1982). In computing discharge records, results of measurement are plotted against stage values and stage-discharge relation curves are constructed. From these curves, rating tables are developed that indicate discharge at any given stage.

Field measurements were taken at all sites for $\mathrm{pH}$, dissolved oxygen, temperature of air and water, and specific conductance. Water-quality samples were collected from 11 sites along Salt Creek in 1994 (only 4 sites in June 1994) and at all 30 sites in 1995 . The water-quality data include nutrients (total and dissolved) and major ions. The results allowed determination of gain-andloss characteristics under moderate- to low-flow conditions and selected water-quality reductions or contributions by the wastewater-treatment plants, tributaries, and ground water on the water quality of Salt Creek.

Methods for collecting surface-waterquality data are described in Wells and others (1990). Samples were collected using a depthintegrated, equal-width increment method (EWI) that was reduced to a grab sample when the stream width was less than $2 \mathrm{ft}$. The EWI method, in which samples are collected at centroids of equal-width increments, normally is used in shallow streams where the distribution of discharge in the cross section is not uniform or in streams where the distribution of water discharge in the cross section is unknown. Samples were collected by USGS personnel with a US D-77 cap and nozzle, 5/16-inch nozzle, quart bottle, and wading rod using a US DH-81 adapter. Specific conductance, $\mathrm{pH}$, water temperature, and dissolved oxygen were measured in the field at all sites with portable meters on an aliquot of the composite stream sample in accordance with procedures described by Fishman and Friedman (1989).
Water samples were collected from the sites along Salt Creek on June 20, 1994, August 16 and 17, 1994, and September 28 and 29, 1994. In addition, water samples were collected from all 30 sites along Salt Creek and its tributaries on August 28, 29, and 30, 1995. Quality-assurance samples consisting of one equipment blank and one duplicate were collected at Salt Creek at 27th Street or Salt Creek at Fairgrounds on August 16 and 17, 1994, and September 28 and 29, 1994, and August 28 and 29, 1995. Samples were put in brown polyethylene and glass bottles and chilled with ice. Samples were treated onsite when filtering was not required. The remainder of the samples were filtered and treated at the local USGS laboratory in Lincoln, Nebraska, within 1 hour of sample collection and were kept chilled at 4 degrees Celsius prior to mailing of the samples to the USGS National Water-Quality Laboratory (NWQL) in Arvada, Colorado. Analyses were completed within 7 days of receipt by the Arvada laboratory. Water-quality constituents analyzed included total residue and residue at 180 degrees Celsius, dissolved solids, alkalinity, oil and grease, total and dissolved nutrients, and dissolved major ions. Analyses were done in accordance with standard methods described by Fishman and Friedman (1989).

Stream loads were calculated for nutrients and major ions by multiplying the discharge by the concentration of the constituent and a unit correction factor. Gains and losses of loads also were calculated. Loads were corrected for inputs from the wastewater-treatment plants and tributaries for the samples collected on August 28, 29, and 30, 1995.

\section{Acknowledgments}

The author thanks the City of Lincoln and the Lower Platte South Natural Resources District for their assistance in the field with sampling and for permitting access to the sampling sites. 


\section{GAIN-AND-LOSS MEASUREMENTS OF SALT CREEK AND ITS TRIBUTARIES}

Discharge of Salt Creek is affected by the discharge of its tributaries, which, in turn, are affected by releases from Conestoga, Pawnee, Branched Oak, and Holmes Lakes, among others. The wastewater-treatment plants of the City of Lincoln also may affect the streamflow of Salt Creek. Currently there are no regulatory discharge requirements for these wastewatertreatment plants. The water received by the wastewater-treatment plants is derived from the City of Lincoln Well Field near Ashland, Nebraska. Peak discharge generally occurs around 10:00 a.m. each day. Discharge of both wastewater-treatment plants on the sampling dates are shown in figure 2 (Lyle R. Christensen, City of Lincoln, written commun., 1995).

Three sets of streamflow gain-and-loss measurements were made during 1994 and 1995 at 28 sites along a 13.78-mile reach of Salt Creek and its tributaries (fig. 1). A schematic diagram indicating river miles is shown in figure 3 . The Salt Creek reach extends from Pioneers Boulevard to a site downstream from Stevens Creek. The hydrographs for the sampling period for the Salt Creek at Pioneers Boulevard, Haines Branch, Middle Creek, Salt Creek at 27th Street, Little Salt Creek, Salt Creek at 70th Street, and Stevens Creek gaging stations, as well as precipitation at the Lincoln Municipal Airport precipitation station, are shown in figures 4 through 6. Streamflow data for Salt Creek and its tributaries are presented in table 2. A flow-duration graph for Salt Creek at 27th Street is presented in figure 7 . In general, measurements were made and samples were collected at flows near or slightly greater than the median. Figure 8 shows the relative contributions of the wastewatertreatment plants and the tributaries to the streamflow of Salt Creek.

Flow measurements at the sampling sites during each sample event are shown in figures 9 through 12. Figure 13 shows the mean flow measurement at the sampling sites of the last three sample events. Measured gains for the total reach ranged from approximately 20 cubic feet per second $\left(\mathrm{ft}^{3} / \mathrm{s}\right)$ on September 28 and 29, 1994, to $38 \mathrm{ft}^{3} / \mathrm{s}$ on August 28, 29, and 30, 1995 (table 3).
The mean gain for the total reach was $30 \mathrm{ft}^{3} / \mathrm{s}$ (table 3). This reach gained water with an average of $2 \mathrm{ft}^{3} / \mathrm{s}$ per river mile (table 4 ). A schematic diagram of mean gains and losses of streamflow per segment of Salt Creek is shown in figure 14. Mean gains and losses per segment of Salt Creek as well as per river mile are shown in figure 15.

\section{WATER-QUALITY DATA OF SALT CREEK AND ITS TRIBUTARIES}

Water-quality data and constituent load estimates are included in this report in tabular and graphic form (tables 5 through 7 at the back of the report and figures 16 through 20). The method reporting level was used in the load calculations when actual concentrations were less than the detection limit. Concentrations of dissolved solids, specific conductance, total ammonia and organics, total phosphorus, and dissolved chloride concentrations in samples collected from Salt Creek, its tributaries, and the Theresa Street and Northeast Wastewater Treatment Plants on August 28, 29, and 30, 1995, are shown in figures 16 through 20 . Concentration of salts increased from a location near Salt Creek at O Street to below Stevens Creek (figs. 16, 17, and 20). Quality-assurance samples revealed that the water-quality results of duplicates were very similar and that blanks remained uncontaminated in the field and laboratory.

The load of selected constituents along the investigated reach of Salt Creek is affected by the load contributed by the tributaries, wastewatertreatment plants, and ground water, as well as the load already present at Salt Creek at Pioneers Boulevard, the most upstream sampling site. Percent contributions of flow and selected constituents detected in water from the wastewater-treatment plants, tributaries, and ground water are presented in table 8 . The percentage of the load contributed by the wastewater plants was calculated as the sum of the load of both plants divided by the load of Salt Creek below Stevens Creek, less the load of Salt Creek at Pioneers Boulevard. Percentage of the load contributed by selected constituents from 

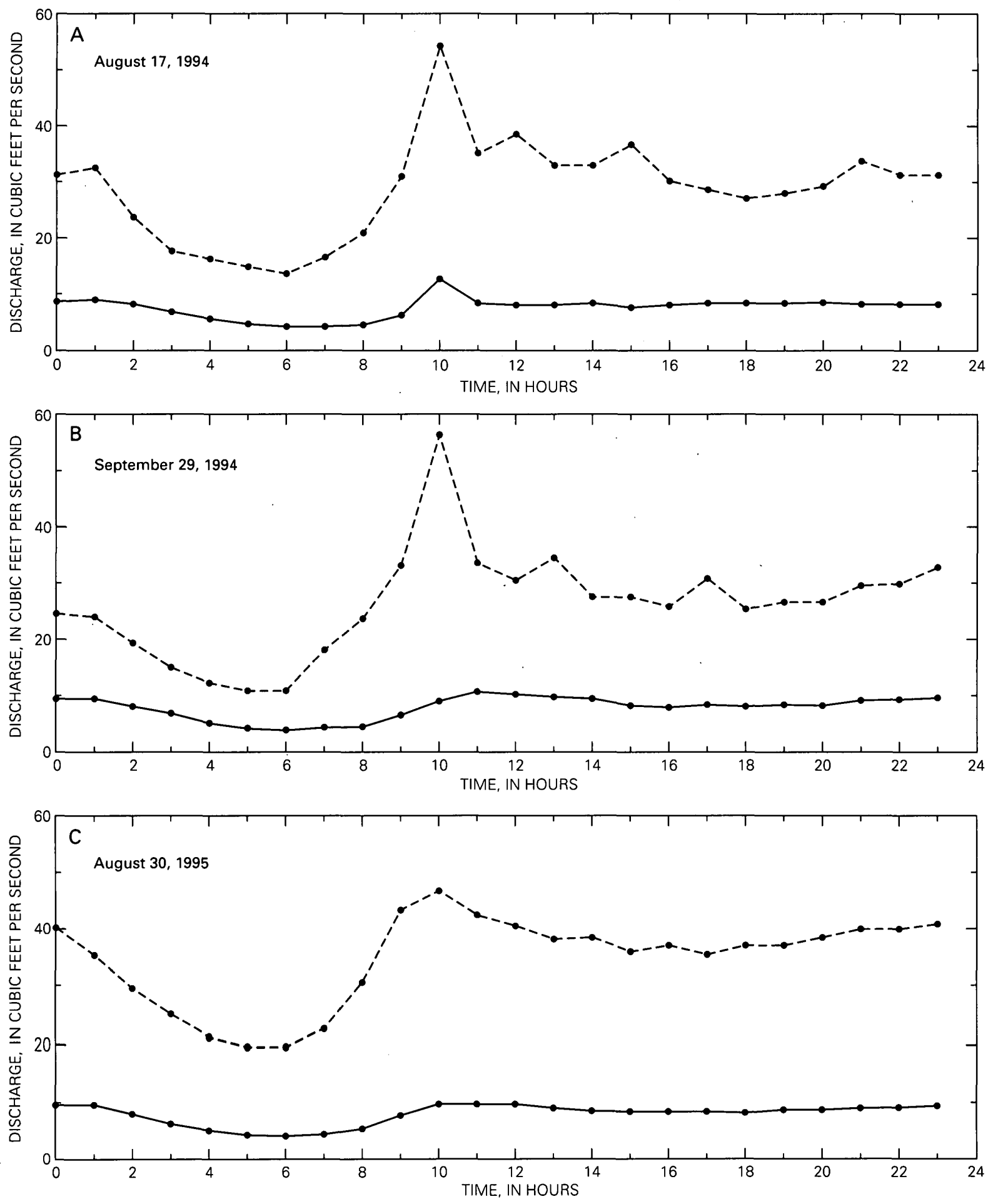

EXPLANATION

- - - - - Theresa Street Wastewater Treatment Plant

$\longrightarrow$ Northeast Wastewater Treatment Plant

Figure 2. Discharge of the Theresa Street and Northeast Wastewater Treatment Plants of City of Lincoln, Nebraska, on (A) August 17, 1994, (B) September 29, 1994, and (C) August 30, 1995 (Lyle R. Christensen, City of Lincoln, written commun., 1995). 


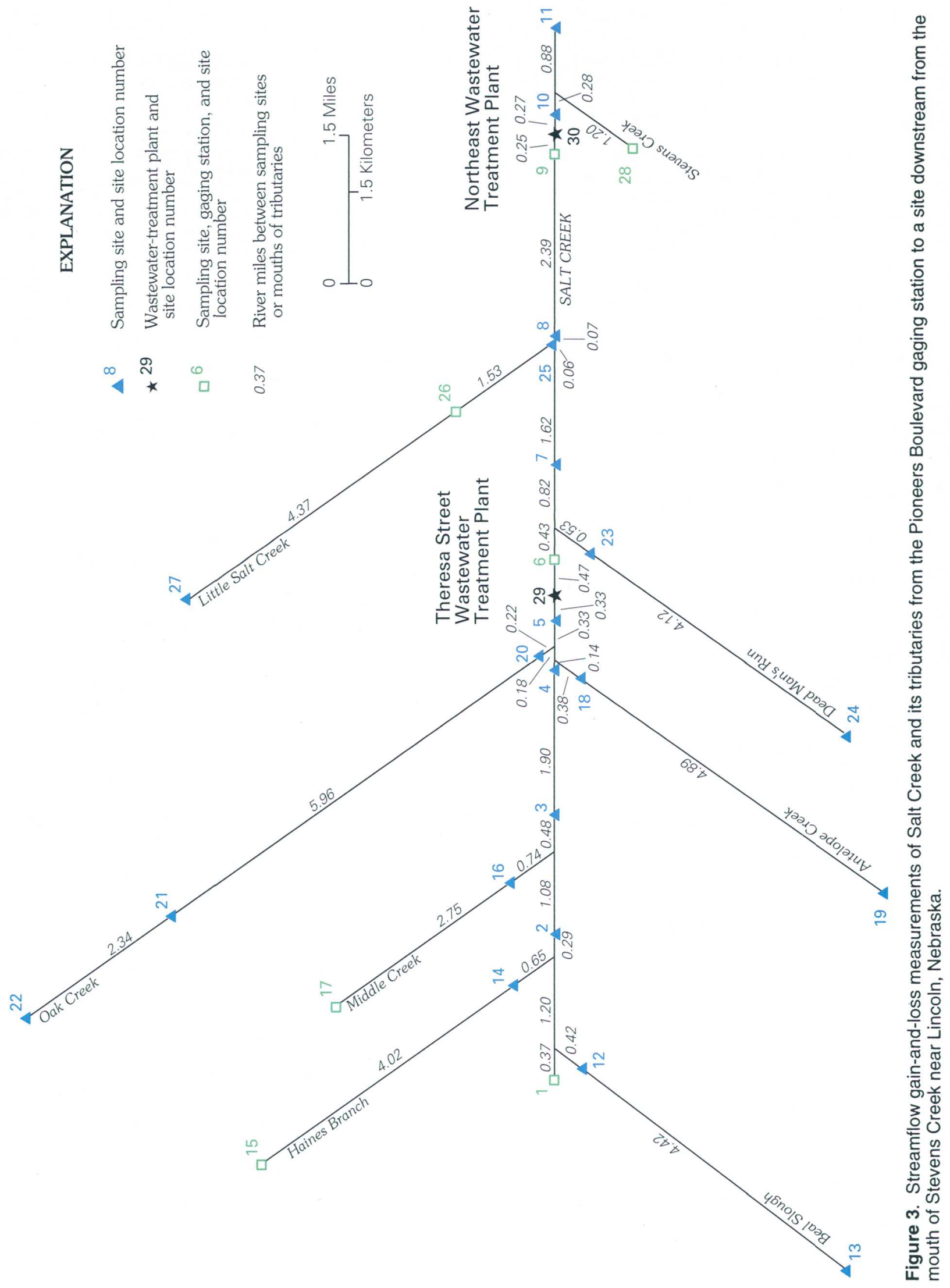


Table 2. Flow measurements of Salt Creek, its tributaries, and the Theresa Street and Northeast Wastewater Treatment Plants, Lincoln, Nebraska, June 20, 1994, August 16-17, 1994, September 28-29, 1994, and August 28-30, 1995

$[--$, no data]

\begin{tabular}{|c|c|c|c|c|c|c|}
\hline \multirow[b]{2}{*}{$\begin{array}{l}\text { U.S. Geological Survey site } \\
\text { identification number }\end{array}$} & \multirow[b]{2}{*}{$\begin{array}{l}\text { Site location } \\
\text { number } \\
\text { (fig. 1) }\end{array}$} & \multicolumn{5}{|c|}{ Discharge, in cubic feet per second } \\
\hline & & June 20, 1994 & $\begin{array}{c}\text { August 16-17, } \\
1994\end{array}$ & $\begin{array}{l}\text { September 28- } \\
29,1994\end{array}$ & $\begin{array}{l}\text { August 28-30, } \\
1995\end{array}$ & $\begin{array}{c}\text { Mean, not } \\
\text { including the } \\
\text { June 20, } \\
1994 \text {, } \\
\text { measure- } \\
\text { ment }\end{array}$ \\
\hline 06803080 & 1 & 34 & 15 & 15 & 13 & 14 \\
\hline 06803082 & 13 & .70 & .25 & .37 & .24 & .29 \\
\hline 06803085 & 12 & .77 & .50 & .72 & .53 & 0.58 \\
\hline 06803093 & 15 & 4.1 & 1.8 & 1.4 & 1.9 & 1.7 \\
\hline 06803097 & 14 & 7.4 & 5.2 & 3.7 & 4.6 & 4.5 \\
\hline 06803100 & 2 & 46 & 23 & 22 & 21 & 22 \\
\hline 06803170 & 17 & 3.9 & 3.6 & 1.9 & 3.2 & 2.9 \\
\hline 06803182 & 16 & 6.3 & 5.2 & 3.8 & 3.8 & 4.3 \\
\hline 06803185 & 3 & 54 & 33 & 29 & 27 & 30 \\
\hline 06803190 & 4 & 56 & 37 & 33 & 32 & 34 \\
\hline 068031985 & 19 & .29 & .08 & .57 & .11 & .25 \\
\hline 06803405 & 18 & 1.9 & 1.6 & 2.6 & 2.0 & 2.0 \\
\hline 06803480 & 22 & 77 & 33 & 16 & 18 & 22 \\
\hline 06803487 & 21 & 82 & 35 & 18 & 19 & 24 \\
\hline 06803493 & 20 & 106 & 41 & 23 & 19 & 28 \\
\hline $\begin{array}{l}06803495 \\
\text { (first day of sampling event) }\end{array}$ & 5 & 170 & 82 & 59 & 55 & 65 \\
\hline $\begin{array}{c}06803495 \\
\text { (second day of sampling event) }\end{array}$ & 5 & -- & 72 & 55 & 48 & 58 \\
\hline 06803496 & 29 & -- & 26 & 34 & 22 & 27 \\
\hline 06803500 & 6 & -- & 103 & 99 & 68 & 90 \\
\hline 068035008 & 24 & -- & .17 & .15 & .13 & .15 \\
\hline 06803503 & 23 & -- & 1.2 & .78 & 1.3 & 1.1 \\
\hline 06803505 & 7 & -- & 98 & 91 & 85 & 91 \\
\hline 06803507 & 27 & -- & 1.9 & 1.2 & .60 & 1.2 \\
\hline 06803510 & 26 & -- & 4.7 & 3.6 & 2.5 & 3.6 \\
\hline 068035108 & 25 & -. & 5.2 & 4.1 & 3.0 & 4.1 \\
\hline 06803511 & 8 & -- & 110 & 104 & 100 & 105 \\
\hline 06803513 & 9 & -- & 120 & 108 & 90 & 106 \\
\hline 068035135 & 30 & -- & 8.0 & 10 & 9.0 & 9.0 \\
\hline 06803514 & 10 & -- & 125 & 113 & 110 & 116 \\
\hline 06803523 & 28 & -- & 4.4 & 3.6 & 2.8 & 3.6 \\
\hline 06803525 & 11 & -- & 136 & 117 & 112 & 122 \\
\hline
\end{tabular}


tributaries was calculated as the sum of loads of all tributaries divided by the load of Salt Creek below Stevens Creek, less the load of Salt Creek at Pioneers Boulevard. Percentage of the load contributed by ground water within the reach was calculated as the load of Salt Creek below Stevens Creek reduced by the loads of the tributaries and Salt Creek at Pioneers Boulevard, divided by load of Salt Creek below Stevens Creek, less the load of Salt Creek at Pioneers Boulevard. Losses due to chemical or physical processes were assumed to be zero in these calculations.

The mean percent contribution of the wastewater-treatment plants to the flow of Salt Creek was 32 percent. Similarly, the relative mean contribution of the tributaries and ground water to the flow of Salt Creek were 41 percent and 26 percent, respectively (table 8 ). Gains and losses presented in tables 9 and 10 were calculated without considering the contributions of the wastewater-treatment plants and the tributaries because water-quality samples from these sites were not collected in 1994. The contribution of the wastewater-treatment plants and tributaries was considered in the determination of gains and losses of selected constituents along Salt Creek.

\section{SUMMARY}

A 2-year study was completed to document streamflow gain and loss and to estimate loads of selected constituents in a reach of Salt Creek and its tributaries near Lincoln, Nebraska. Discharge and water-quality data were collected. Four gain-and-loss investigations were conducted in 1994 and 1995 during moderate- to low-flow conditions at 28 sites along a 13.78-mile reach of Salt Creek and along its tributaries. Waterquality samples were collected from 11 sites (4 sites in June 1994) along Salt Creek in 1994 and from 28 sites along Salt Creek and its tributaries and the Theresa Street and Northeast Wastewater Treatment Plants in 1995.

Flow measurements show a mean downstream gain in discharge of 30 cubic feet per second along Salt Creek from Pioneers Boulevard (station 06803080) to downstream from the mouth of Stevens Creek (station 06803523). The mean gain per river mile along this stretch of Salt Creek was 2 cubic feet per second. The mean percent contribution of the wastewater-treatment plants to the flow of Salt Creek was 32 percent, and the relative mean contributions of the tributaries and ground water to the flow of Salt Creek were 41 percent and 26 percent, respectively.

\section{REFERENCES}

Ellis, M.J., 1984, Overview of the Dakota aquifer system in Nebraska, in Jorgensen, D.G., Signor, D.C., eds., Geohydrology of the Dakota aquifer-Proceedings of the First C.V. Theis Conference on Geohydrology: Worthington, Ohio, National Water Well Association, p. $48-55$.

Fishman, M.J., and Friedman, L.C., eds., 1989, Methods for determination of inorganic substances in water and fluvial sediments: U.S. Geological Survey Techniques of Water-Resources Investigations, book 5, chap. A1, $545 \mathrm{p}$.

Minges, D.R., 1983, Selected hydrologic characteristics of the South Platte River in the vicinity of the proposed Narrows Reservoir near Fort Morgan, Colorado: U.S. Geological Survey Water-Resources Investigations Report 82-4071, 25 p.

Rantz, S.E., 1982, Measurement and computation of streamflow-Volume 1. Measurement of stage and discharge: U.S. Geological Survey Water-Supply Paper 2175, $284 \mathrm{p}$.

Wells, F.C., Gibbons, W.J., and Dorsey, M.E., 1990, Guidelines for collection and field analysis of waterquality samples from streams in Texas: U.S. Geological Survey Open-File Report 90-127, 79 p. 


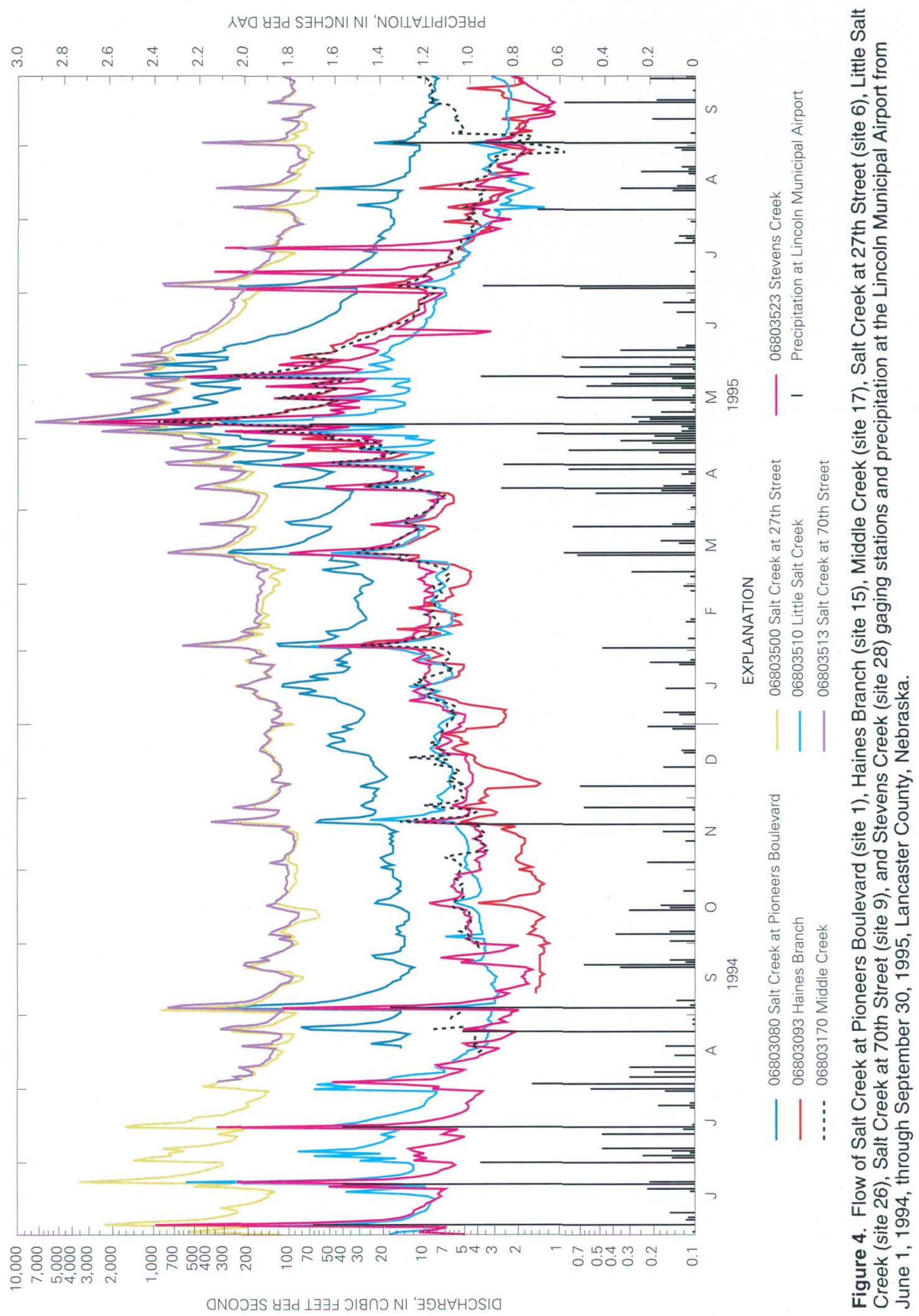




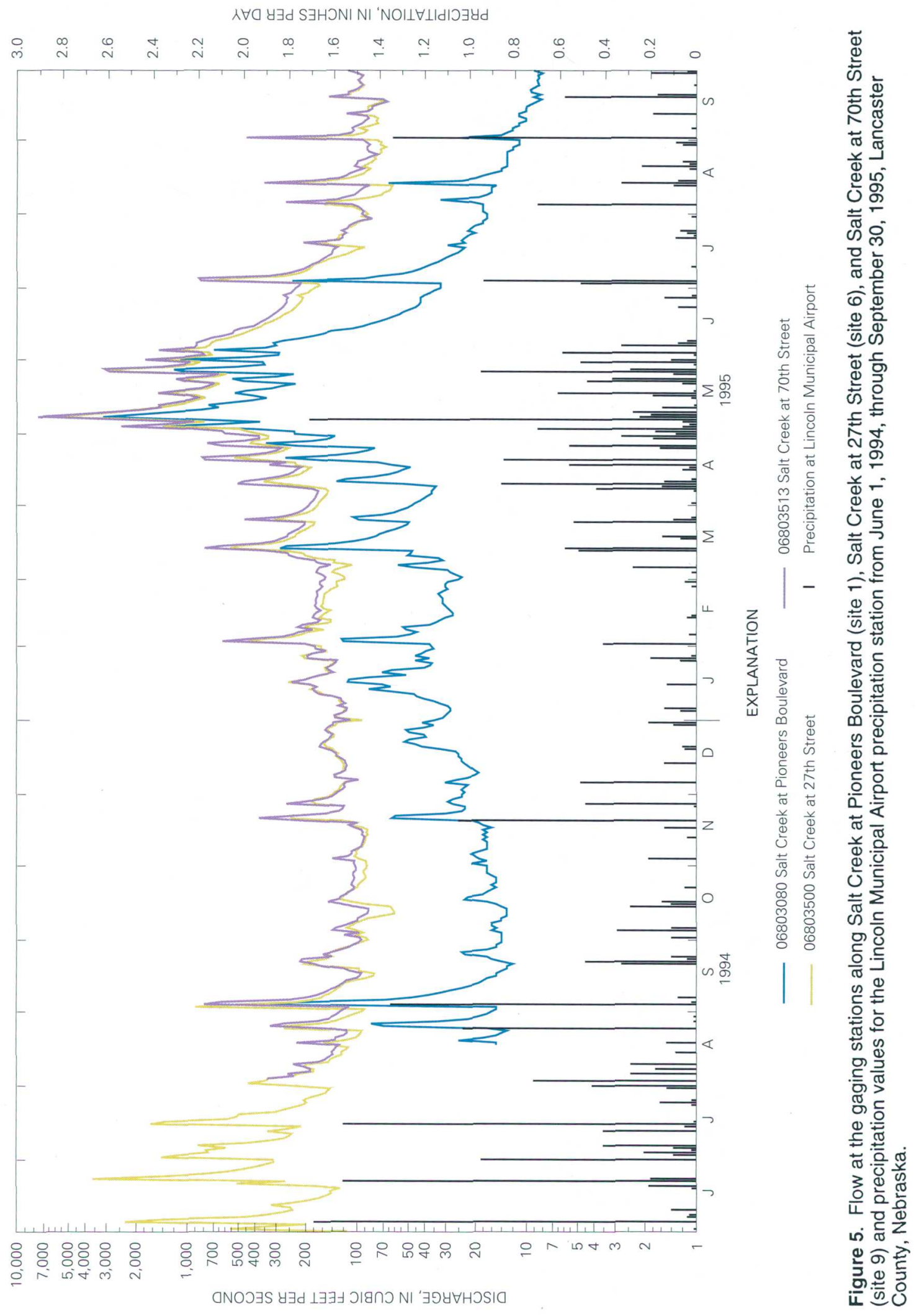


$\wedge \forall O \forall \exists d$ S $\exists H O N I N I$ 'NOIL $\forall \perp I d I O \exists y d$

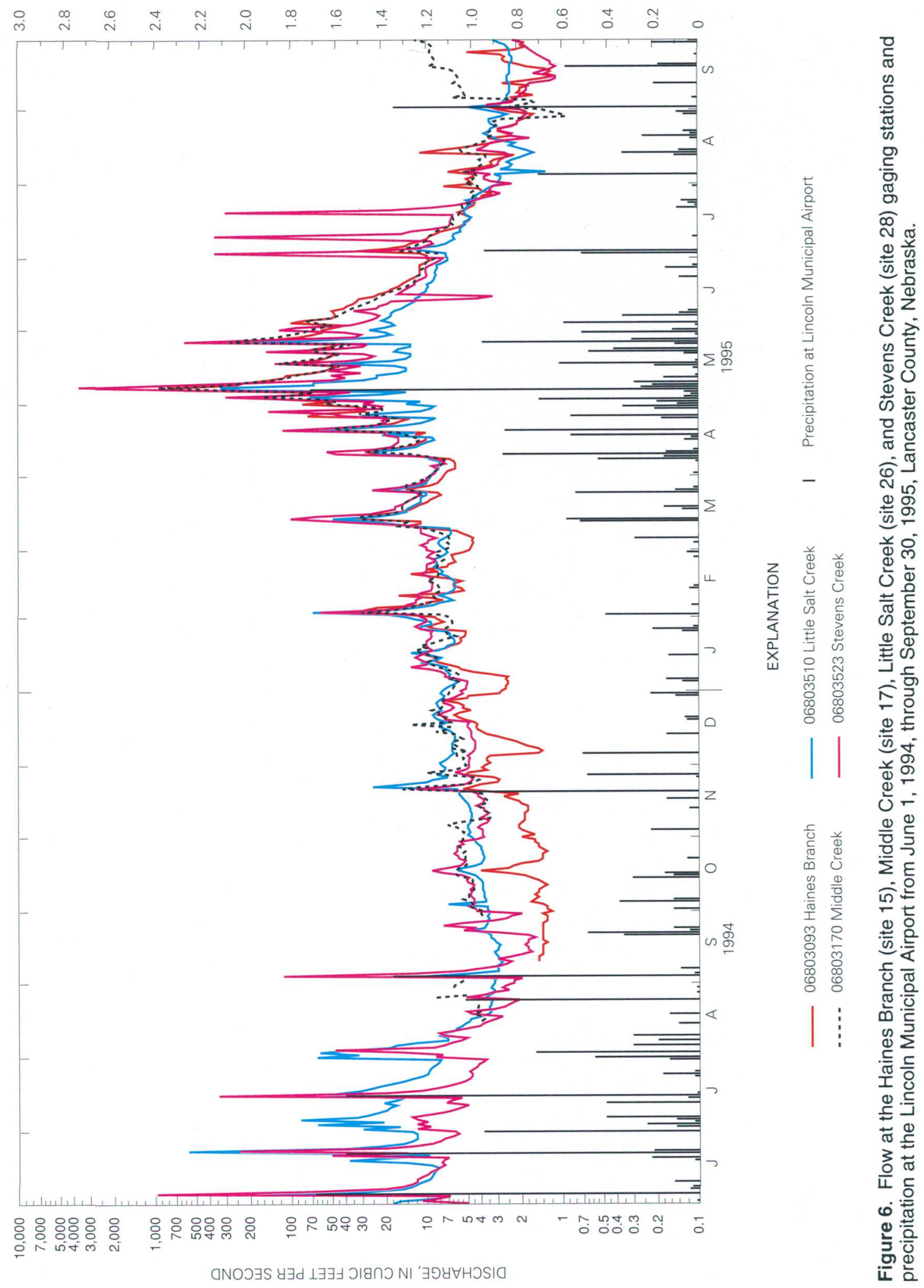




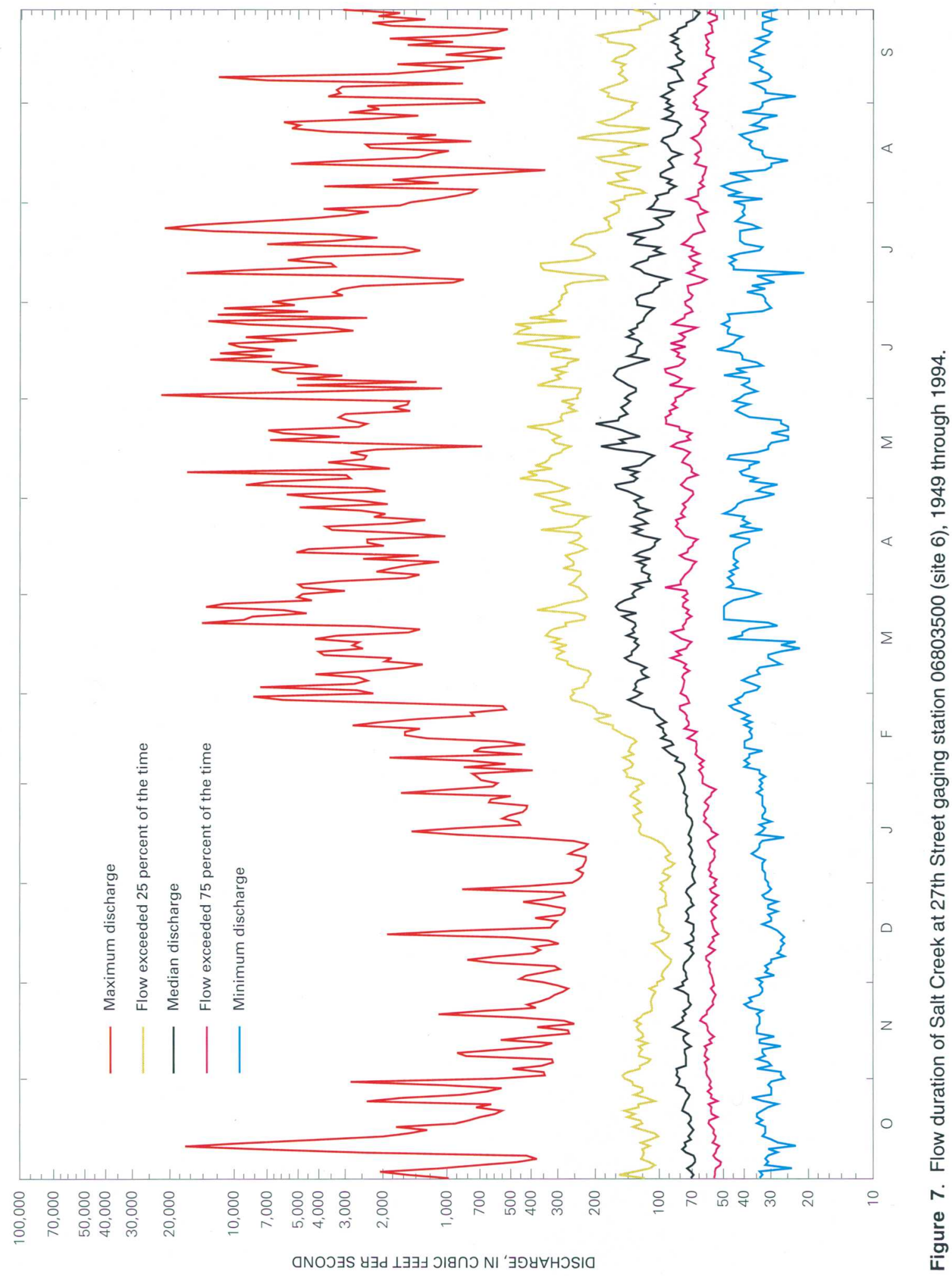



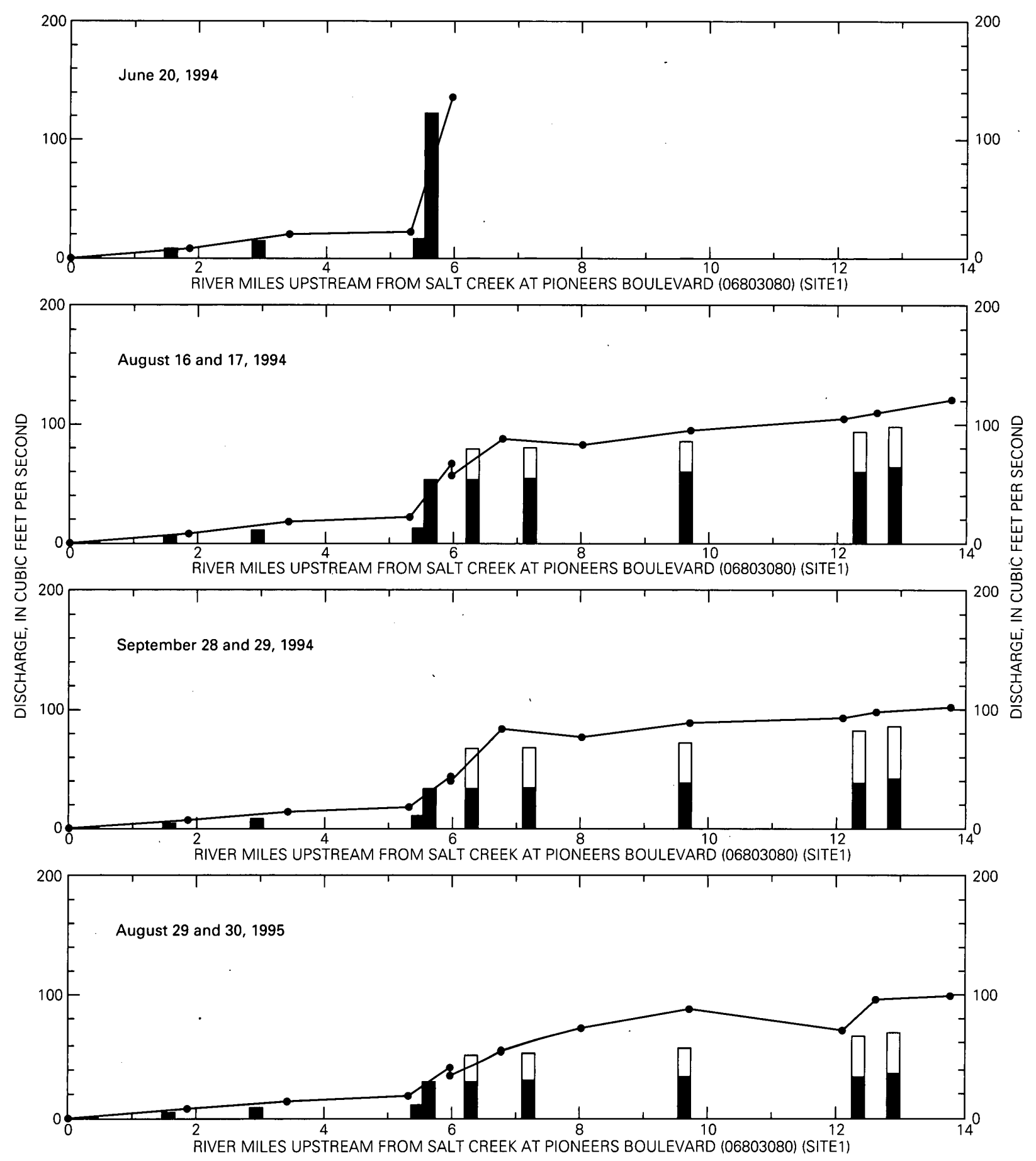

EXPLANATION

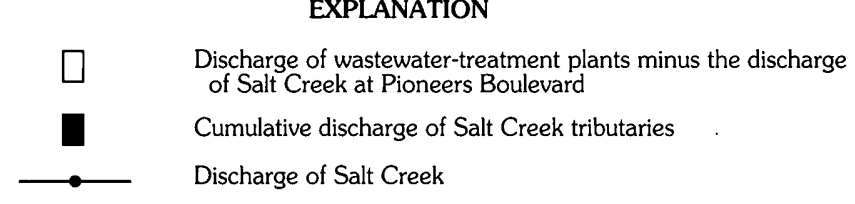

Figure 8. Flow measurements of Salt Creek, its tributaries, and the Theresa Street and Northeast Wastewater Treatment Plants, Lincoln, Nebraska, June 20, 1994, August 16-17, 1994, September 28-29, 1994, and August 2830, 1995. 


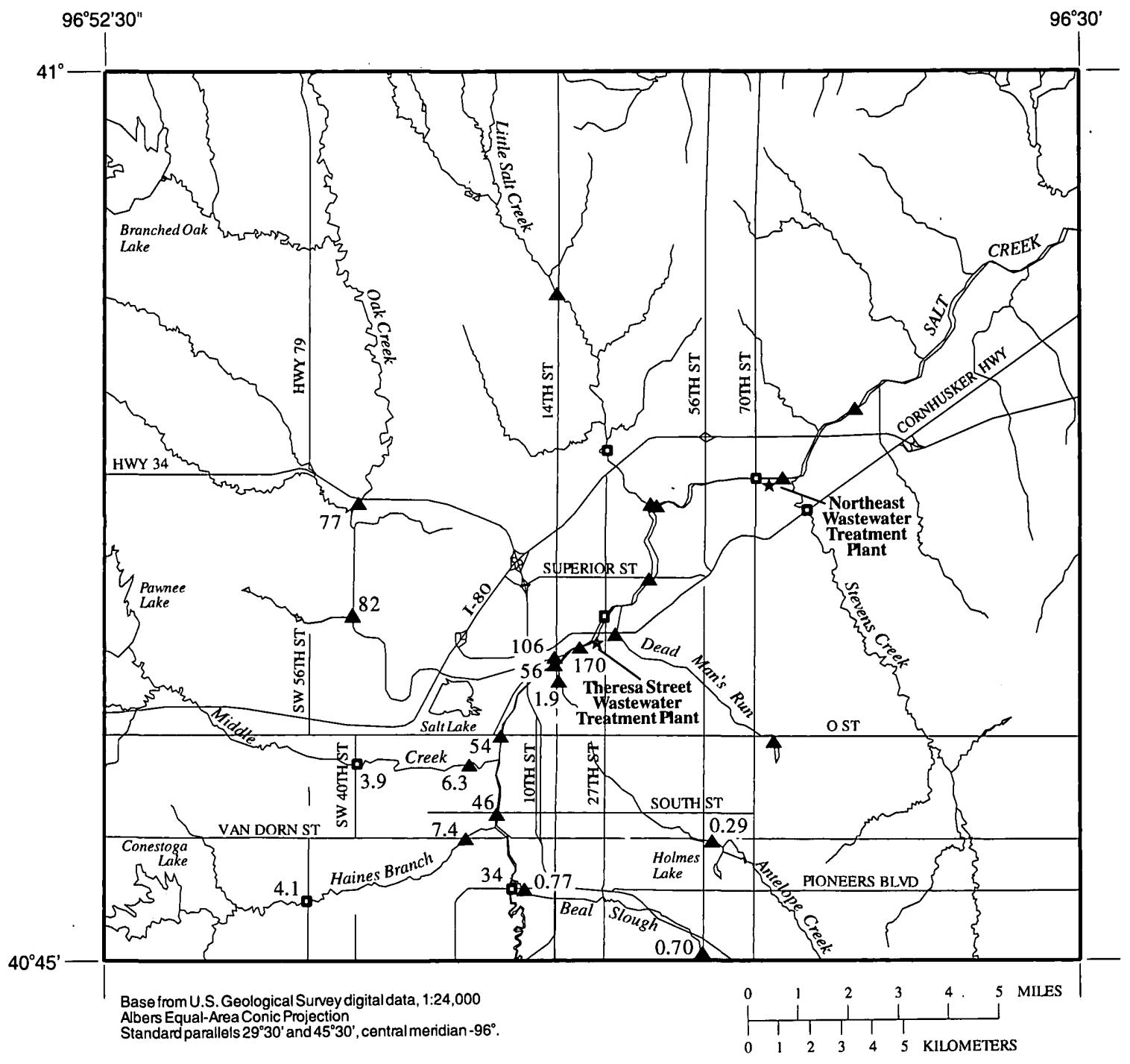

EXPLANATION

A Sampling site

* Wastewater-treatment plant

- Sampling site and gaging station

3.9 Discharge, in cubic feet per second

Figure 9. Flow measurements at sampling sites on Salt Creek, its tributaries, and the Theresa Street and Northeast Wastewater Treatment Plants, Lincoln, Nebraska, June 20, 1994. 


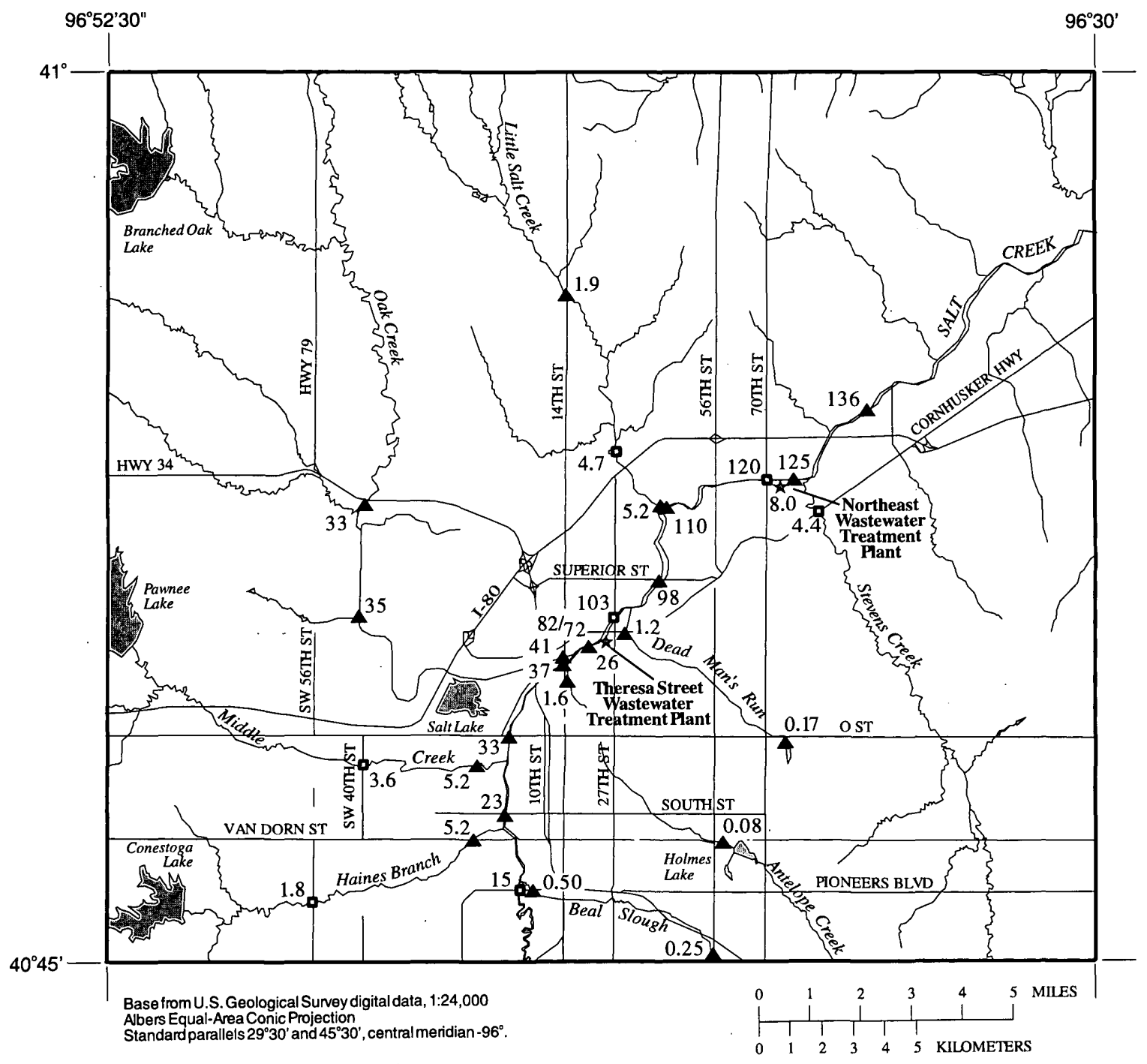

EXPLANATION

A Sampling site

$\star$ Wastewater-treatment plant

- Sampling site and gaging station

3.9 Discharge measurement, in cubic feet per second

$82 / 72$ Multiple discharge measurements, in cubic feet per second

Figure 10. Flow measurements at sampling sites on Salt Creek, its tributaries, and the Theresa Street and Northeast Wastewater Treatment Plants, Lincoln, Nebraska, August 16-17, 1994. 


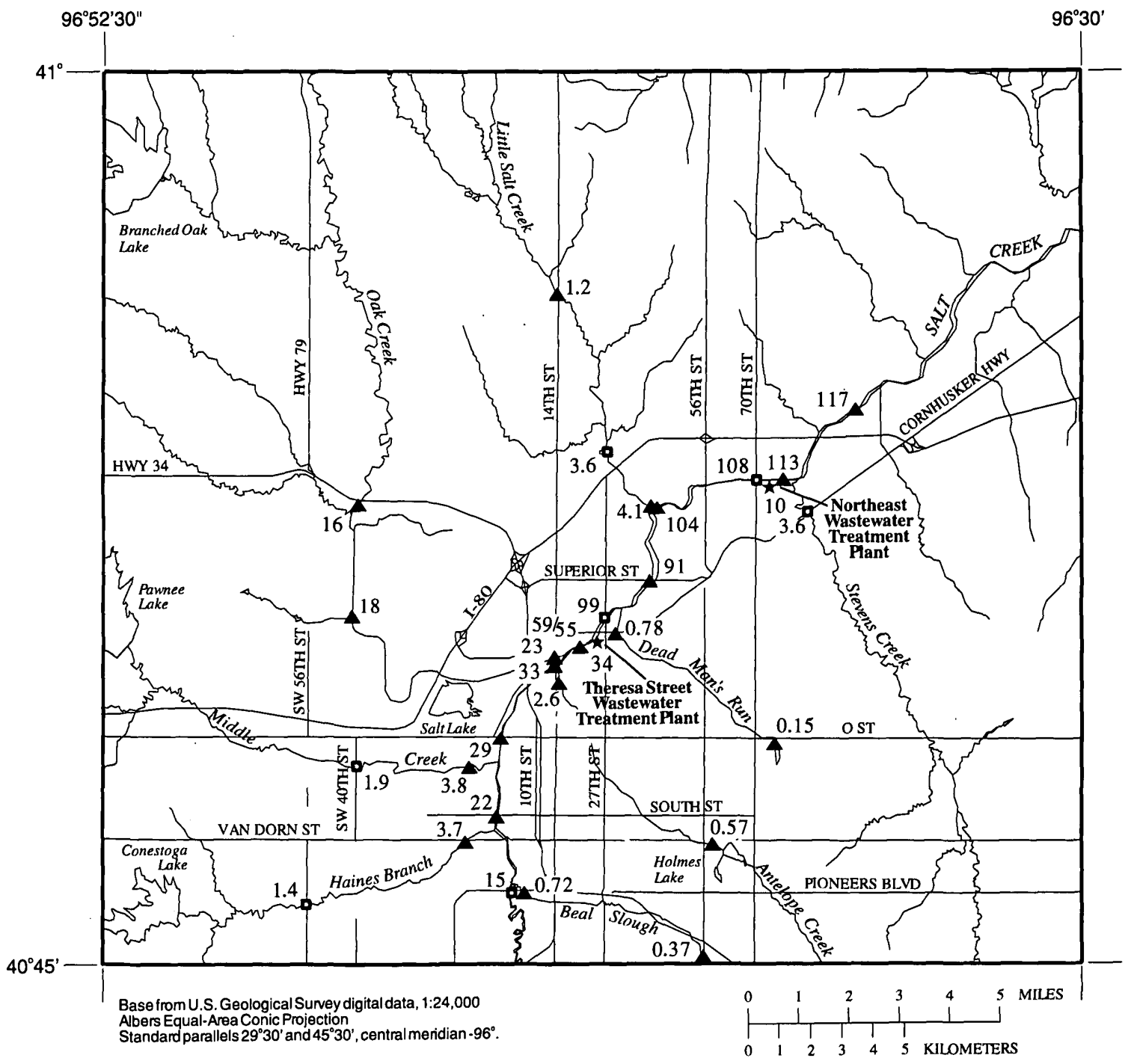

\section{EXPLANATION}

- Sampling site

$\star$ Wastewater-treatment plant

- Sampling site and gaging station

3.9 Discharge measurement, in cubic feet per second

$59 / 55$ Multiple discharge measurements, in cubic feet per second

Figure 11. Flow measurements at sampling sites on Salt Creek, its tributaries, and the Theresa Street and Northeast Wastewater Treatment Plants, Lincoln, Nebraska, September 28-29, 1994. 


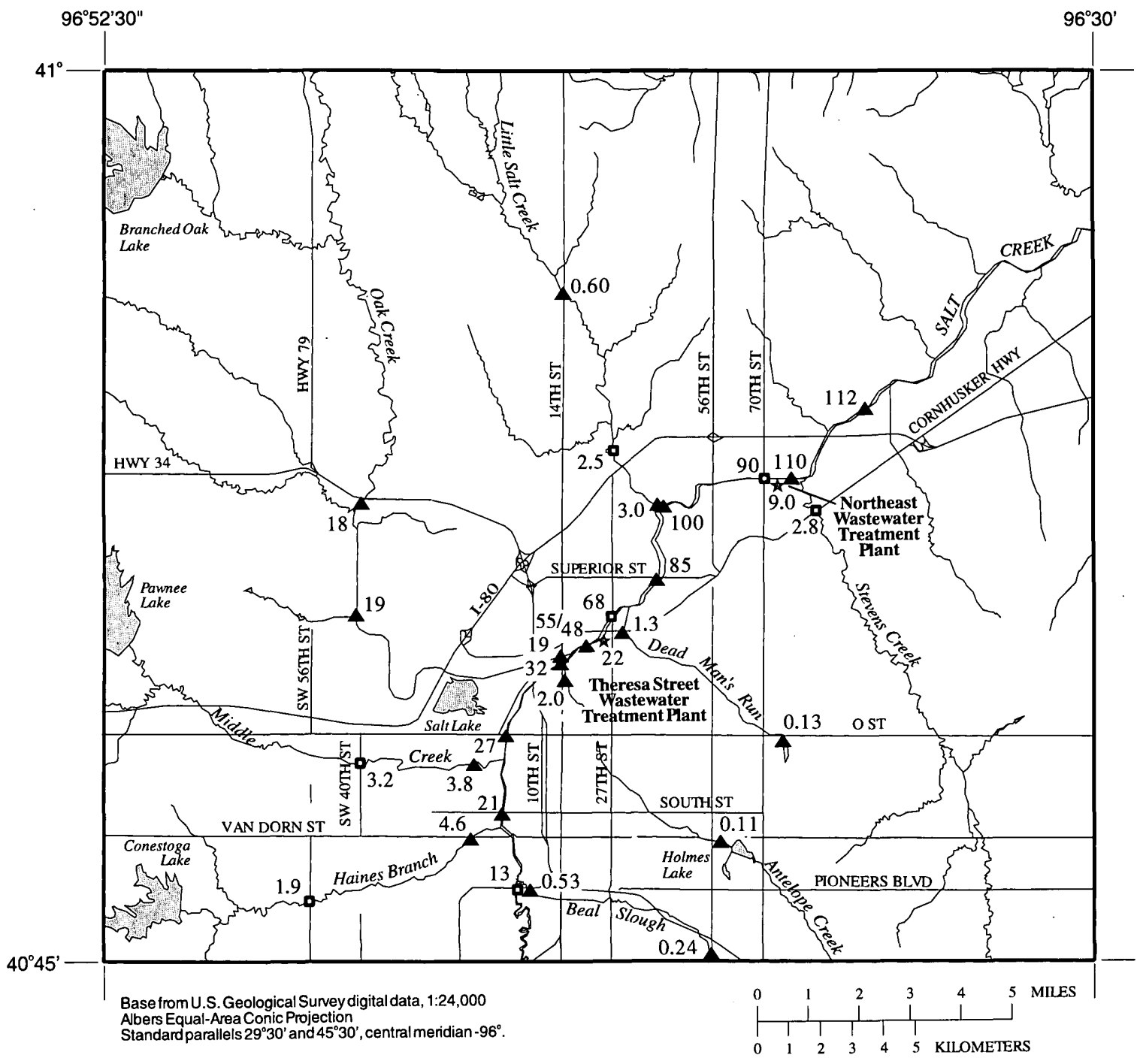

EXPLANATION
A Sampling site
* Wastewater-treatment plant
- Sampling site and gaging station
3.9 Discharge measurement, in cubic feet per second
$55 / 48$ Multiple discharge measurements, in cubic feet

Figure 12. Flow measurements at sampling sites on Salt Creek, its tributaries, and the Theresa Street and Northeast Wastewater Treatment Plants, Lincoln, Nebraska, August 28-30, 1995. 


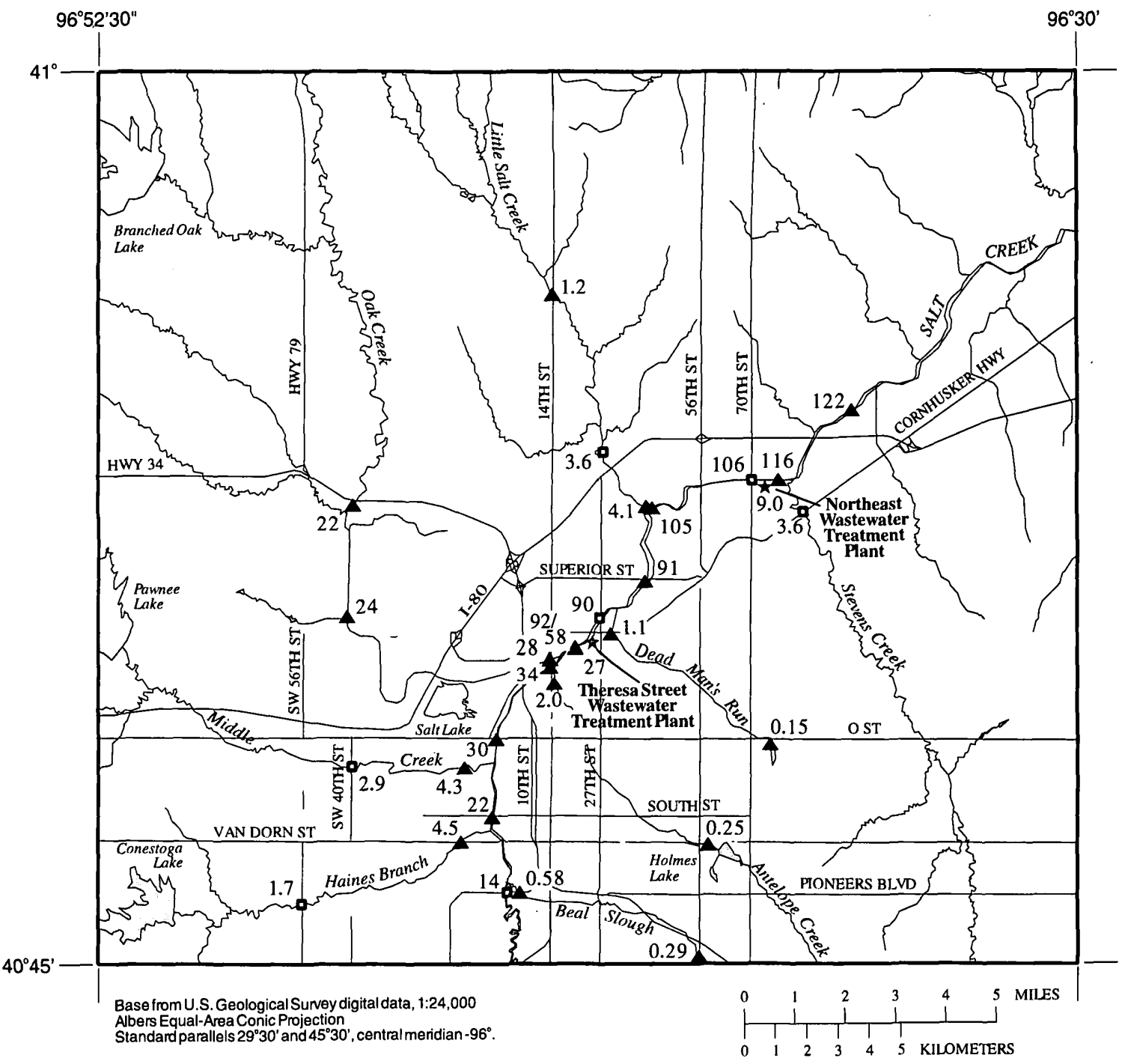

EXPLANATION
- Sampling site
^ Wastewater-treatment plant
- Sampling site and gaging station
3.9 Discharge measurement, in cubic feet per second

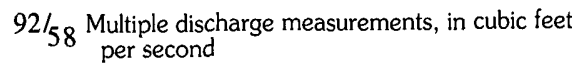

Figure 13. Mean flow measurements of Salt Creek, its tributaries, and the Theresa Street and Northeast Wastewater Treatment Plants, Lincoln, Nebraska, June 20, 1994, August 16-17, 1994, September 28-29, 1994, and August 28-30, 1995. 
Table 3. Discharge gain-and-loss measurements along Salt Creek near Lincoln, Nebraska, June 20, 1994, August 16-17, 1994, September 28-29, 1994, and August 28-30, 1995

$[--$, no data $]$

\begin{tabular}{|c|c|c|c|c|c|}
\hline \multirow[b]{2}{*}{ Stream reach } & \multicolumn{5}{|c|}{ Discharge, in cubic feet per second } \\
\hline & June 20, 1994 & $\begin{array}{c}\text { August 16-17, } \\
1994\end{array}$ & $\begin{array}{c}\text { September 28- } \\
29,1994\end{array}$ & $\begin{array}{c}\text { August 28-30, } \\
1995\end{array}$ & Mean \\
\hline $1-2$ & 4 & 2 & 3 & 3 & 3 \\
\hline $2-3$ & 2 & 5 & 3 & 2 & 3 \\
\hline 3-4 & 2 & 4 & 4 & 5 & 4 \\
\hline $\begin{array}{c}4-5 \\
\text { (first day of sampling event) }\end{array}$ & 6 & 2 & 0 & 2 & 2 \\
\hline $\begin{array}{l}\quad 5 \\
\text { (second day of sampling } \\
\text { event)- } 6\end{array}$ & -- & 5 & 10 & -2 & 4 \\
\hline $6-7$ & -- & -6 & -9 & 16 & 0 \\
\hline $7-8$ & -- & 7 & 9 & 12 & 9 \\
\hline $8-9$ & -- & 10 & 4 & -10 & 1 \\
\hline $9-10$ & -- & -3 & -5 & 11 & 1 \\
\hline $10-11$ & -- & 7 & 0 & -1 & 2 \\
\hline $1-11$ & -- & 33 & 20 & 38 & 30 \\
\hline
\end{tabular}

${ }^{1}$ Numbers are obtained by using original discharge measurement notes and rounding after final computation. Some numbers may be slightly different than previously rounded values in table 2 . Positive values indicate gains, and negative values indicate losses.

Table 4. Gains and losses per river mile along Salt Creek near Lincoln, Nebraska, June 20, 1994, August 16-17, 1994, September 28-29, 1994, and August 28-30, 1995

$[-$, no data $]$

\begin{tabular}{cccccc}
\hline \multirow{2}{*}{$\begin{array}{c}\text { Salt Creek } \\
\text { stream reach }\end{array}$} & \multicolumn{5}{c}{ Gains and losses per river mile, in cubic feet per second per mile } \\
\cline { 2 - 6 } & June 20, 1994 & $\begin{array}{c}\text { August 16-17, } \\
\mathbf{1 9 9 4}\end{array}$ & $\begin{array}{c}\text { September 28- } \\
\mathbf{2 9 ,} \text { 1994 }\end{array}$ & $\begin{array}{c}\text { August 28-30, } \\
\text { 1995 }\end{array}$ & Mean \\
\hline $1-2$ & 2 & 1 & 1 & 2 & 2 \\
$2-3$ & 1 & 3 & 2 & 1 & 2 \\
$3-4$ & 1 & 2 & 2 & 2 & 2 \\
$4-5$ & 9 & 4 & 1 & 4 & 5 \\
$5-6$ & -- & 6 & 13 & -3 & 5 \\
$6-7$ & -- & -5 & -7 & 13 & 0 \\
$7-8$ & -- & 4 & 5 & 7 & 5 \\
$8-9$ & -- & 4 & 2 & -4 & 1 \\
$9-10$ & -- & -6 & -10 & 21 & 2 \\
$10-11$ & -- & 6 & 0 & -1 & 2 \\
$1-11$ & -- & 2 & 1 & 3 & 2 \\
\hline
\end{tabular}

'Positive values indicate gains, and negative values indicate losses. 
z

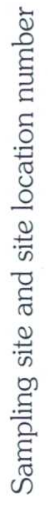

$\infty \stackrel{\text { จ }}{*}$ กे N

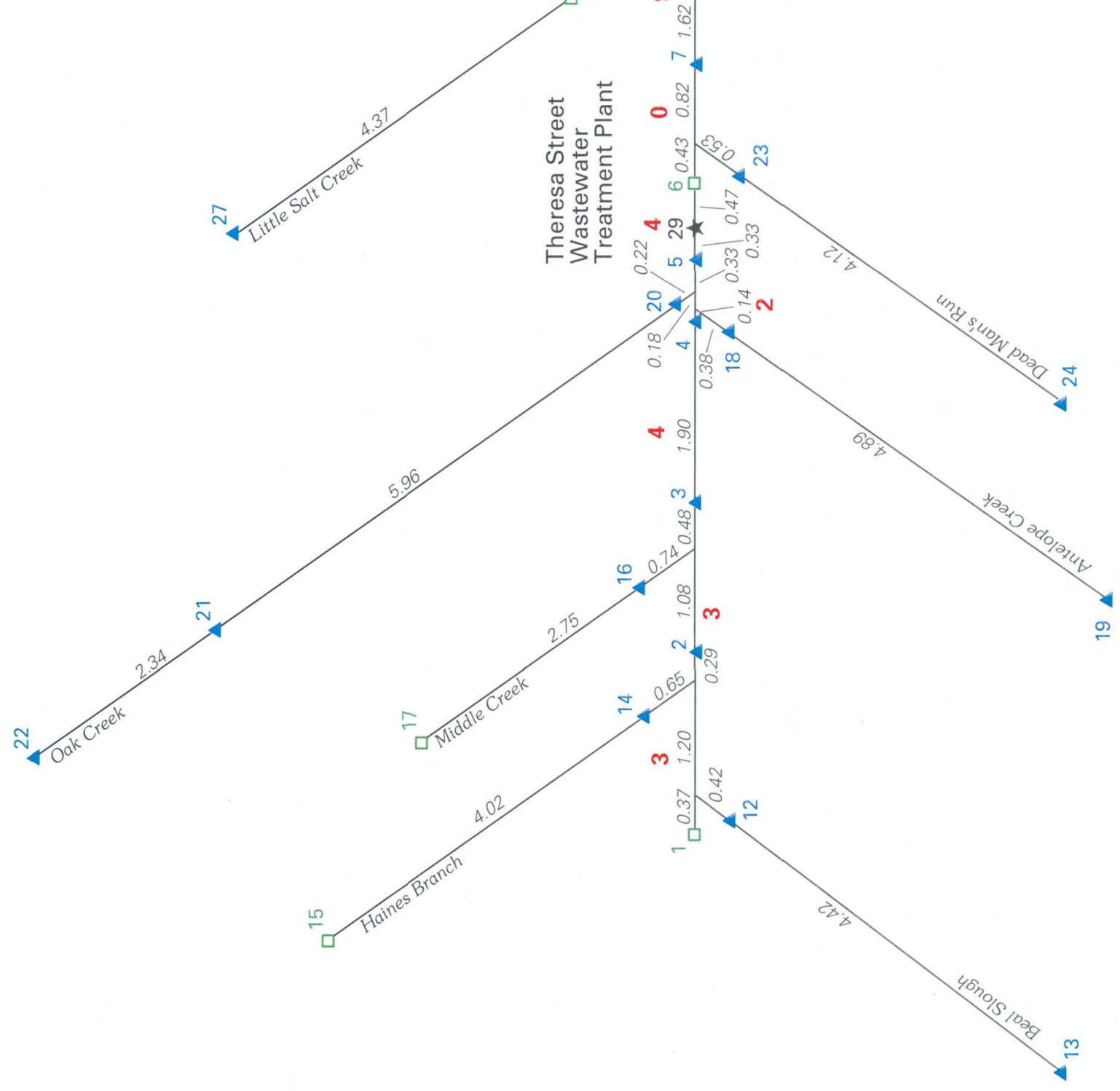

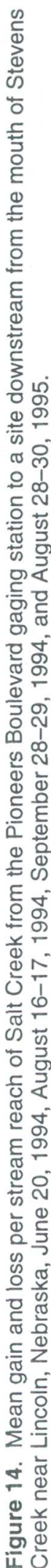




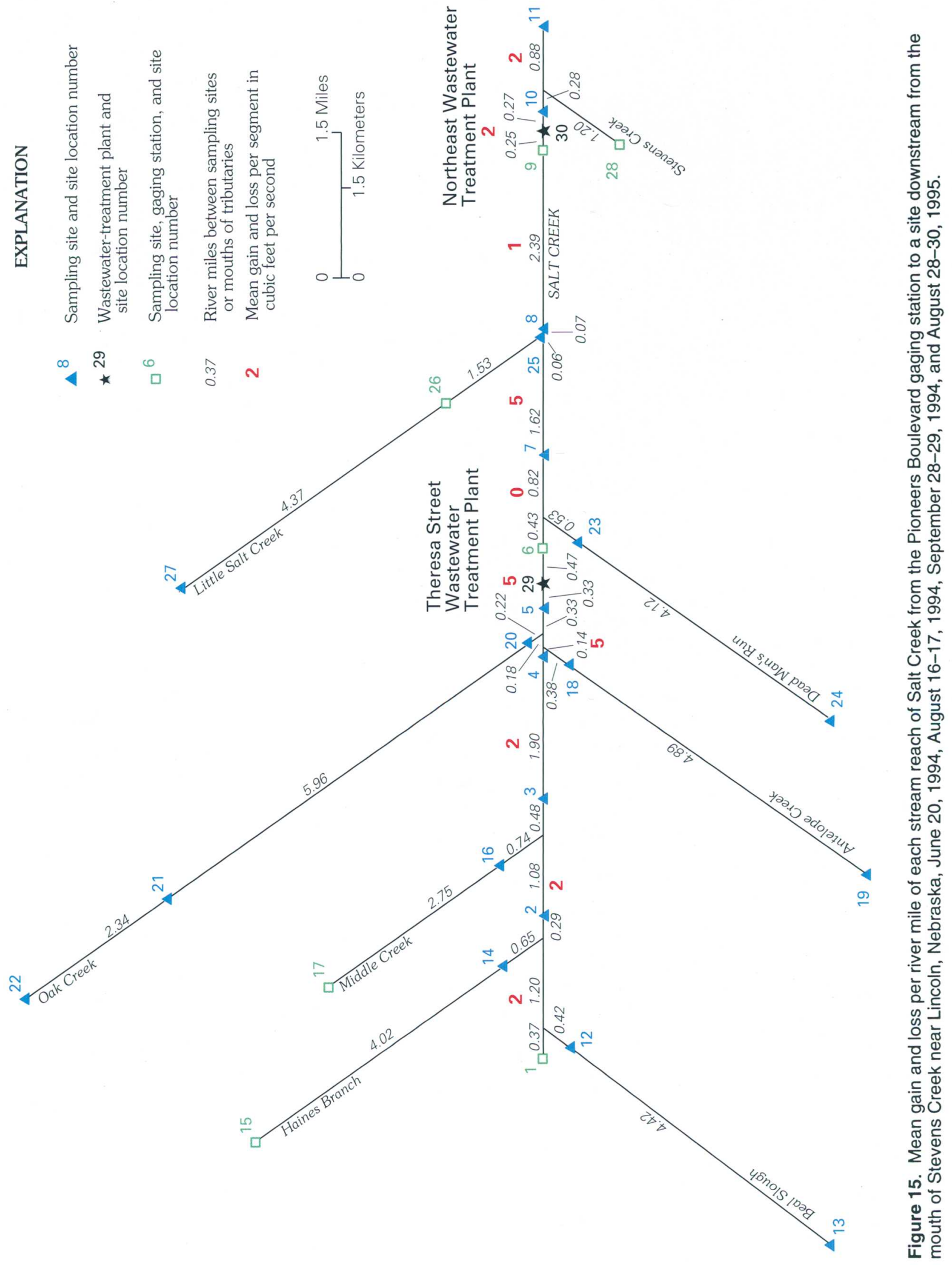




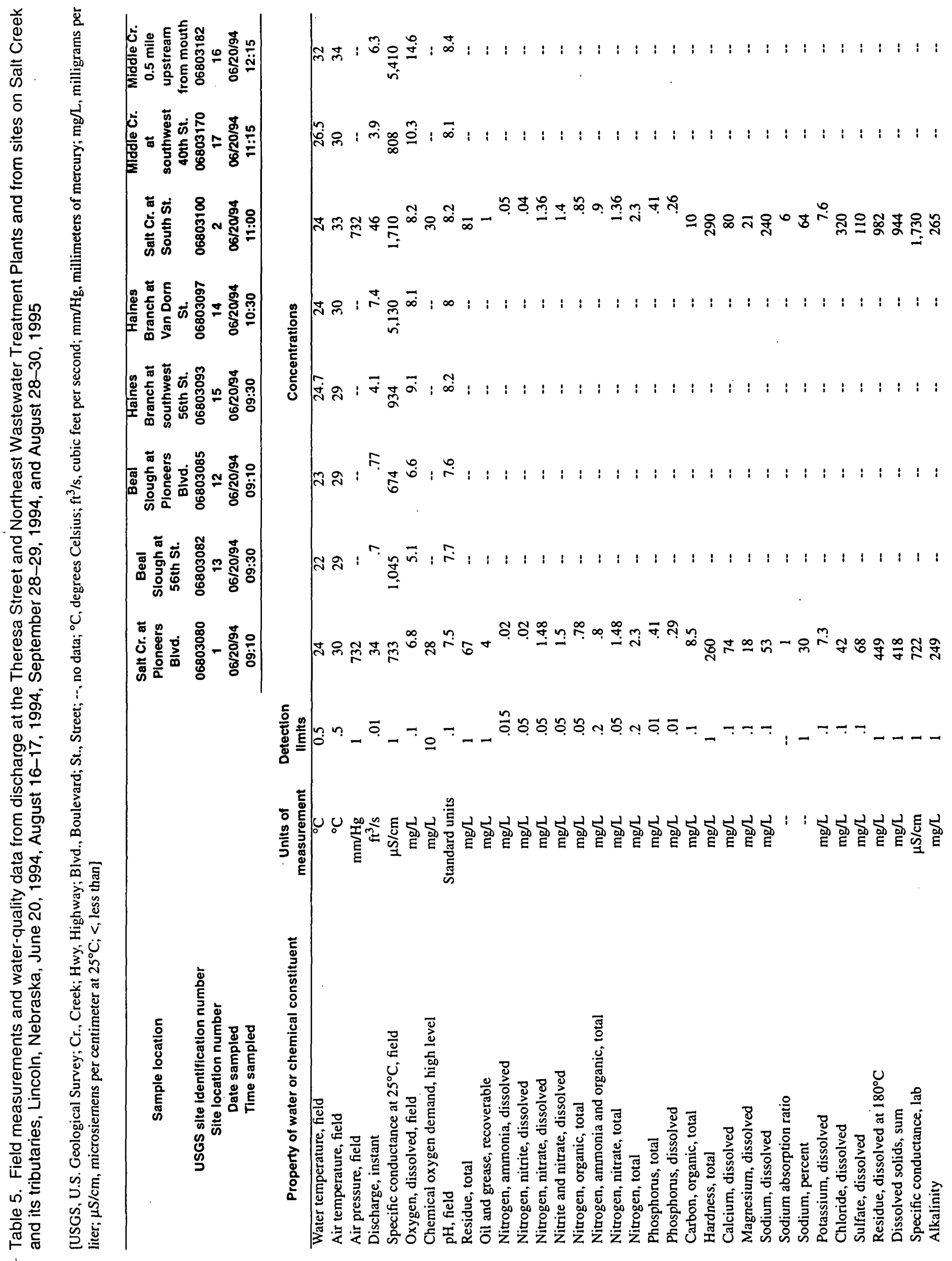




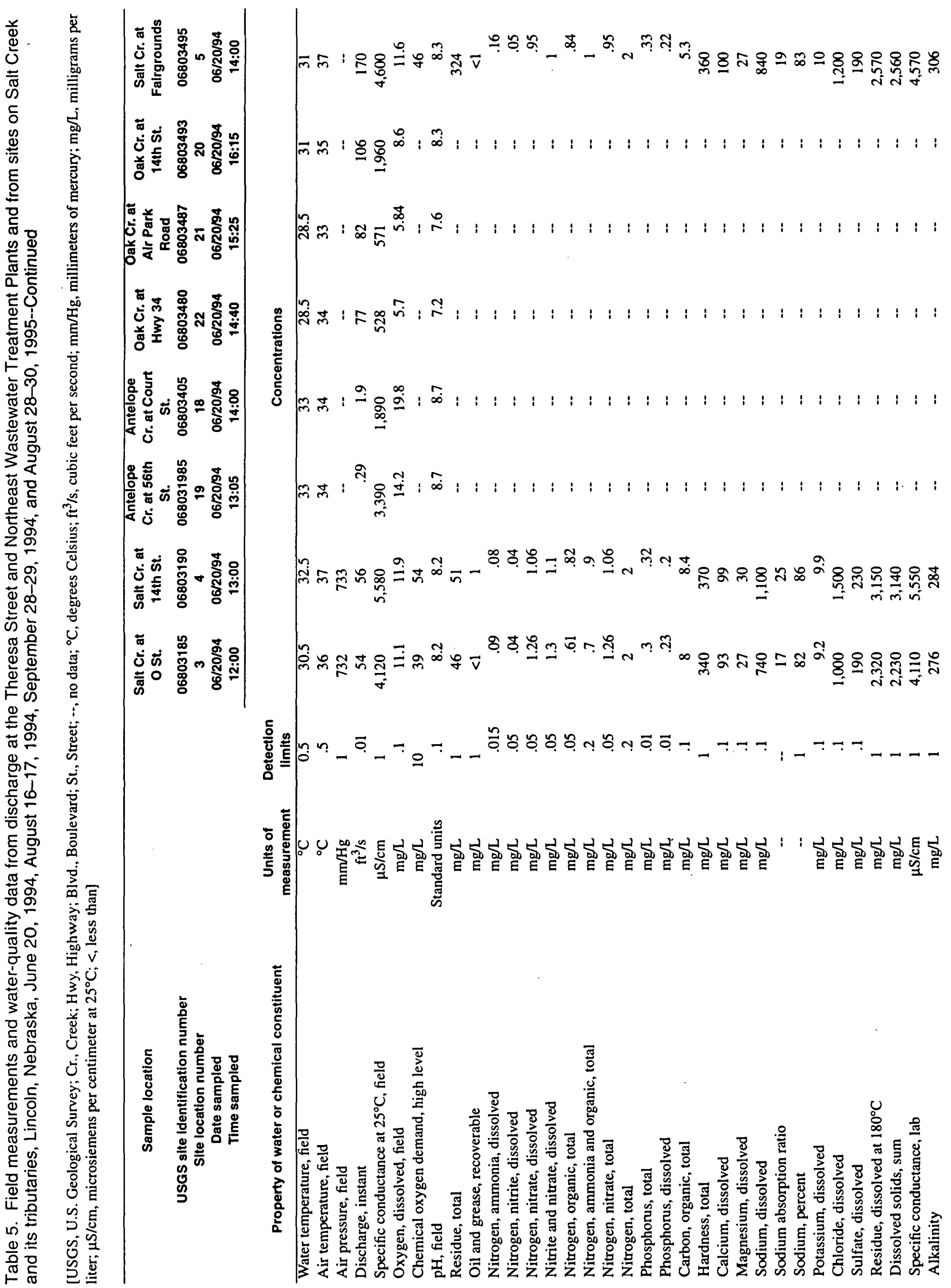




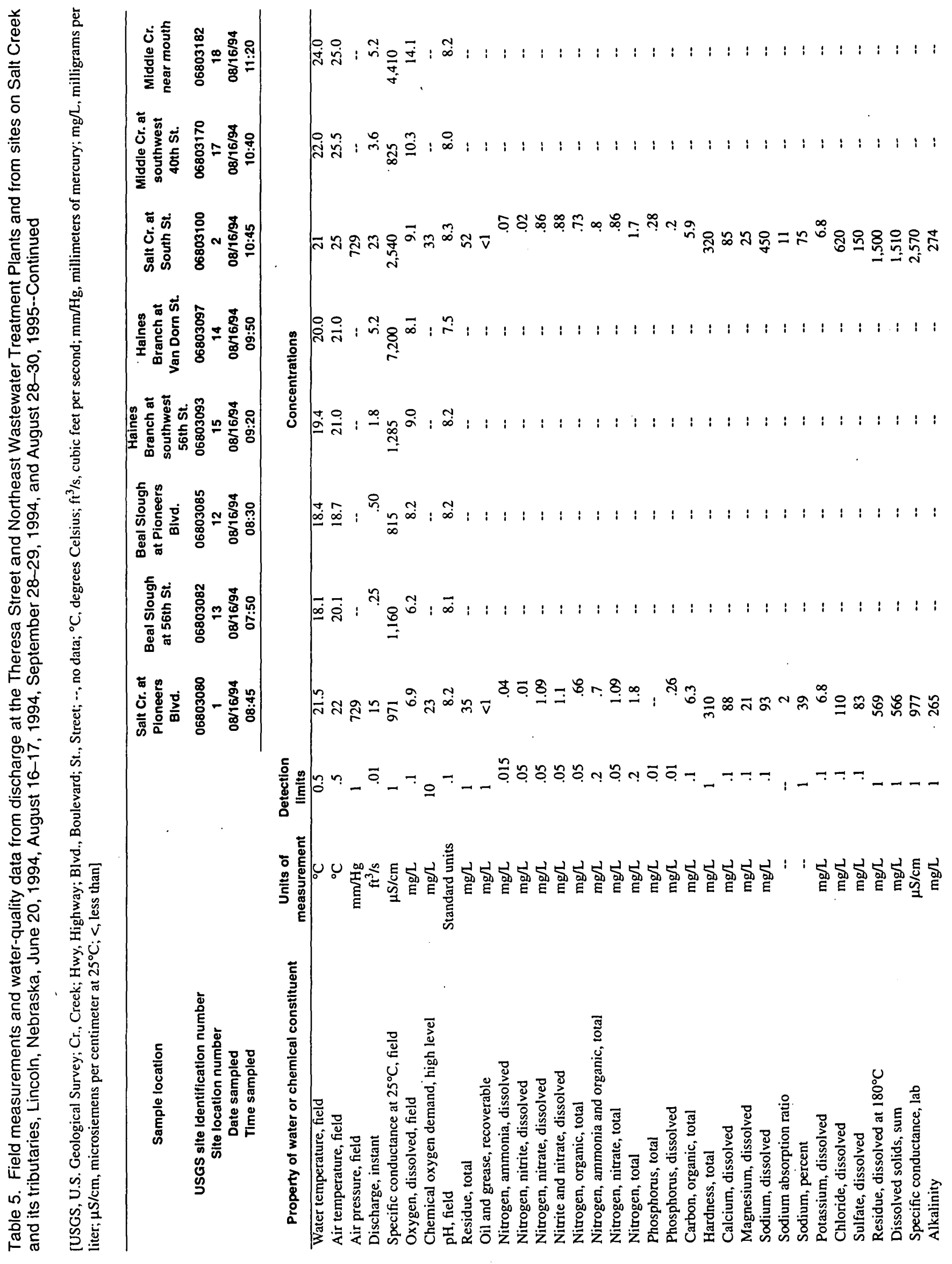




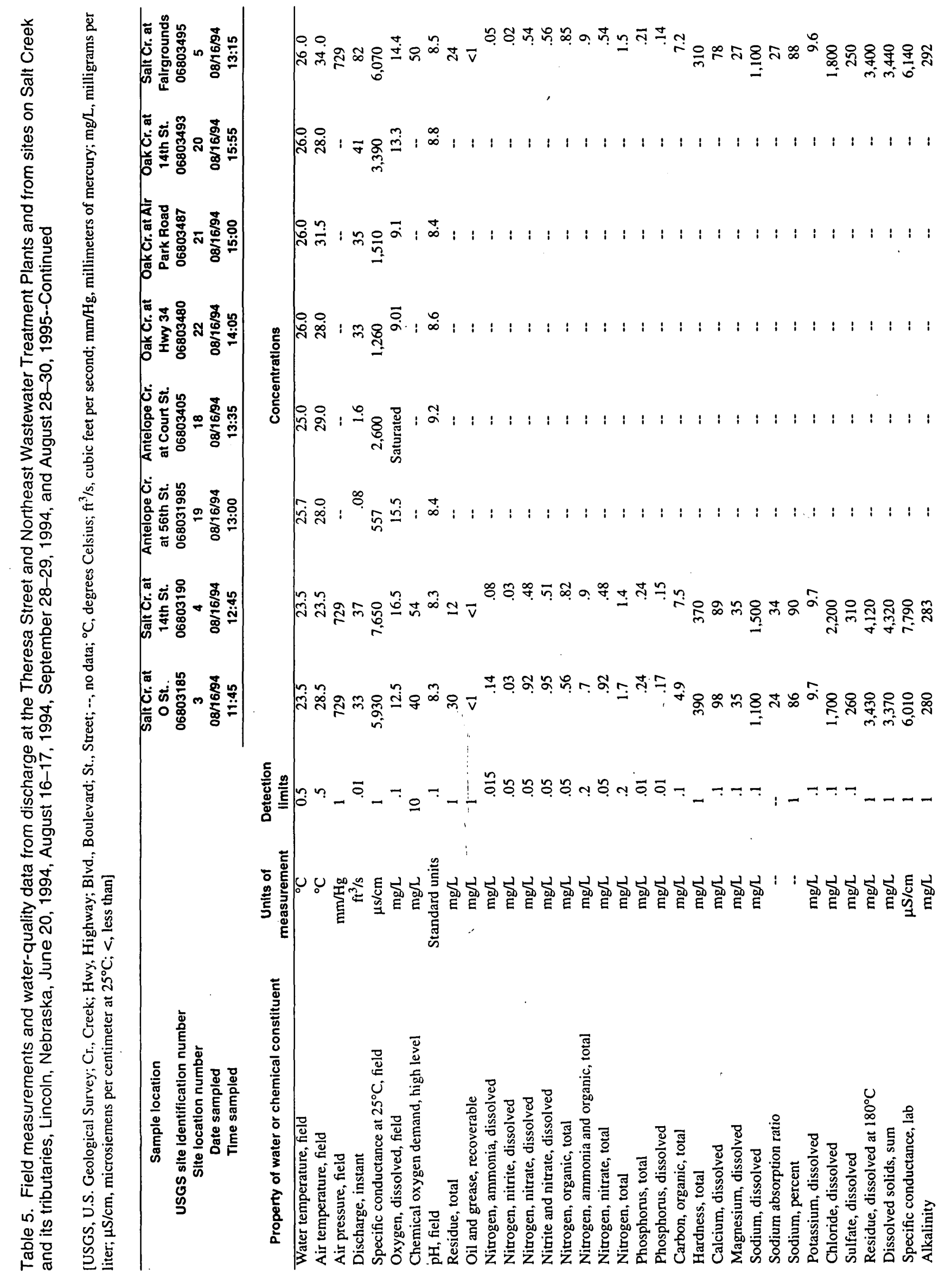




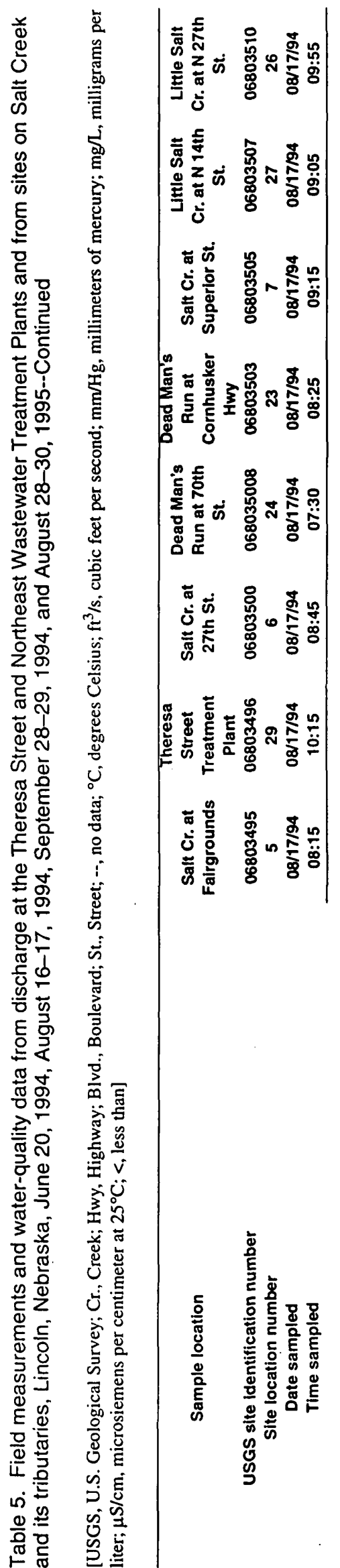

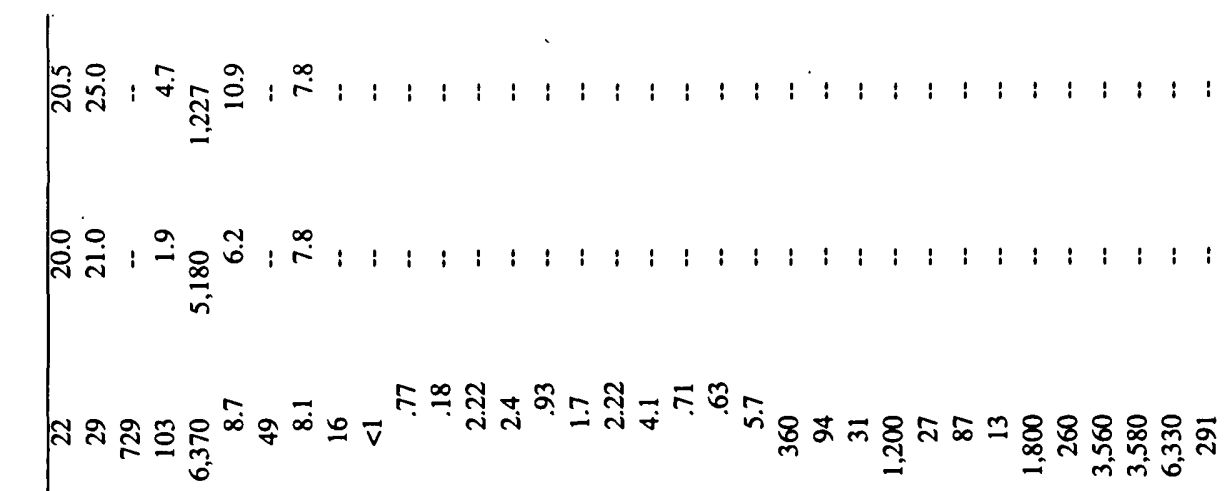

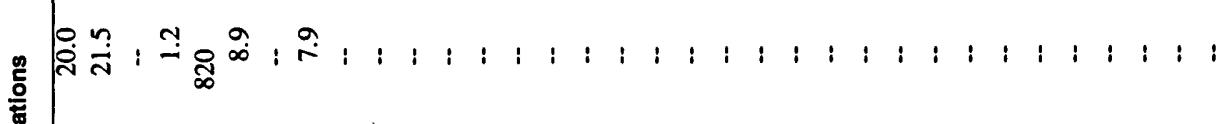

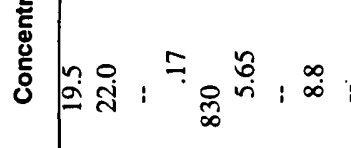

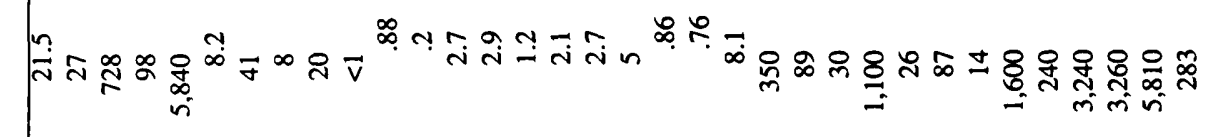

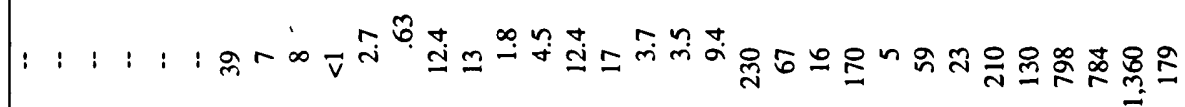

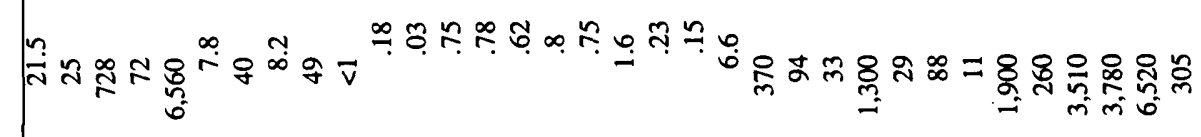

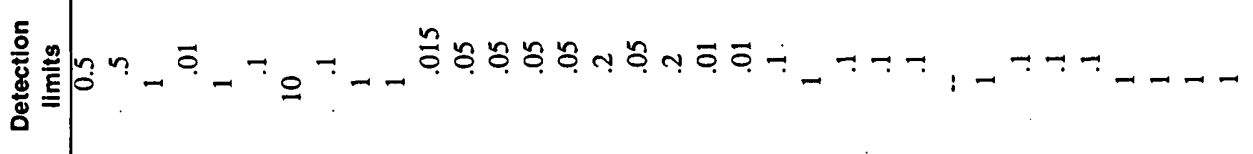

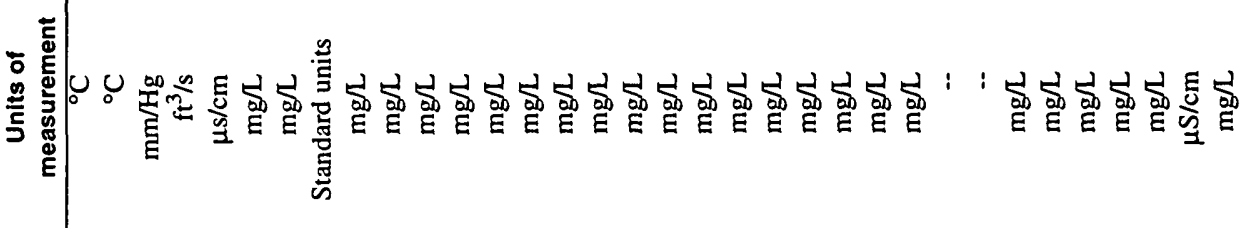

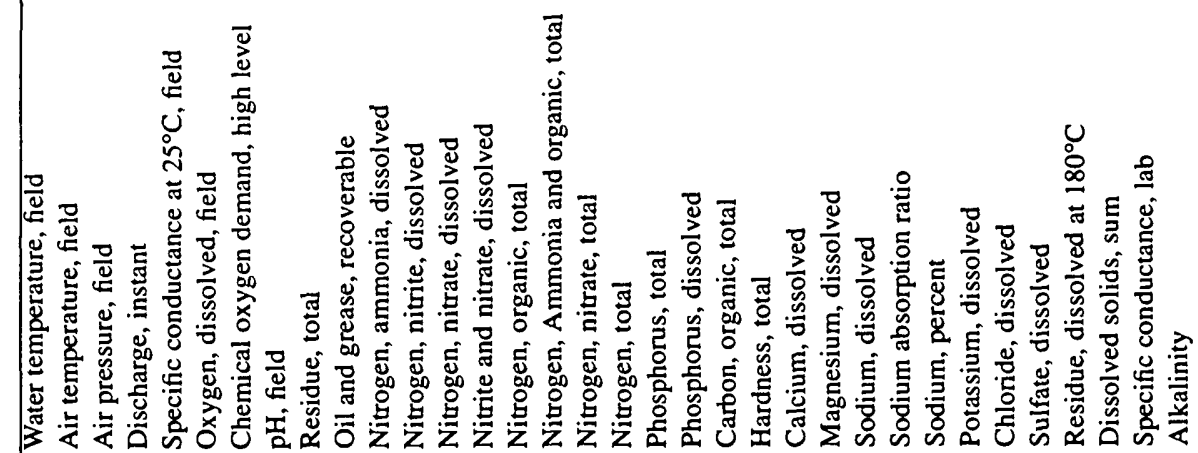




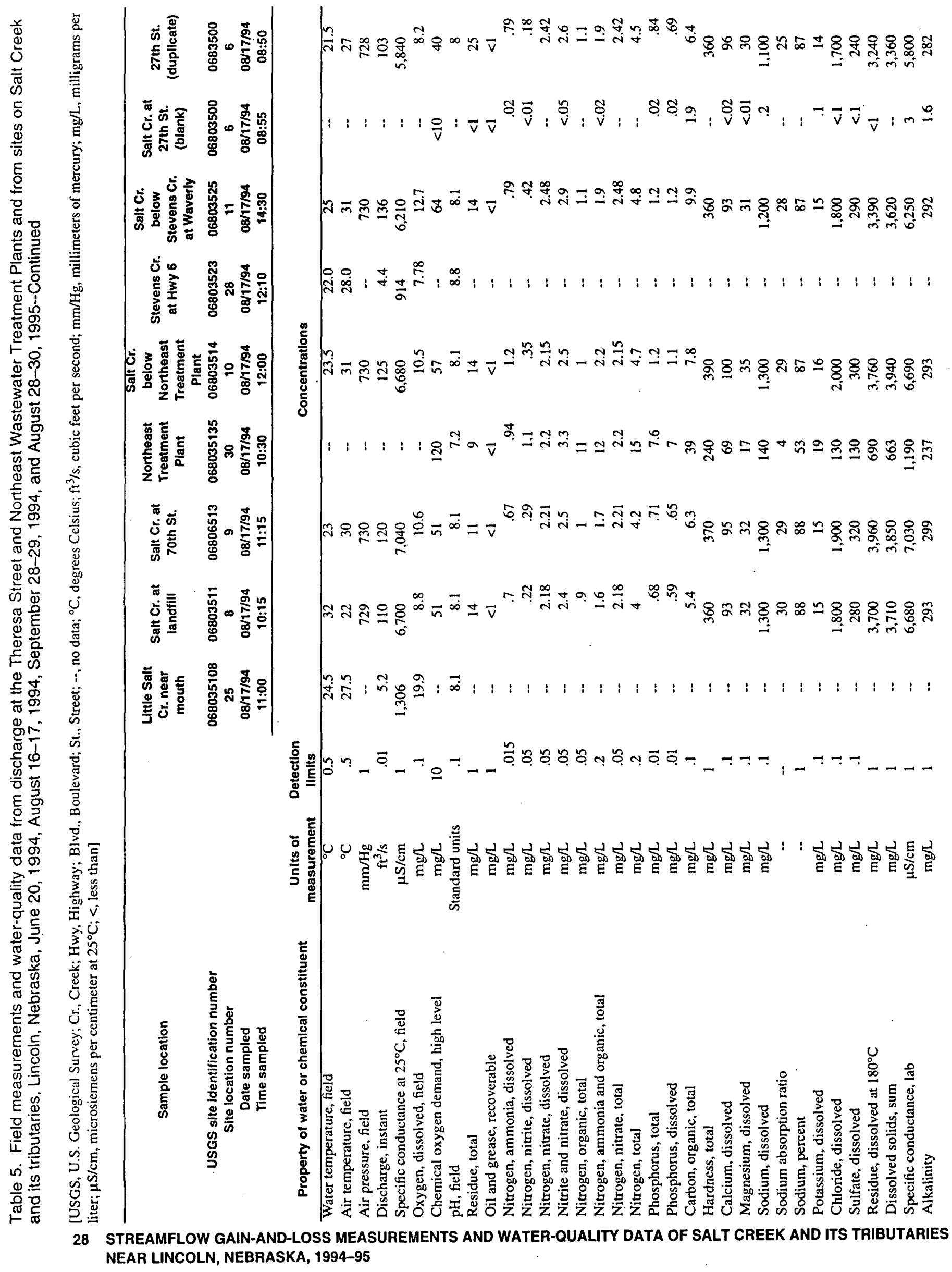




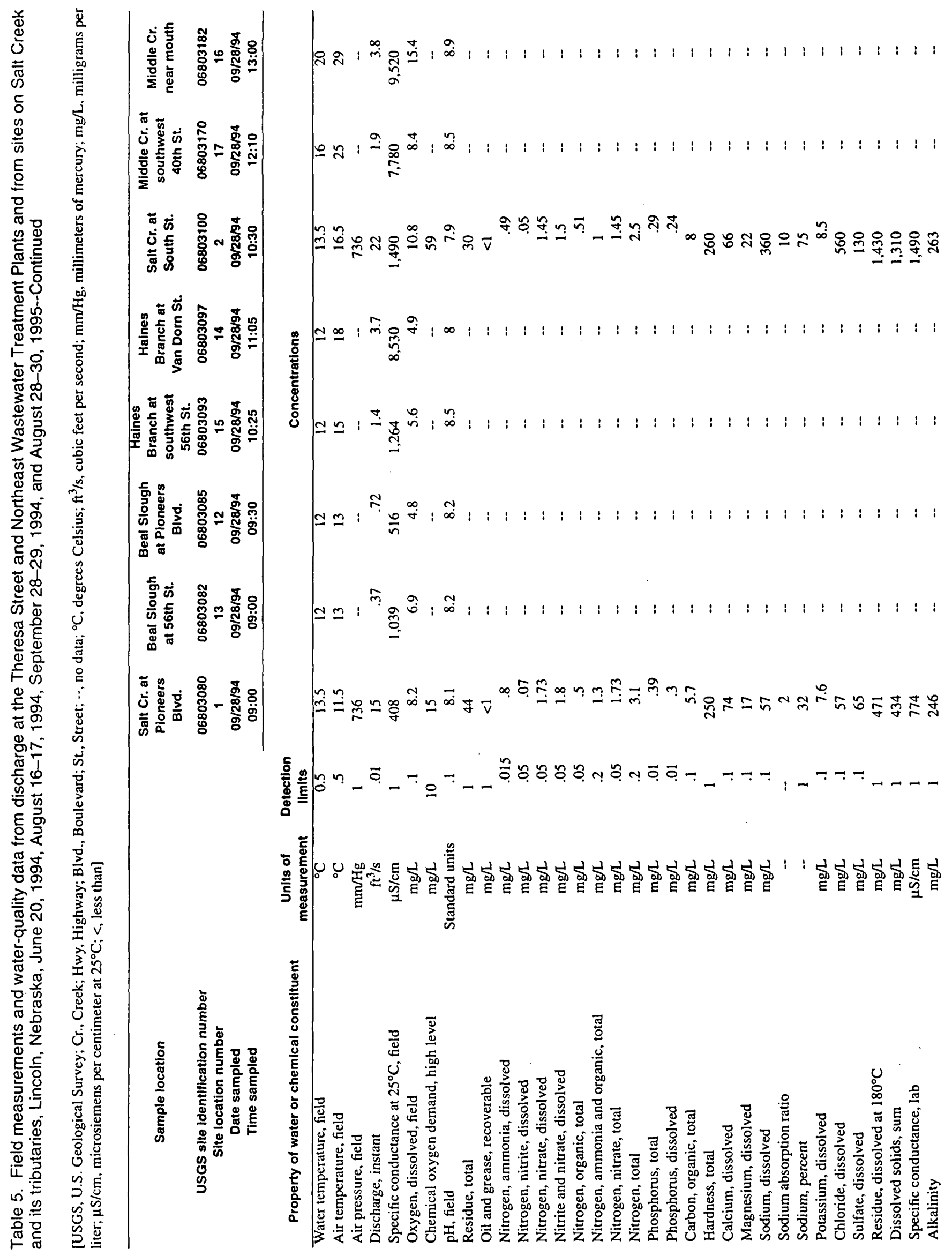




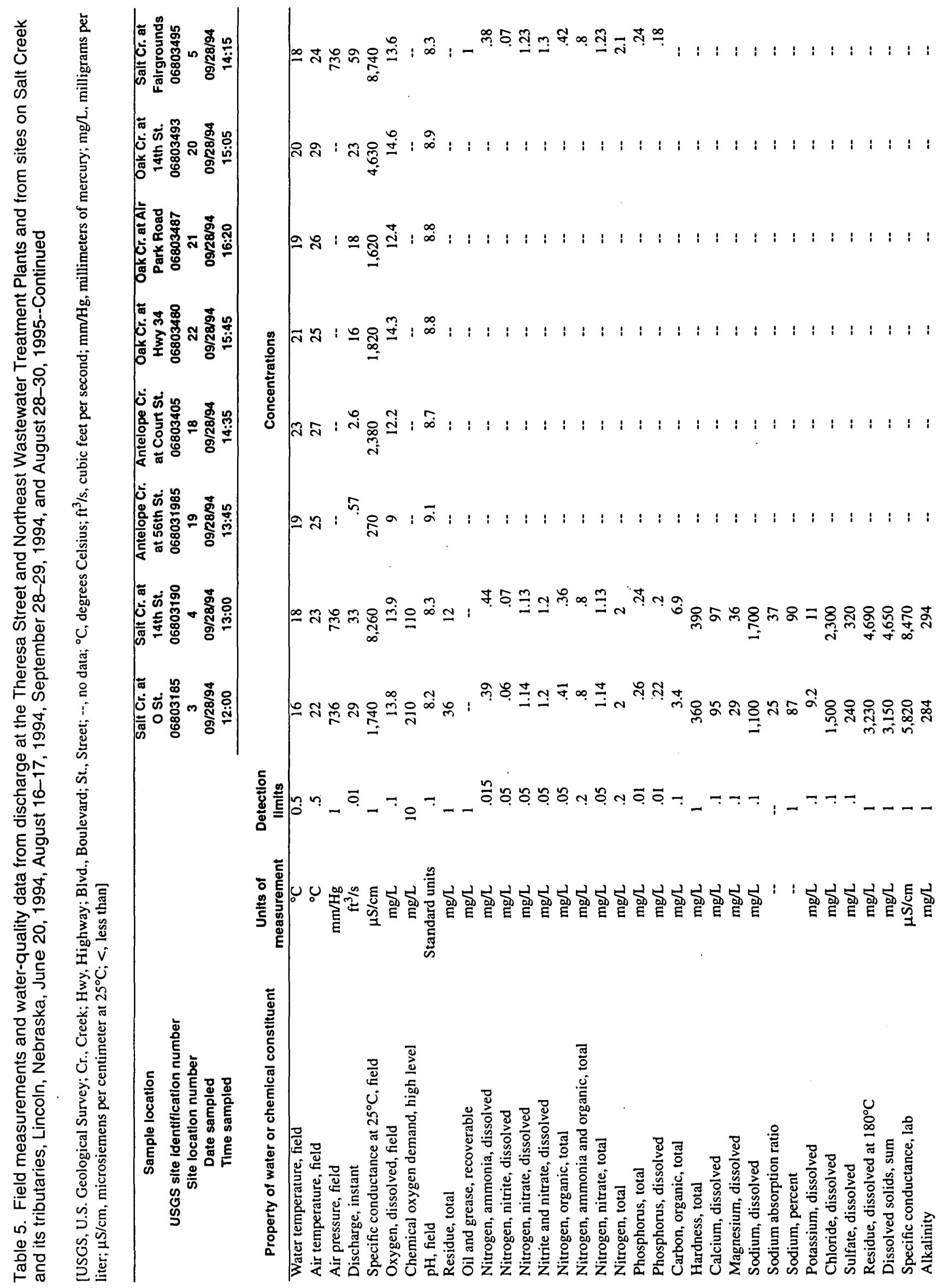



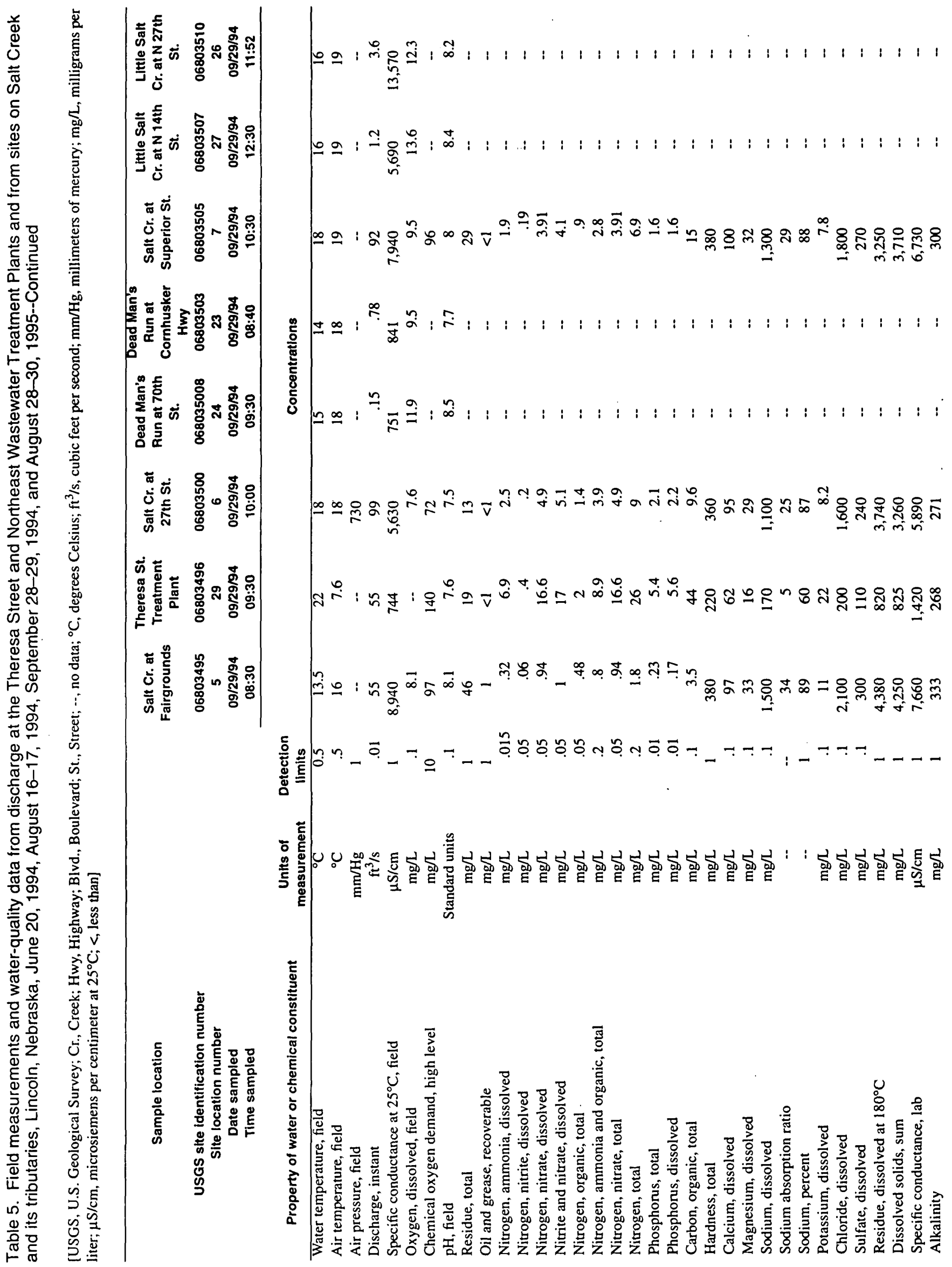


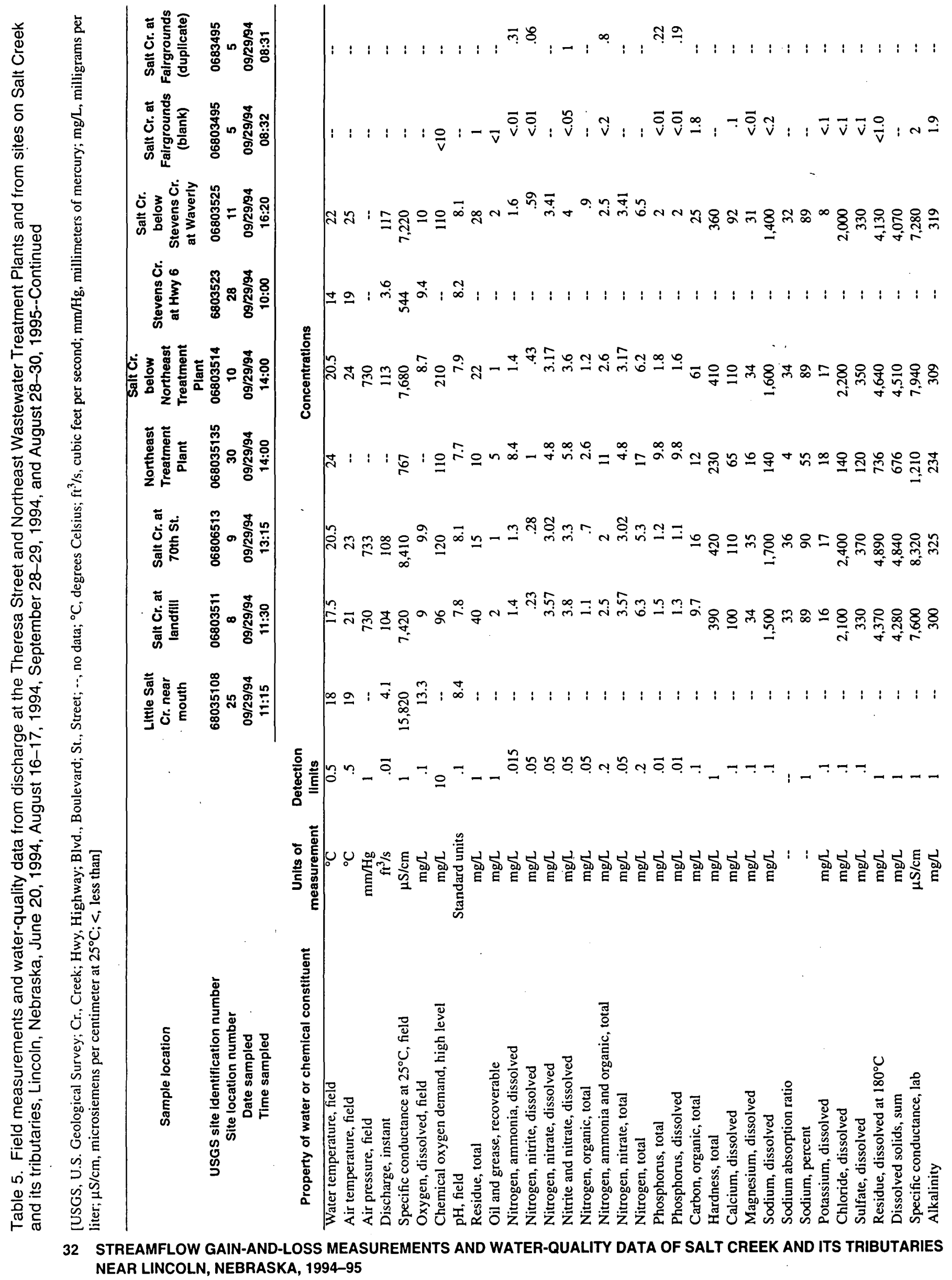




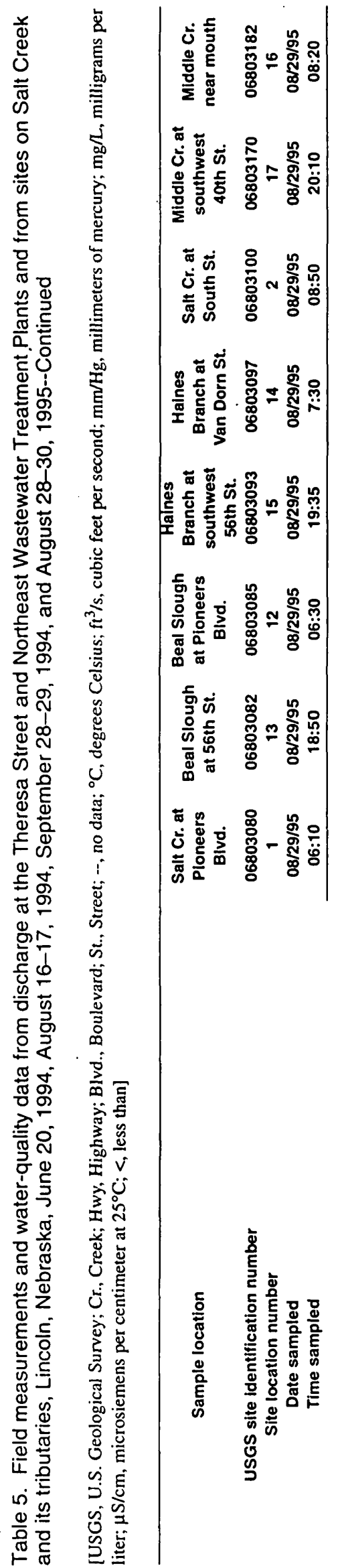

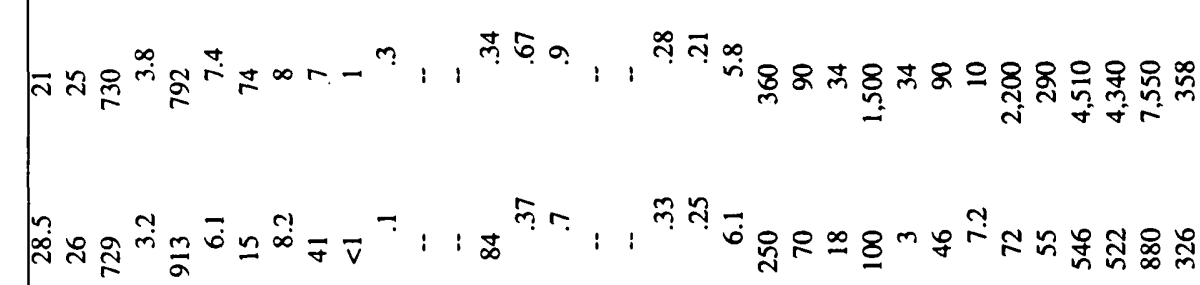

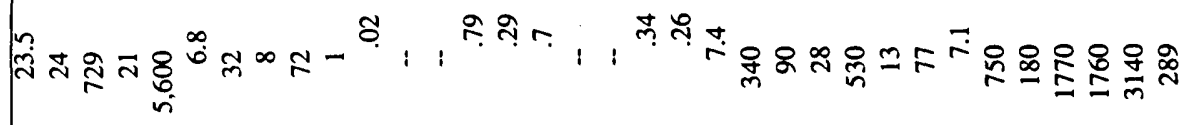

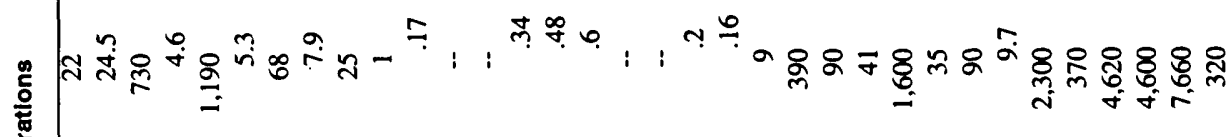

ठำ

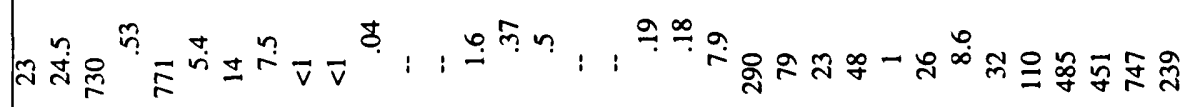

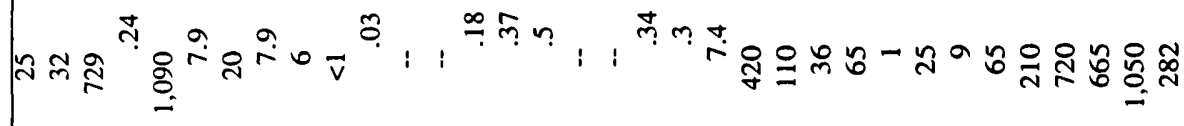

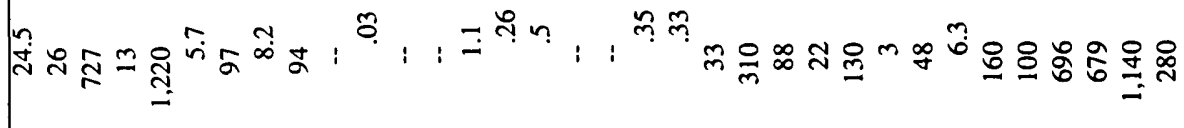

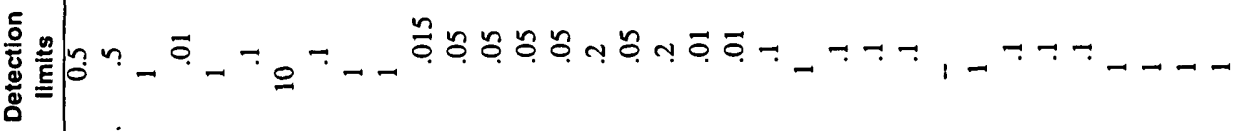

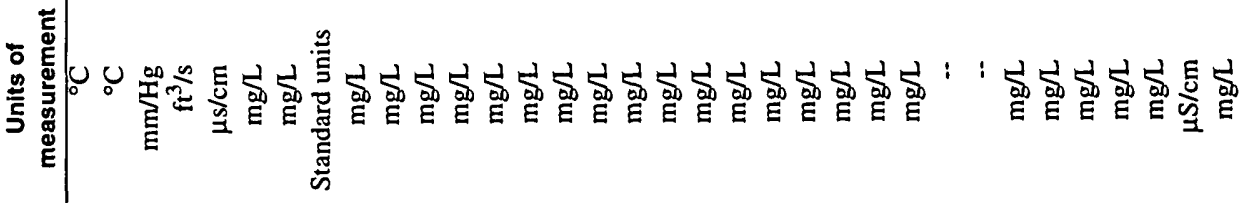

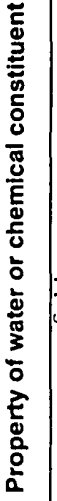

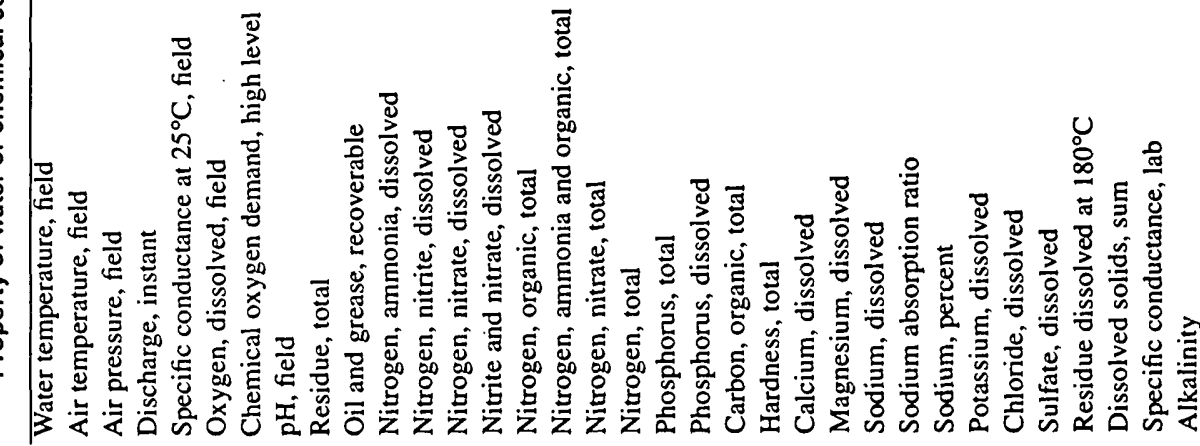




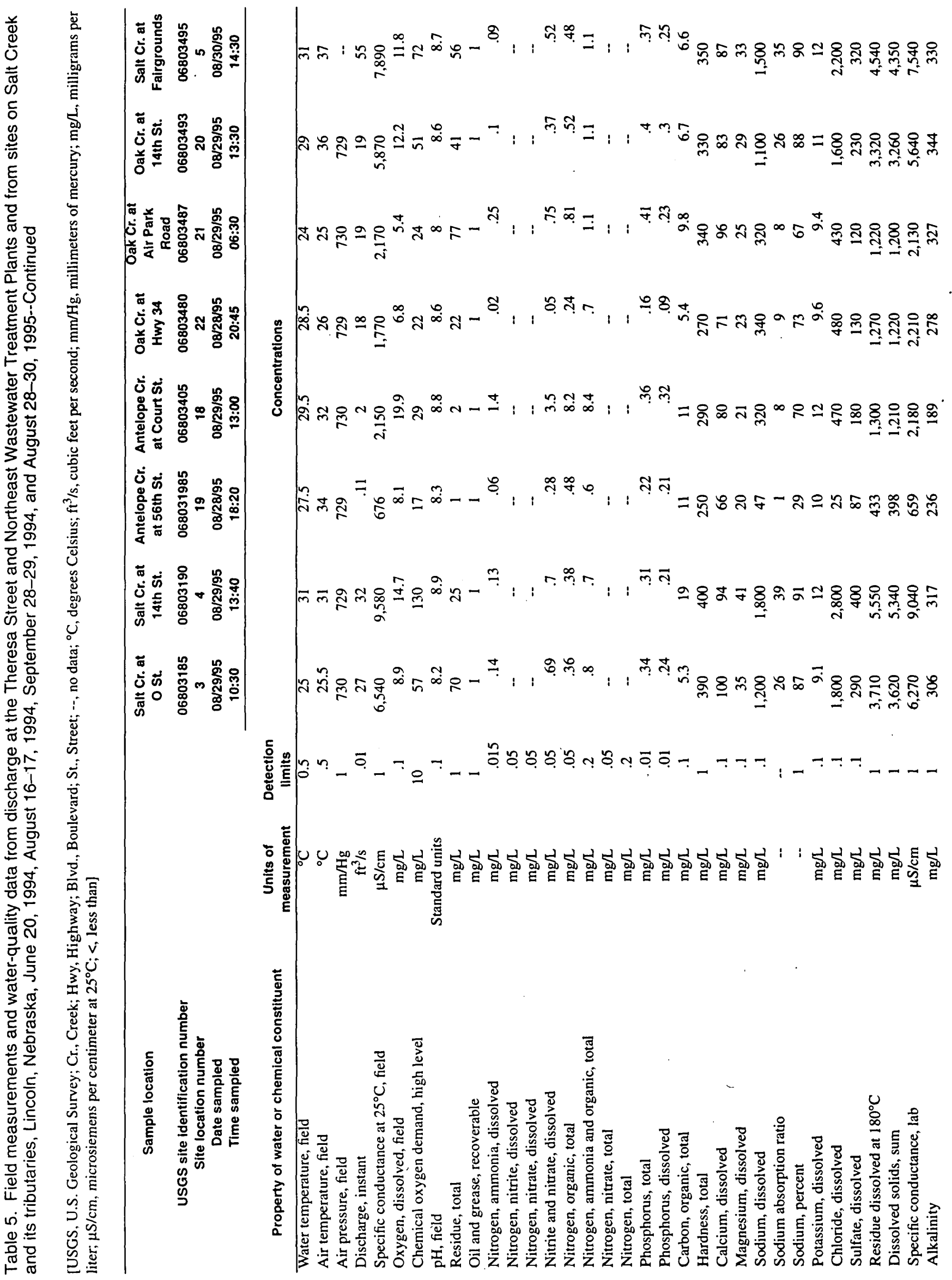

34 STREAMFLOW GAIN-AND-LOSS MEASUREMENTS AND WATER-QUALITY DATA OF SALT CREEK AND ITS TRIBUTARIES NEAR LINCOLN, NEBRASKA, 1994-95 


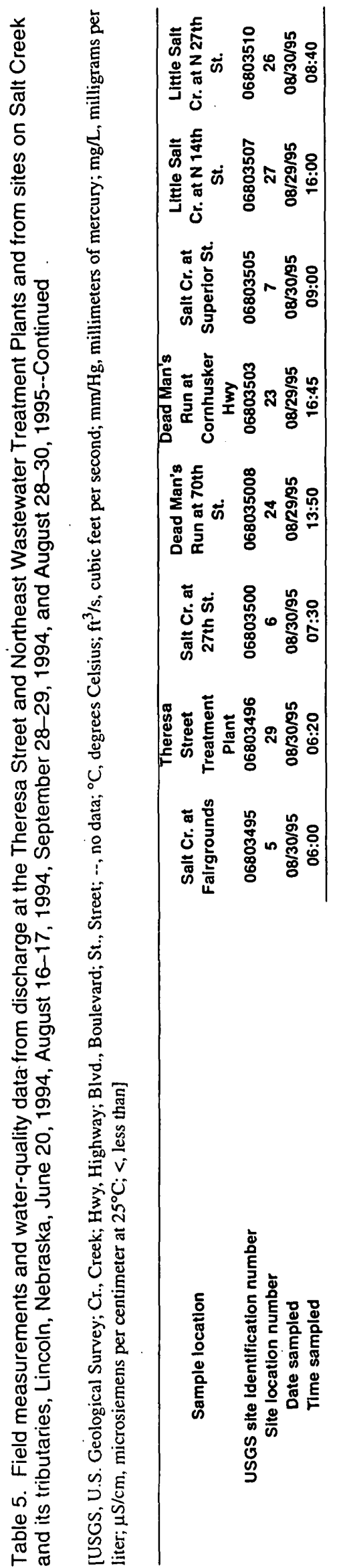

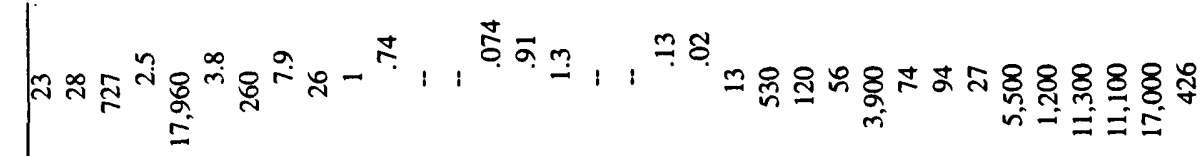

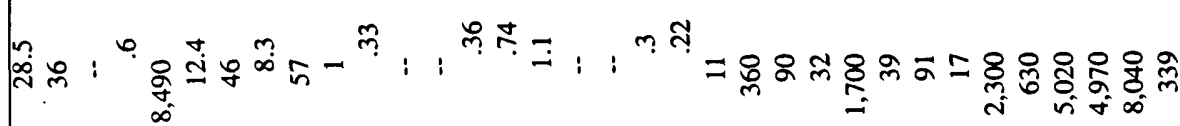

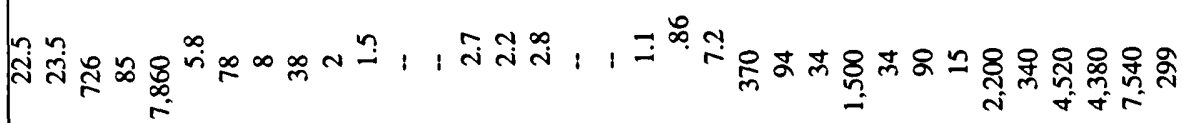

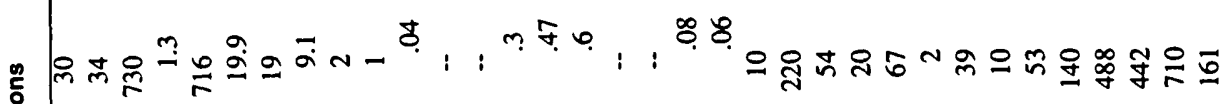

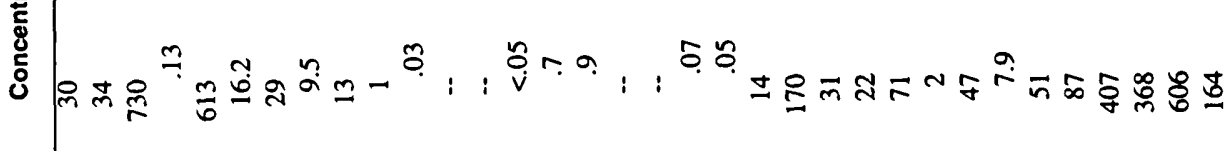

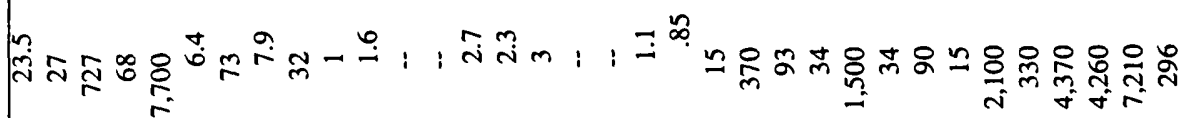

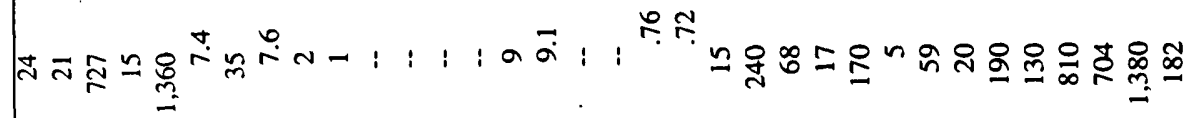

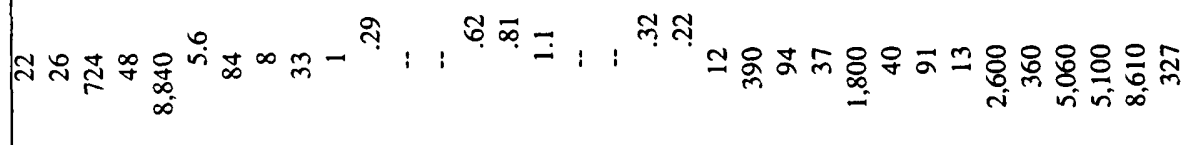

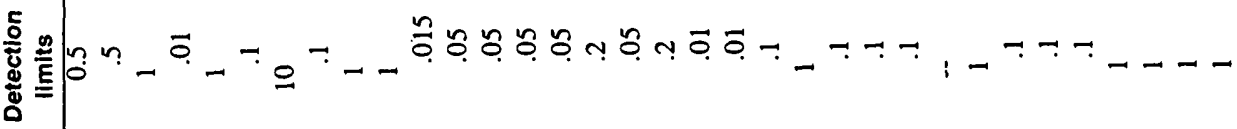

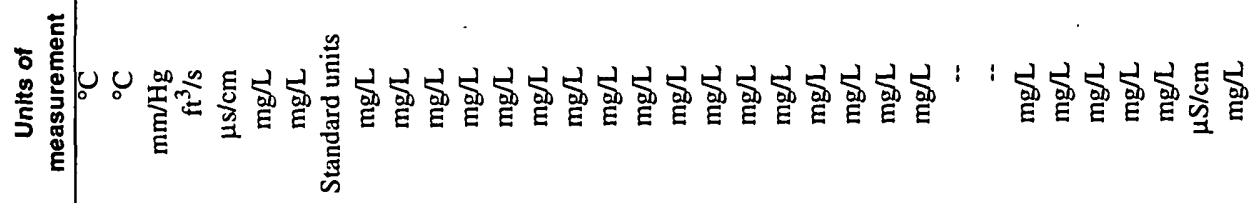

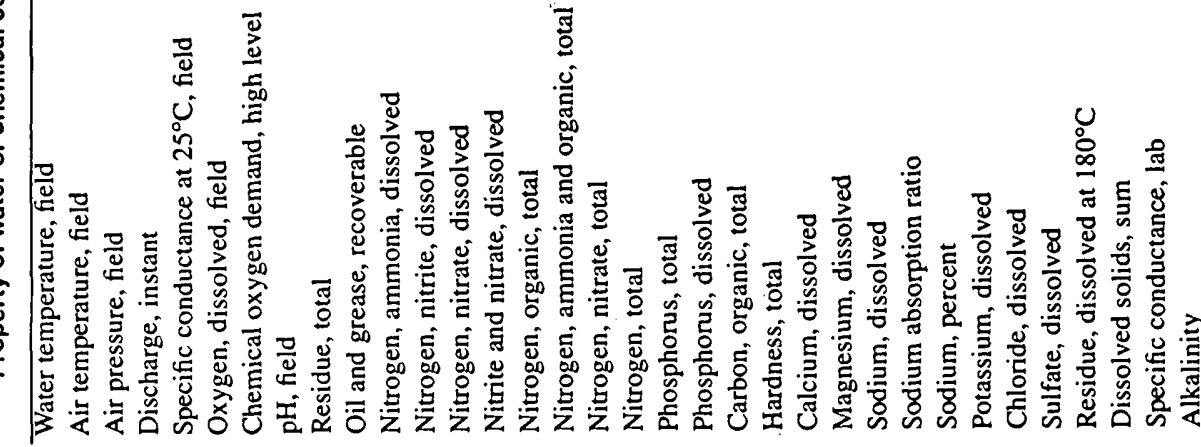




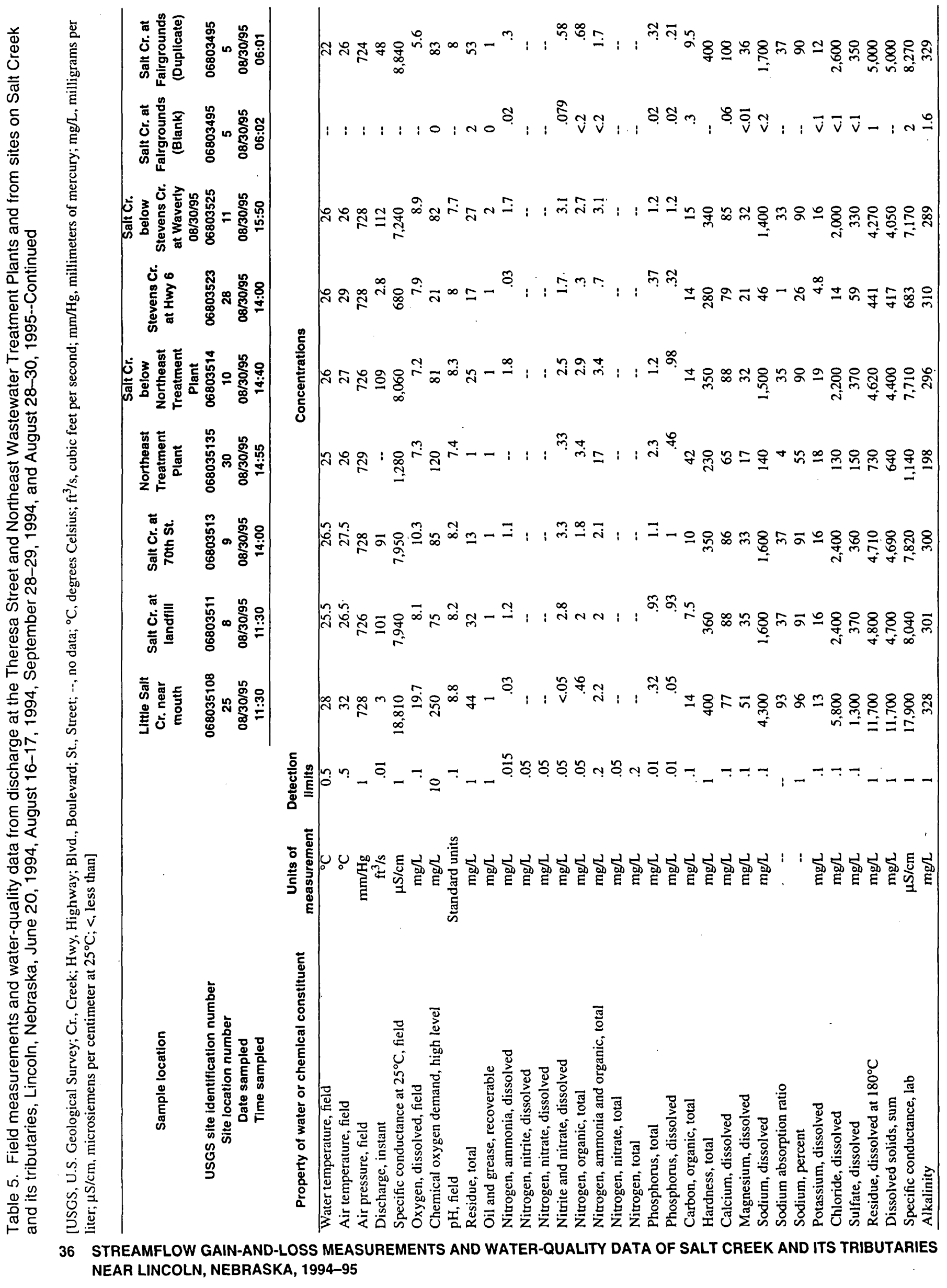




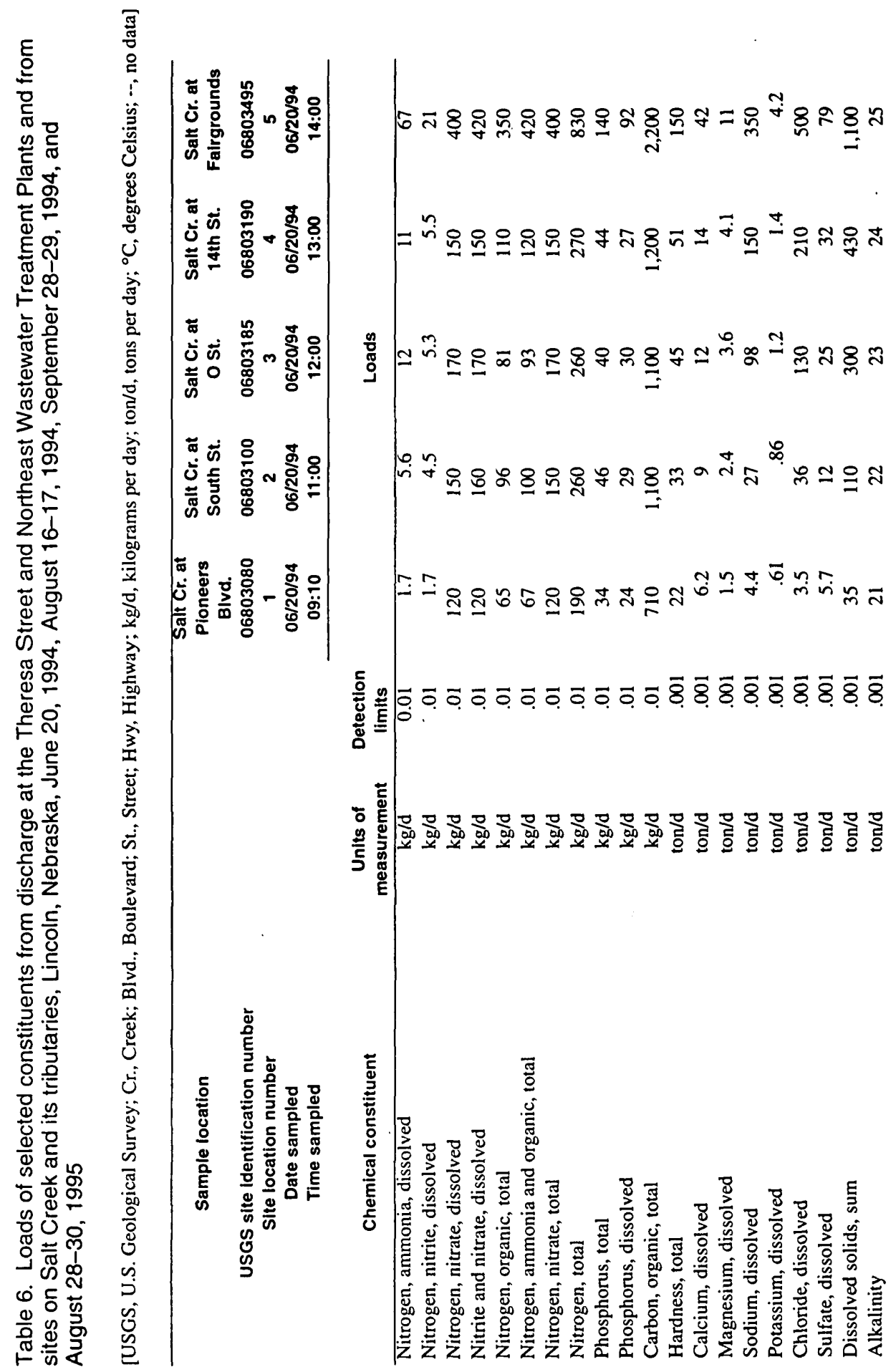




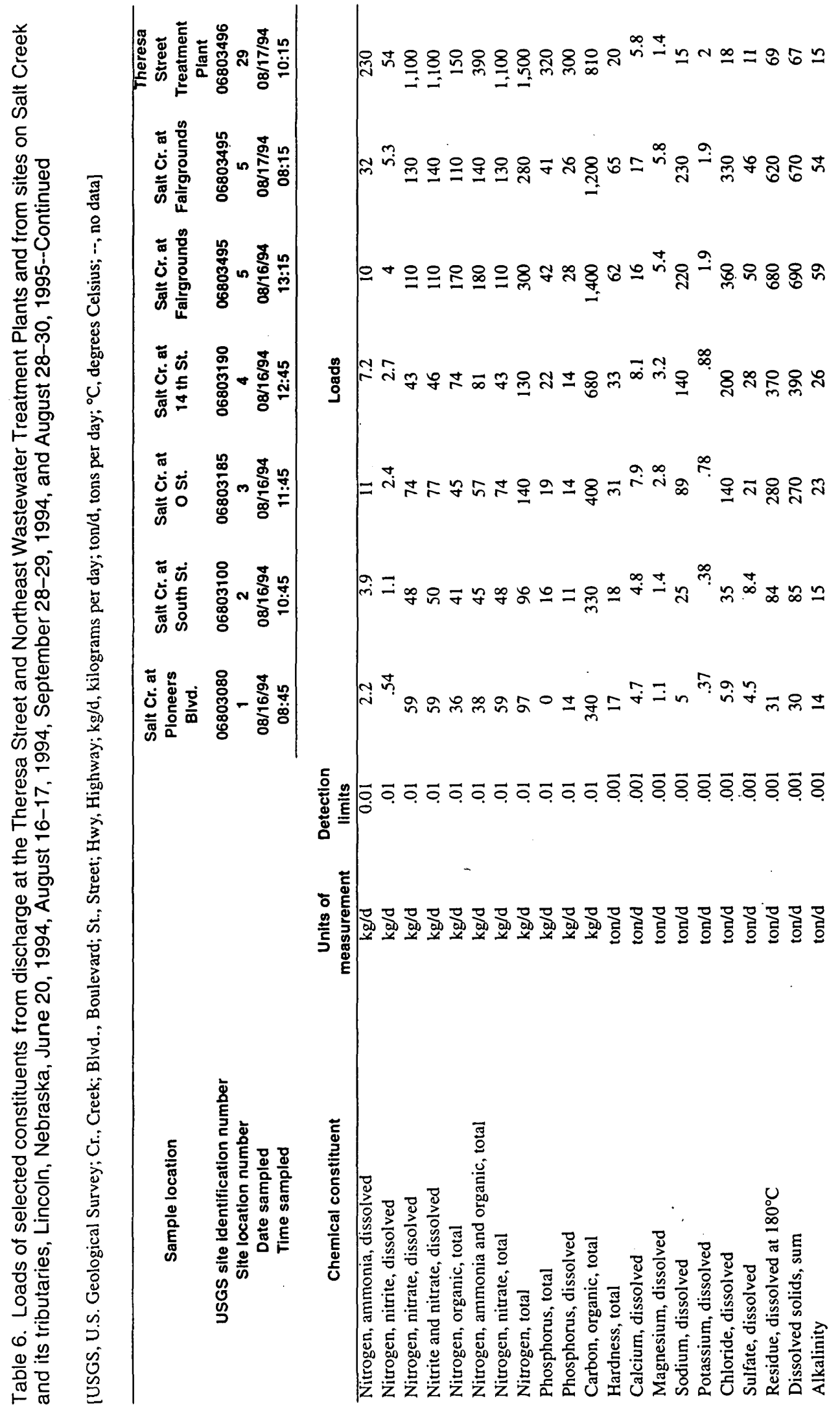




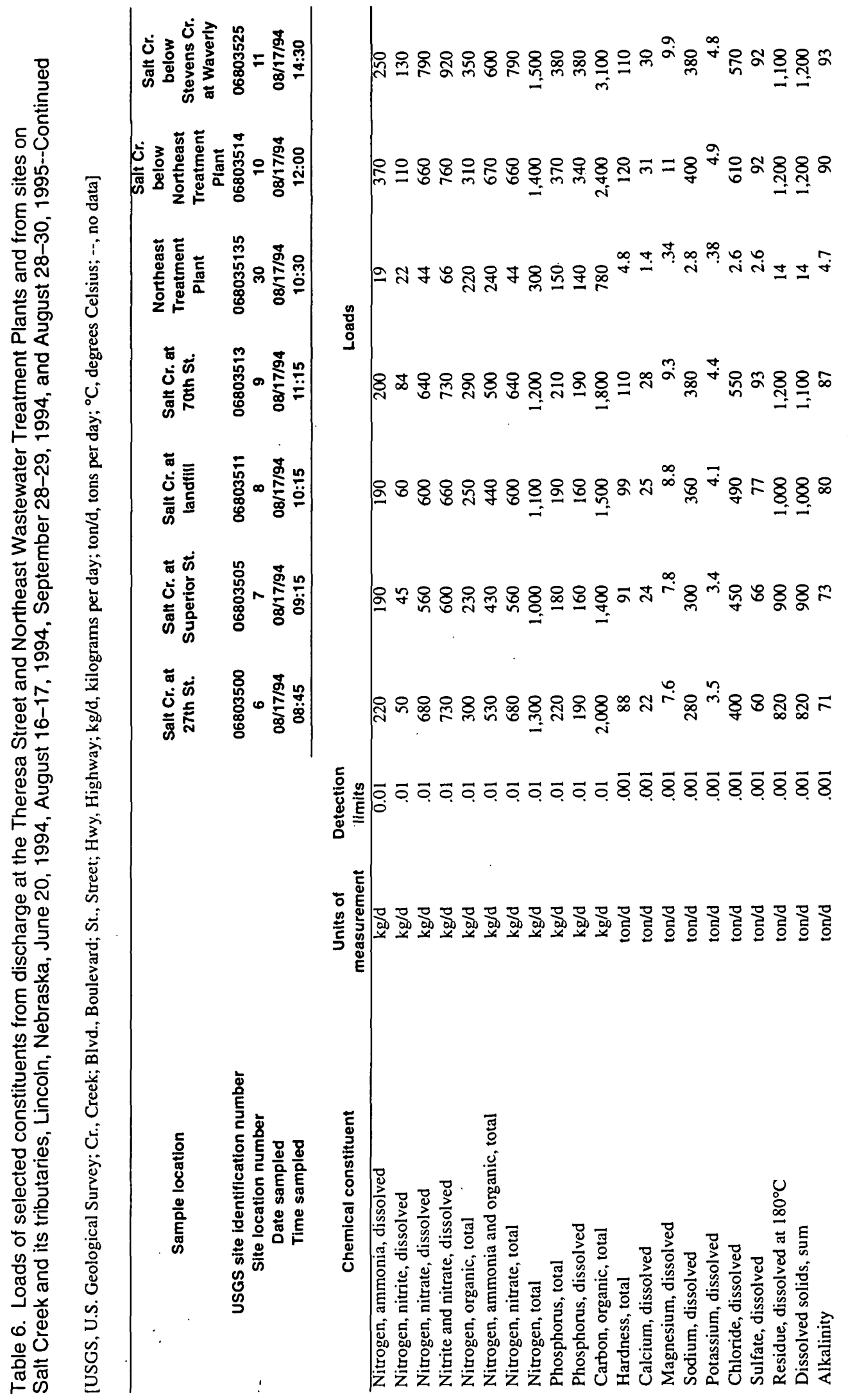




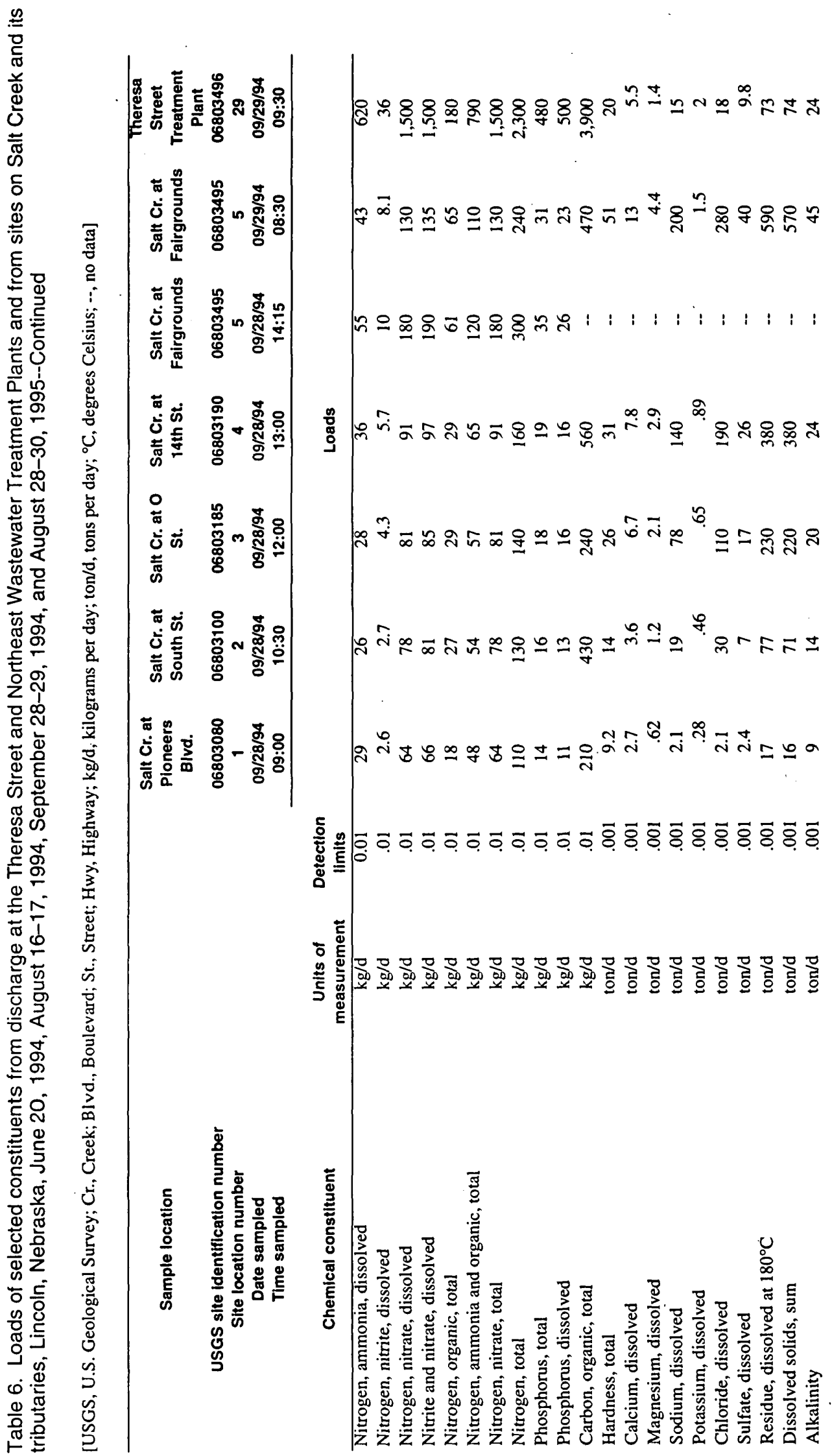




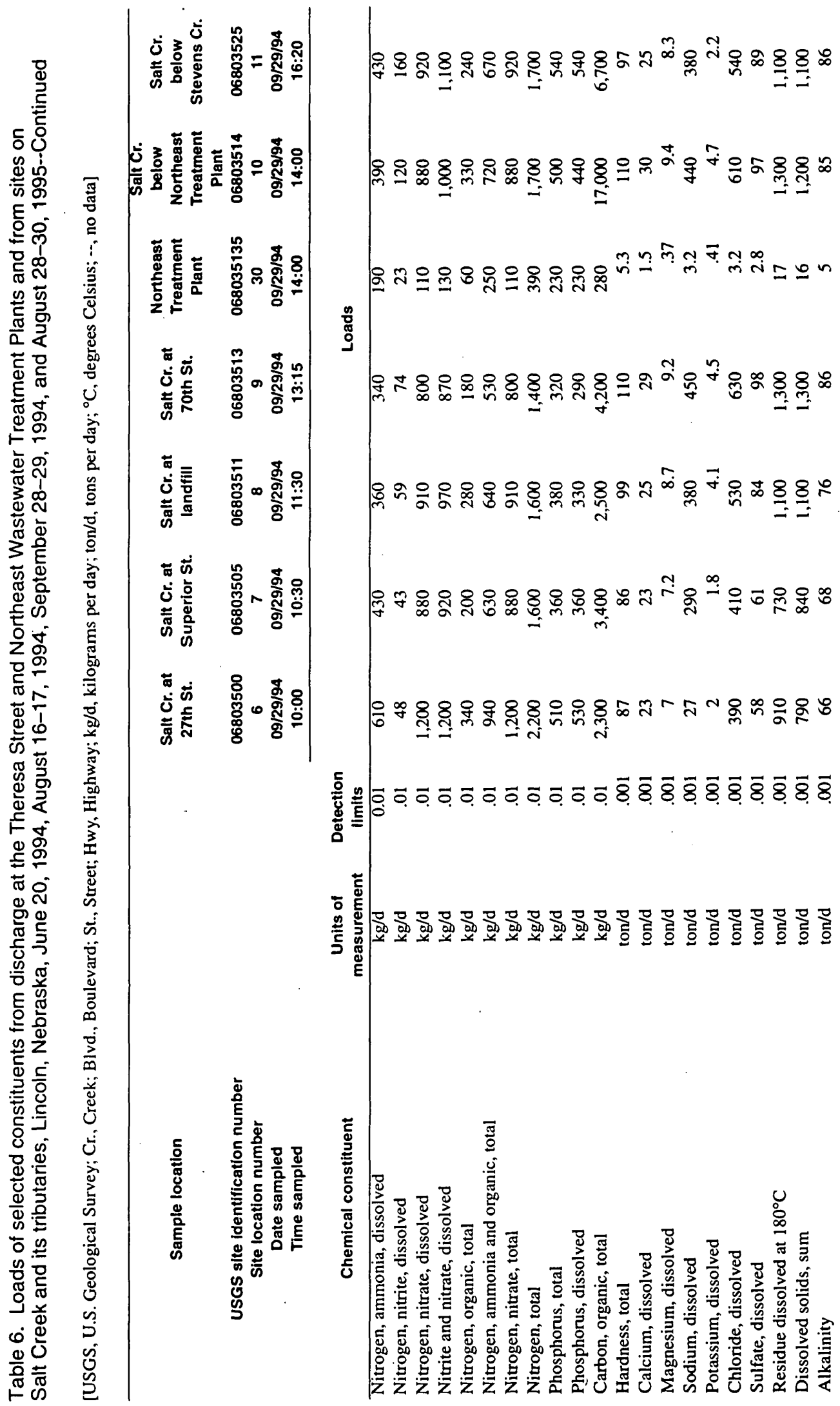




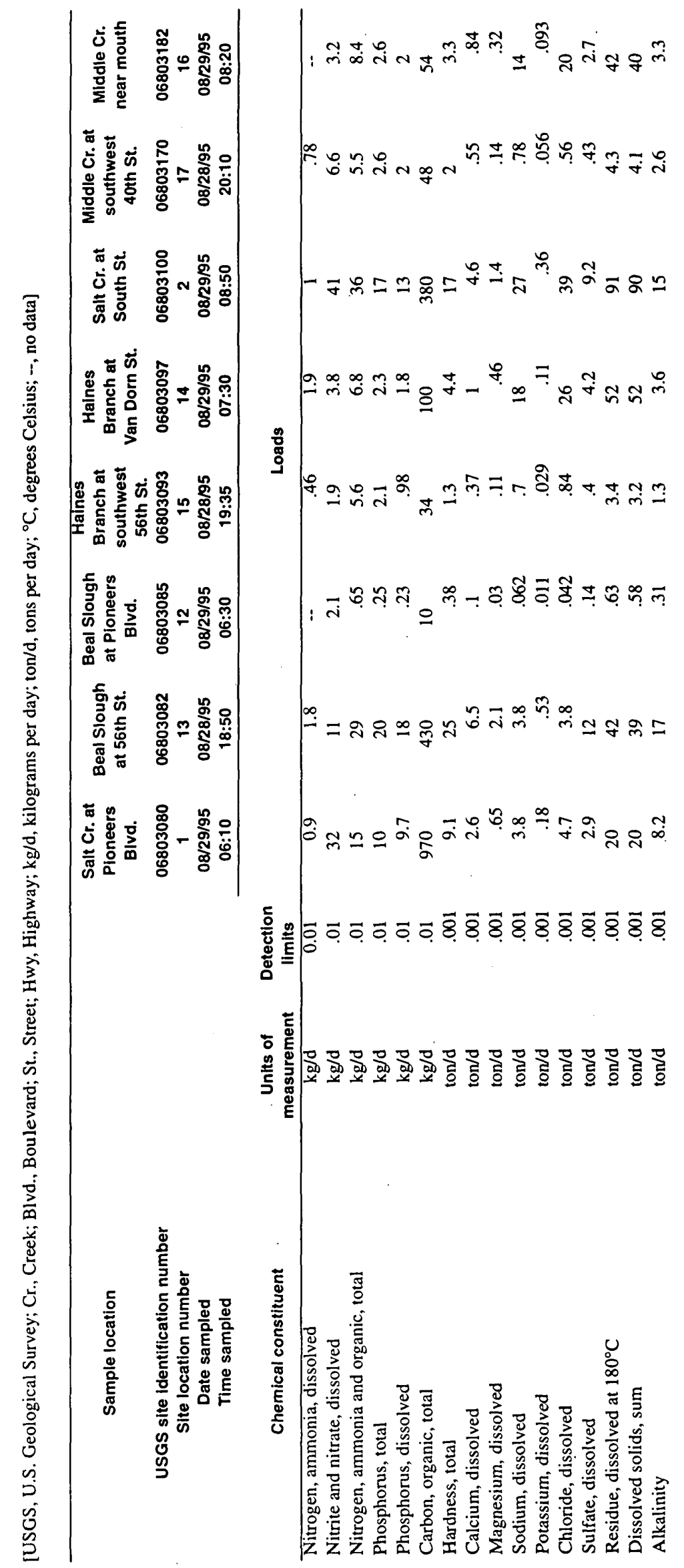




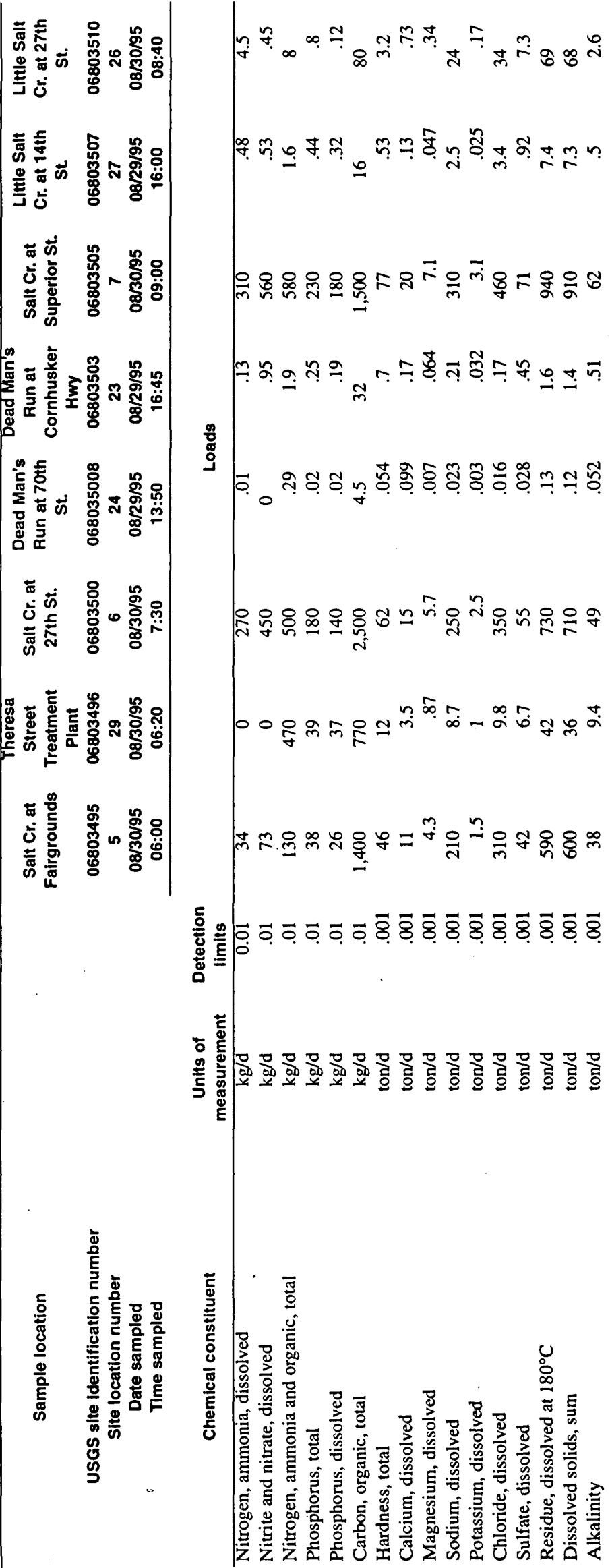




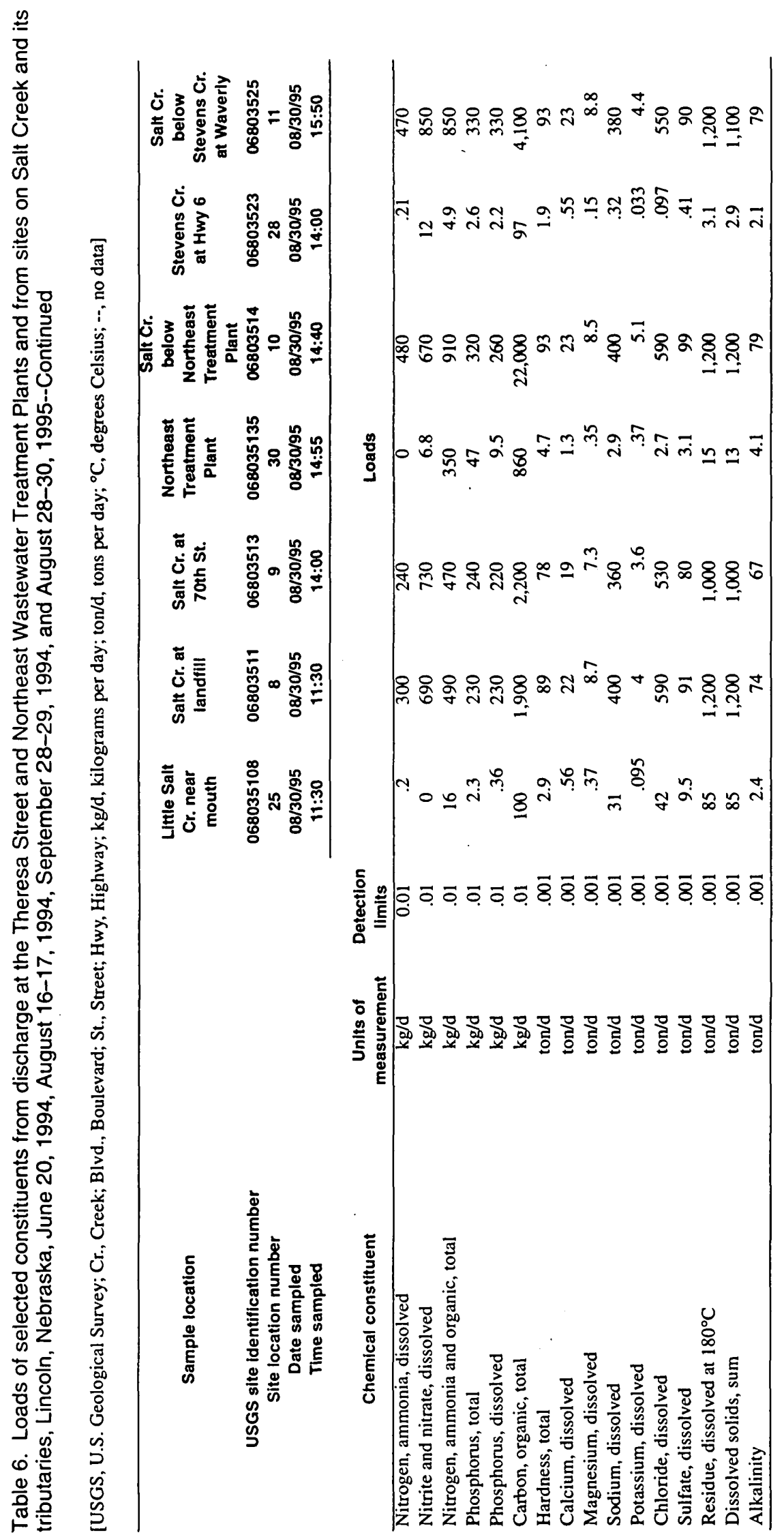




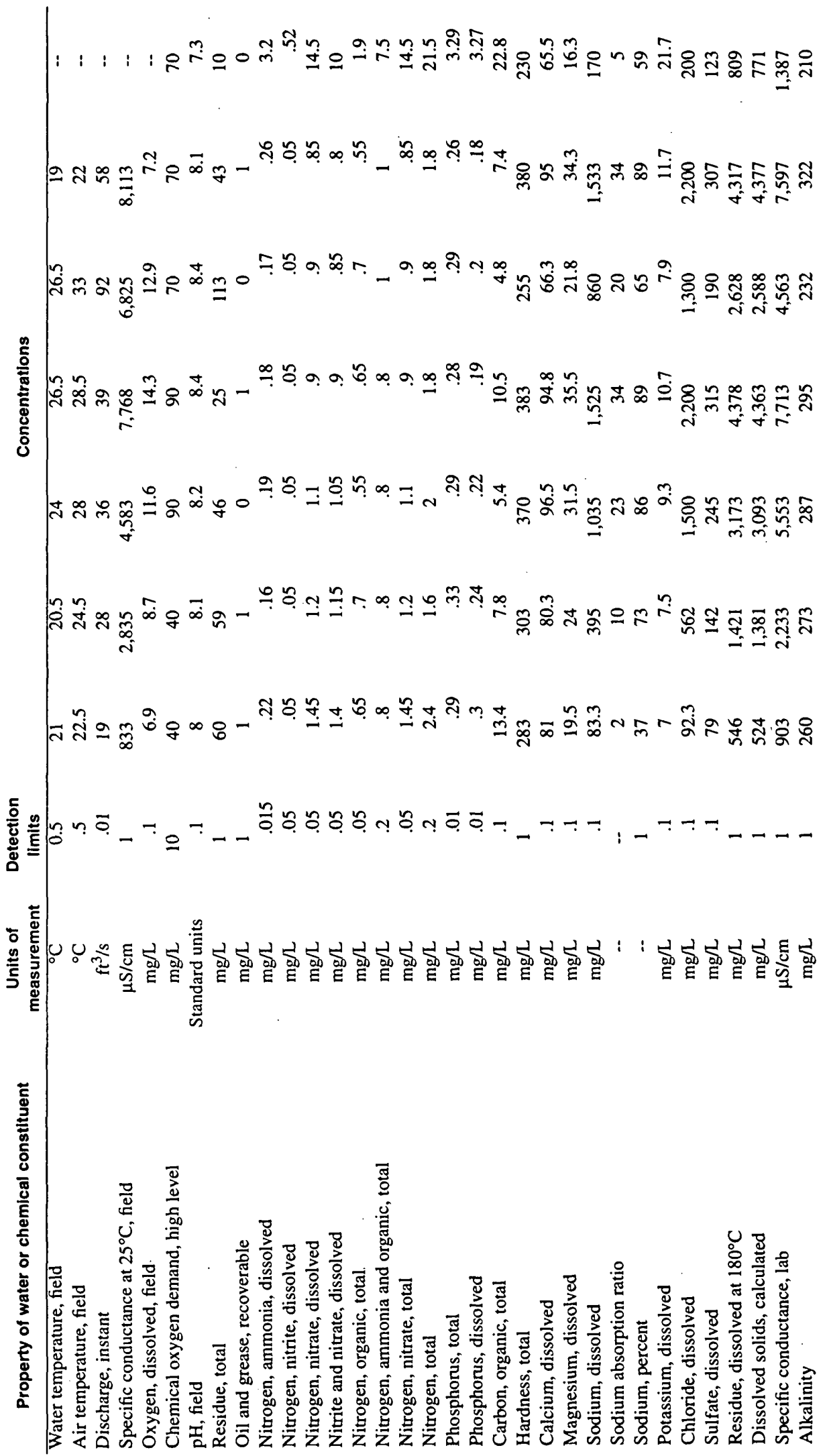




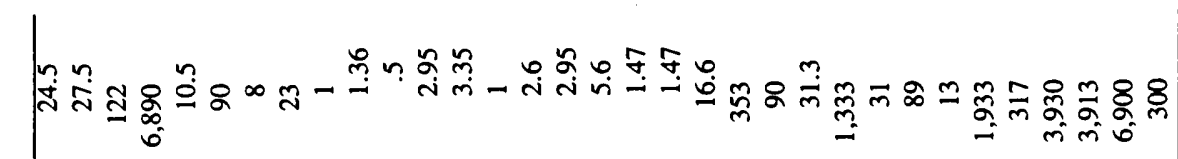

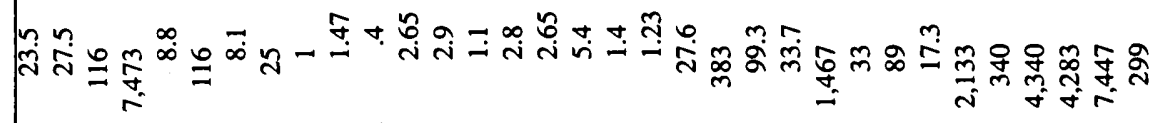

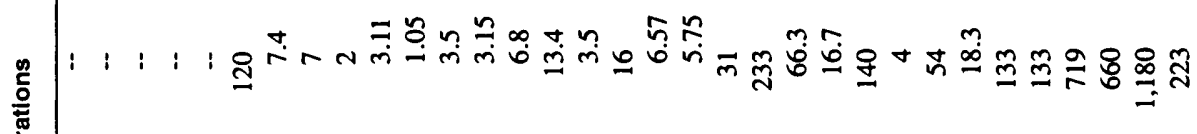

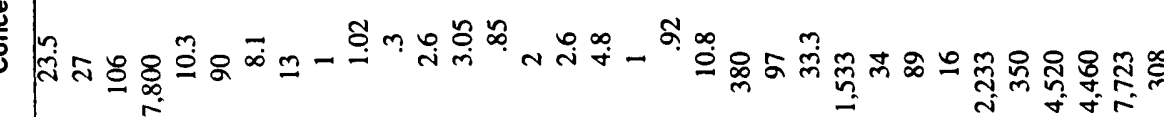

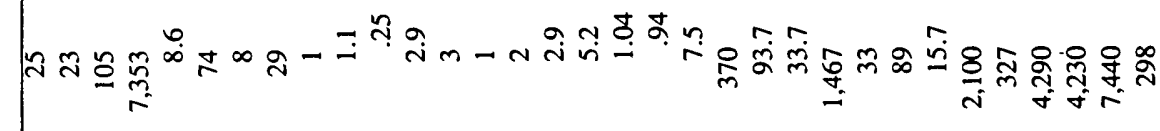
స त

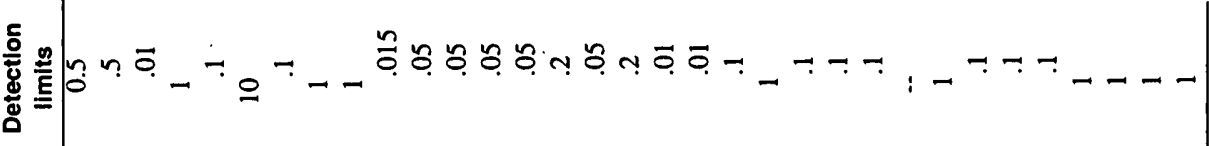

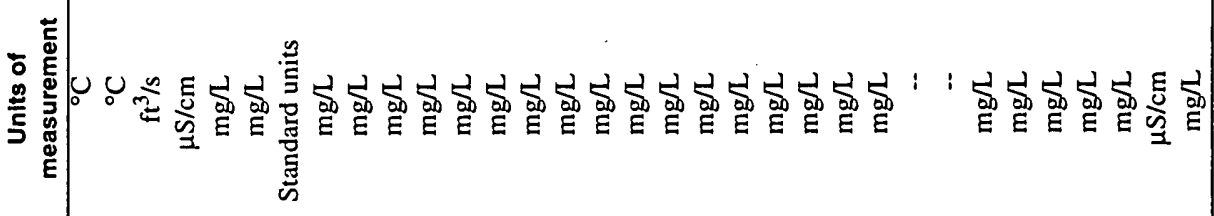

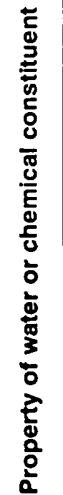




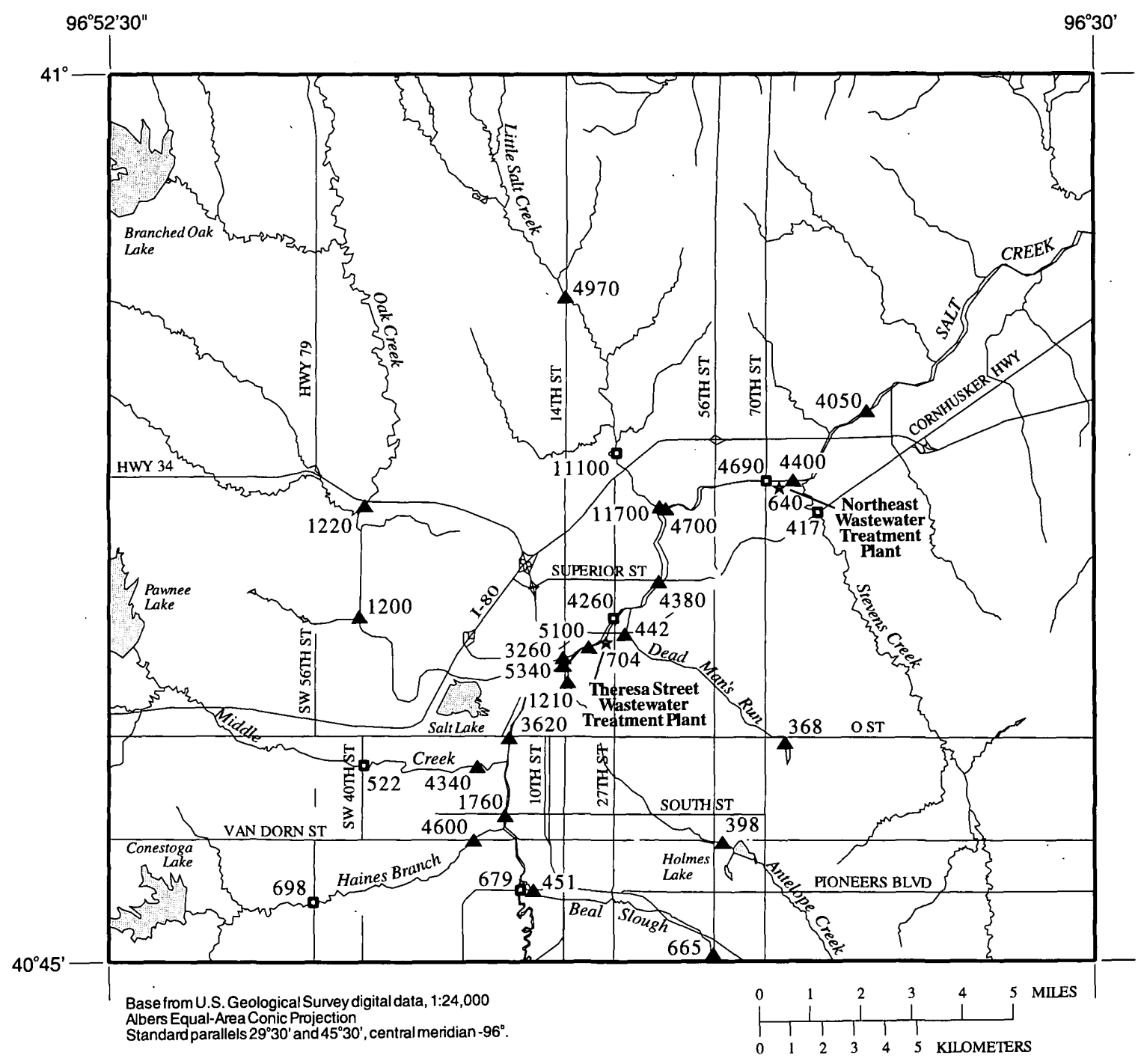

EXPLANATION

- Sampling site

* Wastewater-treatment plant

- Sampling site and gaging station

698 Dissolved solids, in milligrams per liter

Figure 16. Dissolved solids in surface-water samples from Salt Creek, its tributaries, and the Theresa Street and Northeast Wastewater Treatment Plants, Lincoln, Nebraska, August 28-30, 1995. 


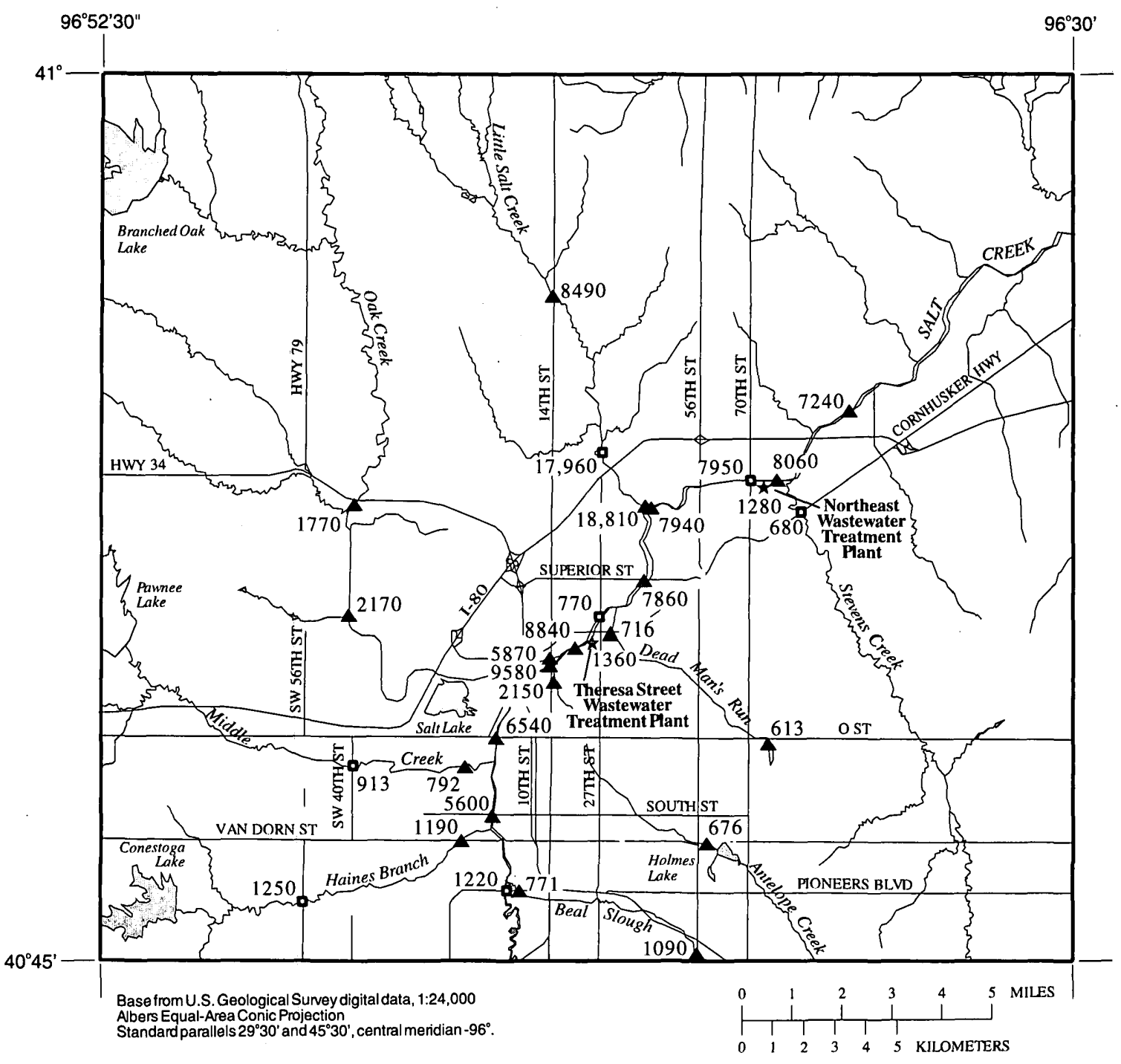

EXPLANATION
A Sampling site
* Wastewater-treatment plant
- Sampling site and gaging station

698 Specific conductance in microsiemens per centimeter at 25 degrees Celsius

Figure 17. Specific conductance in surface-water samples from Salt Creek, its tributaries, and the Theresa Street and Northeast Wastewater Treatment Plants, Lincoln, Nebraska, August 28-30, 1995. 


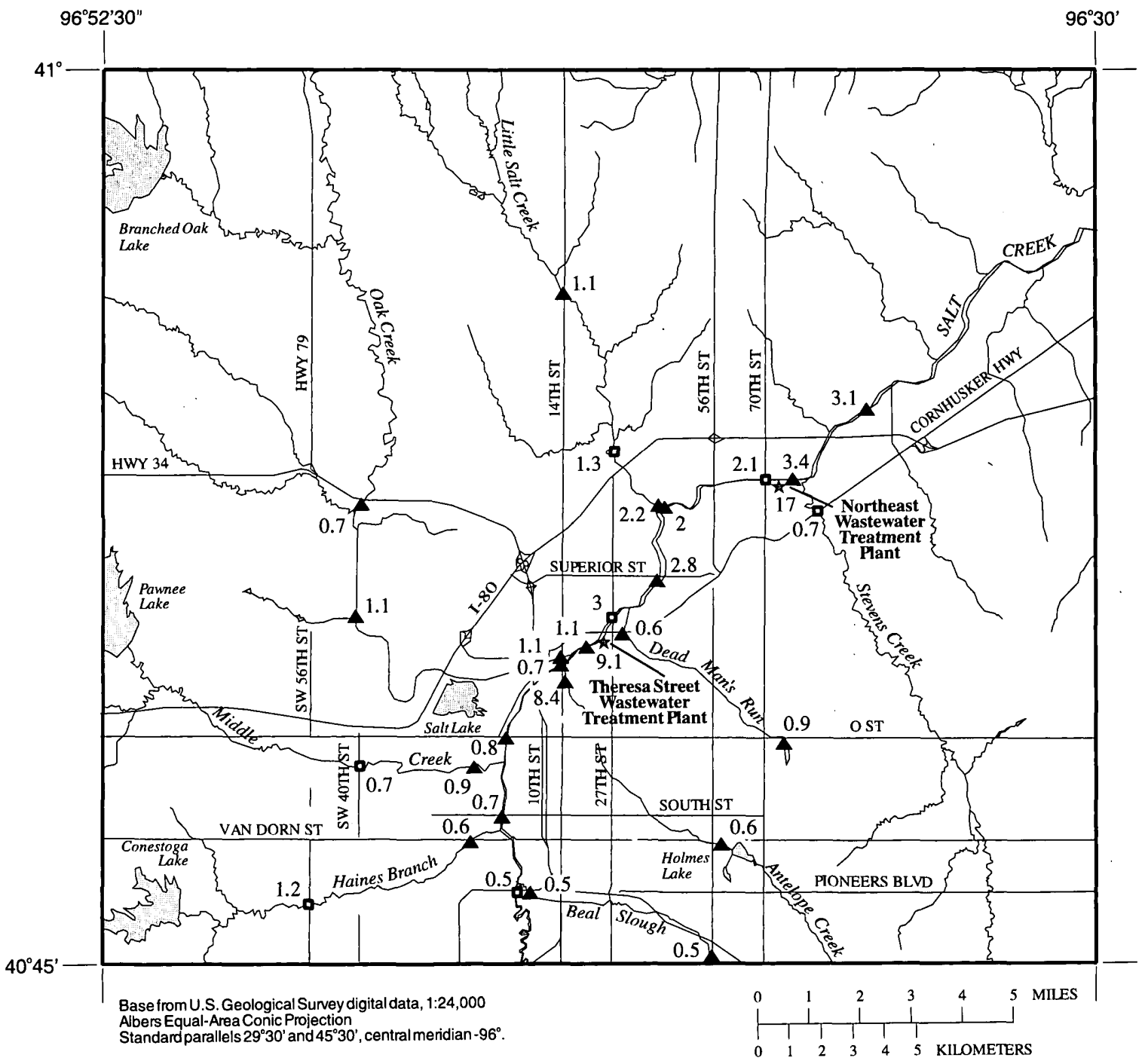

EXPLANATION
A Sampling site
* Wastewater-treatment plant
- Sampling site and gaging station
0.5 Total ammonia and organic nitrogen, in milligrams per liter

Figure 18. Total ammonia and organic nitrogen in surface-water samples from Salt Creek, its tributaries, and the Theresa Street and Northeast Wastewater Treatment Plants, Lincoln, Nebraska, August 28-30, 1995. 


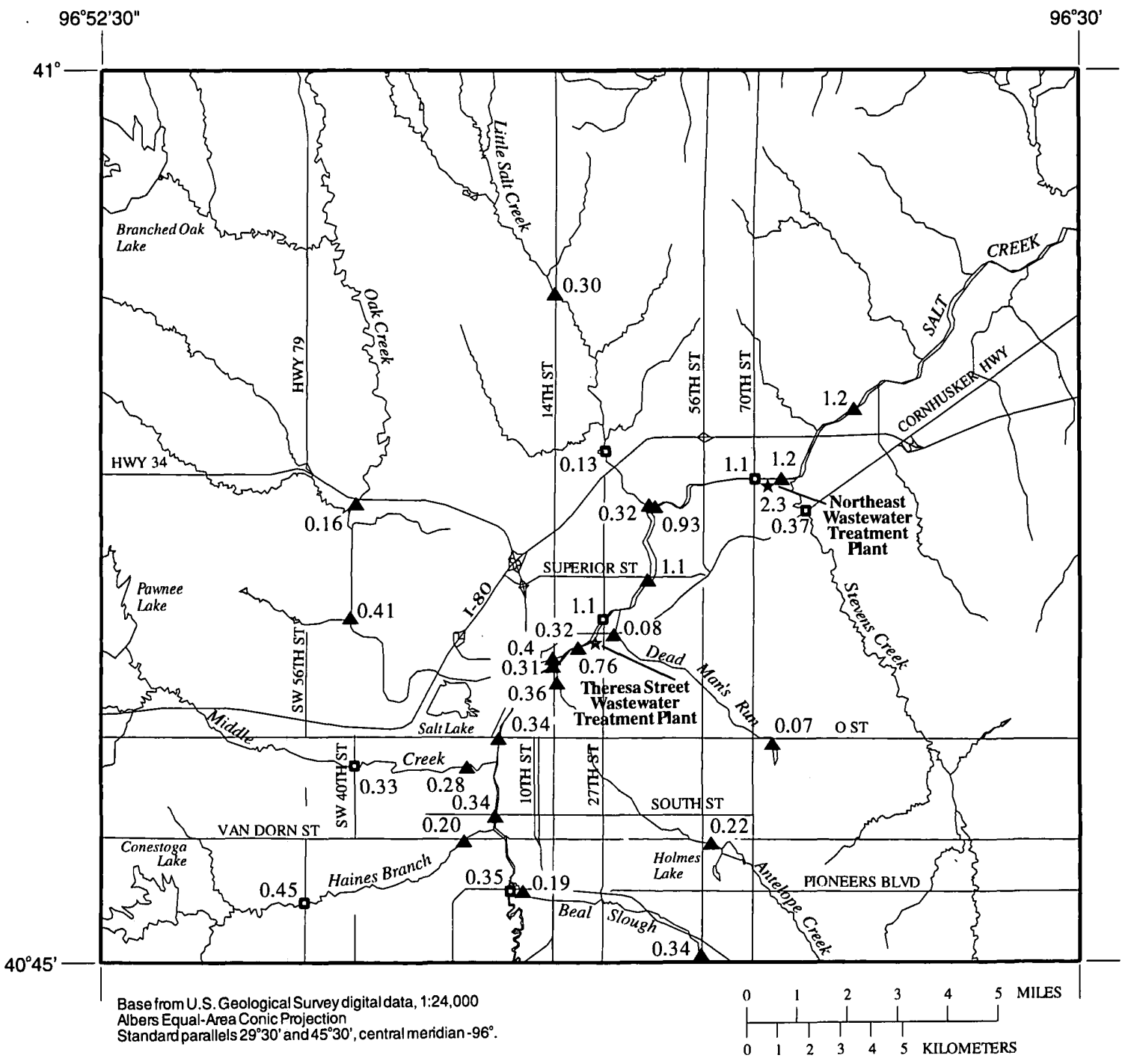

EXPLANATION
- Sampling site
* Wastewater-treatment plant
- Sampling site and gaging station
0.35 Total phosphorus, in milligrams per liter

Figure 19. Total phosphorus in surface-water samples from Salt Creek, its tributaries, and the Theresa Street and Northeast Wastewater Treatment Plants, Lincoln, Nebraska, August 28-30, 1995. 


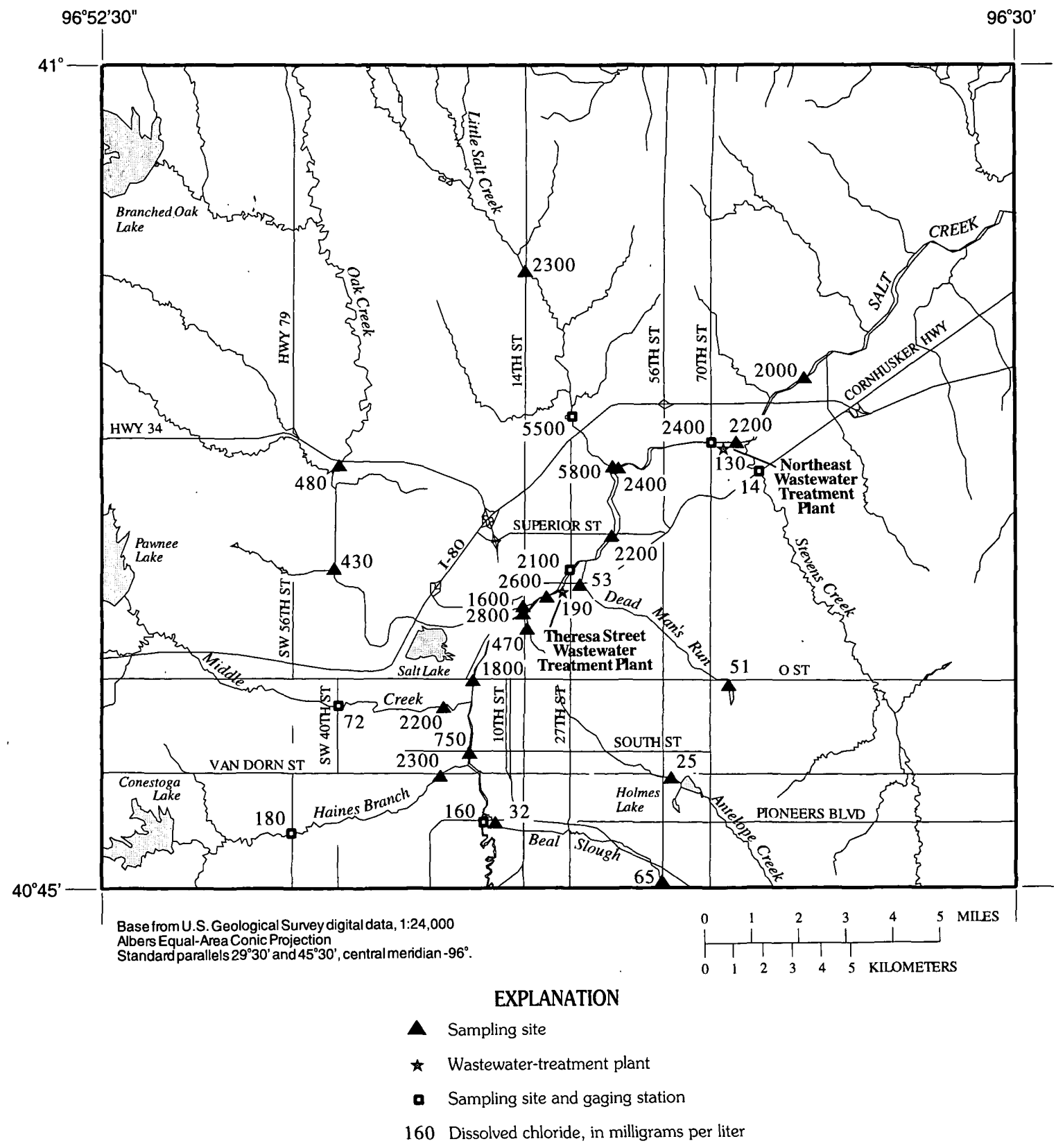

Figure 20. Dissolved chloride in surface-water samples from Salt Creek, its tributaries, the Theresa Street and Northeast Wastewater Treatment Plants, Lincoln, Nebraska, August 28-30, 1995. 
Table 8. Percent contributions of flow and selected constituents detected in samples from the Theresa Street and Northeast Wastewater Treatment Plants, Salt Creek, and its tributaries, Lincoln, Nebraska, June 20, 1994, August 16-17, 1994, September 28-29, 1994, and August 28-30, 1995

$[--$, no data $]$

\begin{tabular}{|c|c|c|c|c|c|c|c|c|c|c|c|c|}
\hline \multirow{3}{*}{$\begin{array}{l}\text { Discharge or } \\
\text { constituent }\end{array}$} & \multicolumn{12}{|c|}{ Percent contribution } \\
\hline & \multicolumn{4}{|c|}{ Wastewater-treatment plants } & \multicolumn{4}{|c|}{ Tributaries } & \multicolumn{4}{|c|}{ Ground water } \\
\hline & $\begin{array}{l}\text { Aug. } \\
1994\end{array}$ & $\begin{array}{l}\text { Sept. } \\
1994\end{array}$ & $\begin{array}{l}\text { Aug. } \\
1995\end{array}$ & Mean & $\begin{array}{l}\text { Aug. } \\
1994\end{array}$ & $\begin{array}{c}\text { Sept. } \\
94\end{array}$ & $\begin{array}{l}\text { Aug. } \\
1995\end{array}$ & Mean & $\begin{array}{l}\text { Aug. } \\
1994\end{array}$ & $\begin{array}{l}\text { Sept. } \\
1994\end{array}$ & $\begin{array}{l}\text { Aug. } \\
1995\end{array}$ & Mean \\
\hline Discharge & 26 & 42 & 29 & 32 & 49 & 40 & 35 & 41 & 25 & 18 & 36 & 26 \\
\hline $\begin{array}{l}\text { Ammonia and } \\
\text { organic nitrogen, total }\end{array}$ & -- & - & 96 & -- & -. & -- & 15 & -- & -- & -- & -11 & -- \\
\hline Phosphorus, total & - & -- & 26 & -- & -- & -- & 9 & -- & -- & -- & 65 & -- \\
\hline Organic carbon, total & - & -- & 62 & -- & -- & $\cdots$ & 29 & -- & -- & -- & 9 & -- \\
\hline Dissolved solids, sum & -. & -- & 5 & -. & -- & -- & 31 & -- & -- & -- & 64 & -- \\
\hline Dissolved sodium & -- & -- & 3 & -- & -- & -- & 32 & -- & -- & -- & 65 & -- \\
\hline Dissolved potassium & - & -- & 32 & -. & -- & -- & 22 & -- & -- & -- & 46 & - \\
\hline Dissolved chloride & - & -- & 2 & -- & -- & -- & 26 & -- & -- & - & 72 & -- \\
\hline
\end{tabular}




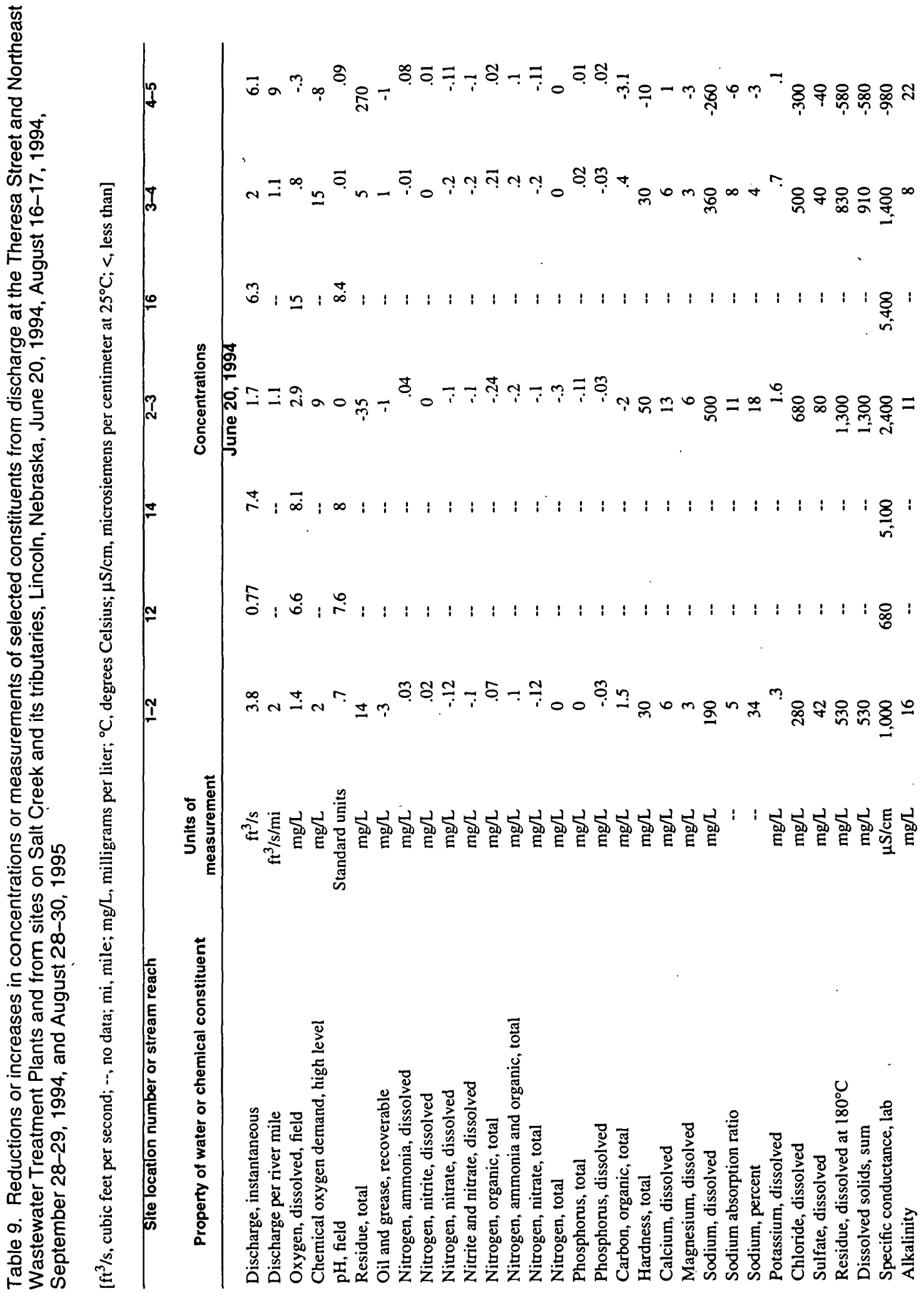




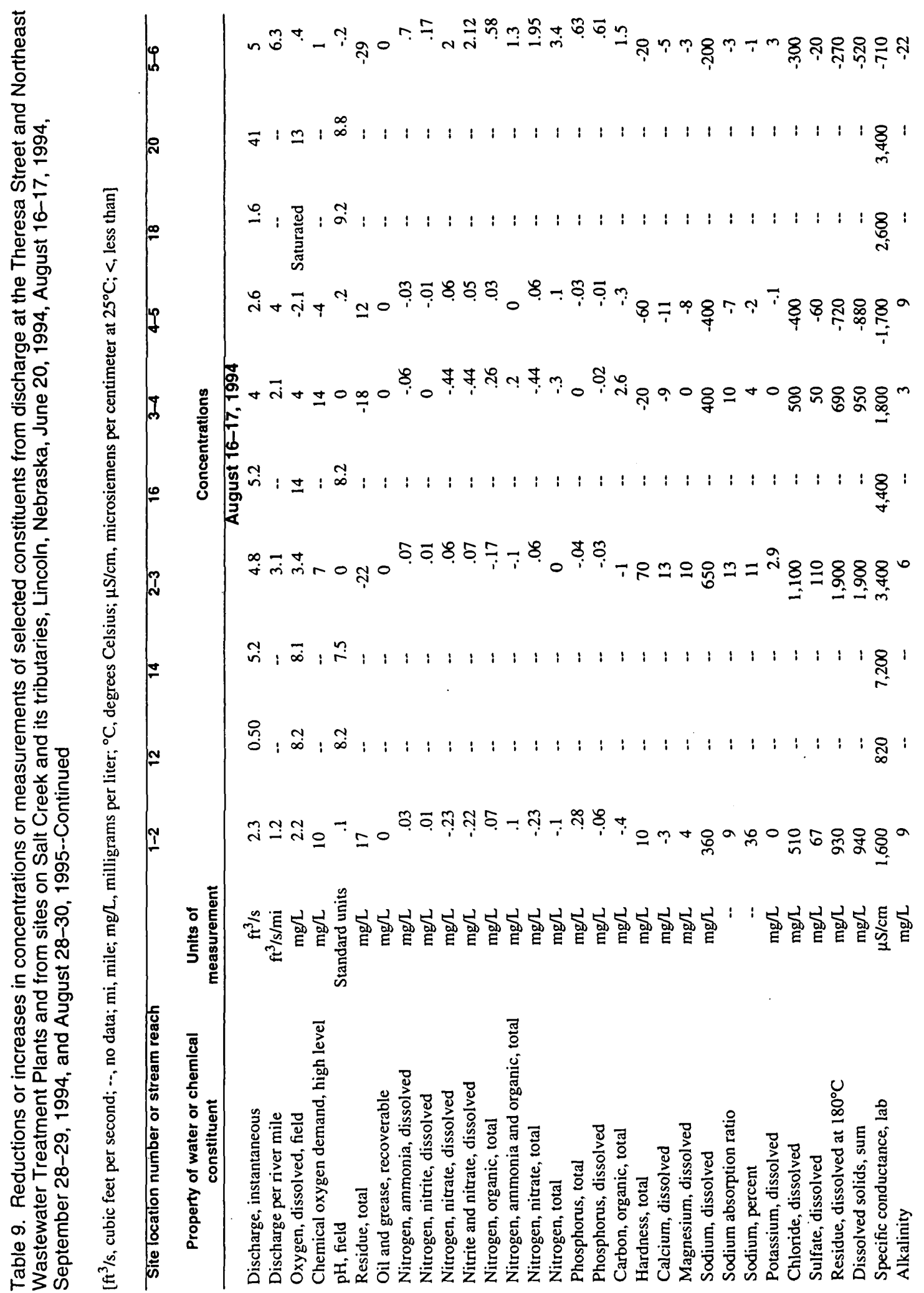




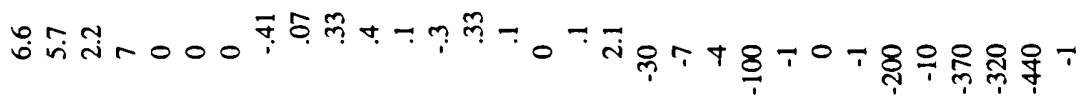

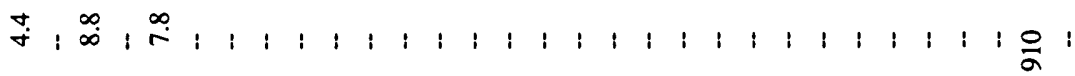

$$
\begin{aligned}
& \text { ทั่ }
\end{aligned}
$$




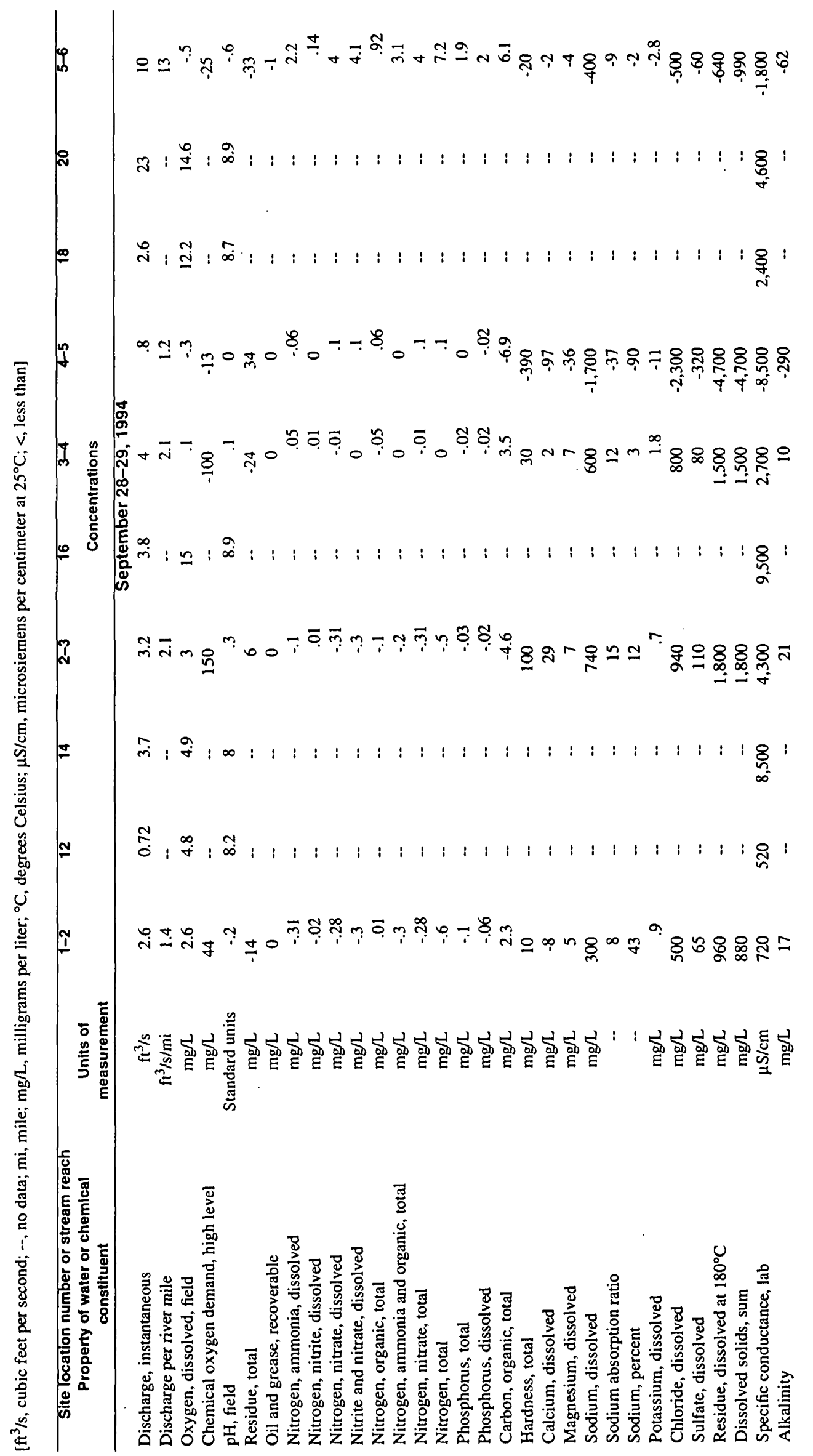




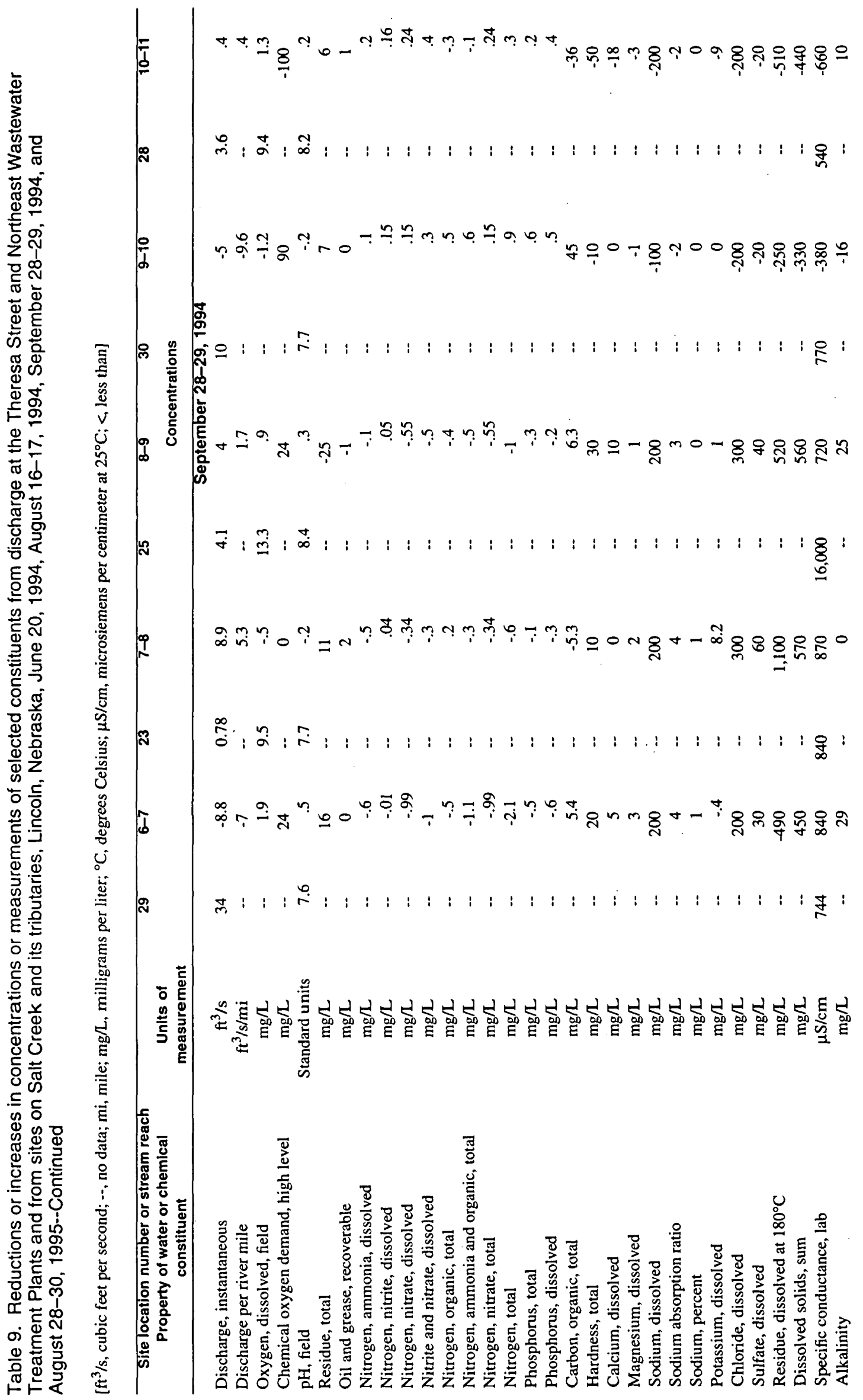

58 STREAMFLOW GAIN-AND-LOSS MEASUREMENTS AND WATER-QUALITY DATA OF SALT CREEK AND ITS TRIBUTARIES NEAR LINCOLN, NEBRASKA, 1994-95 


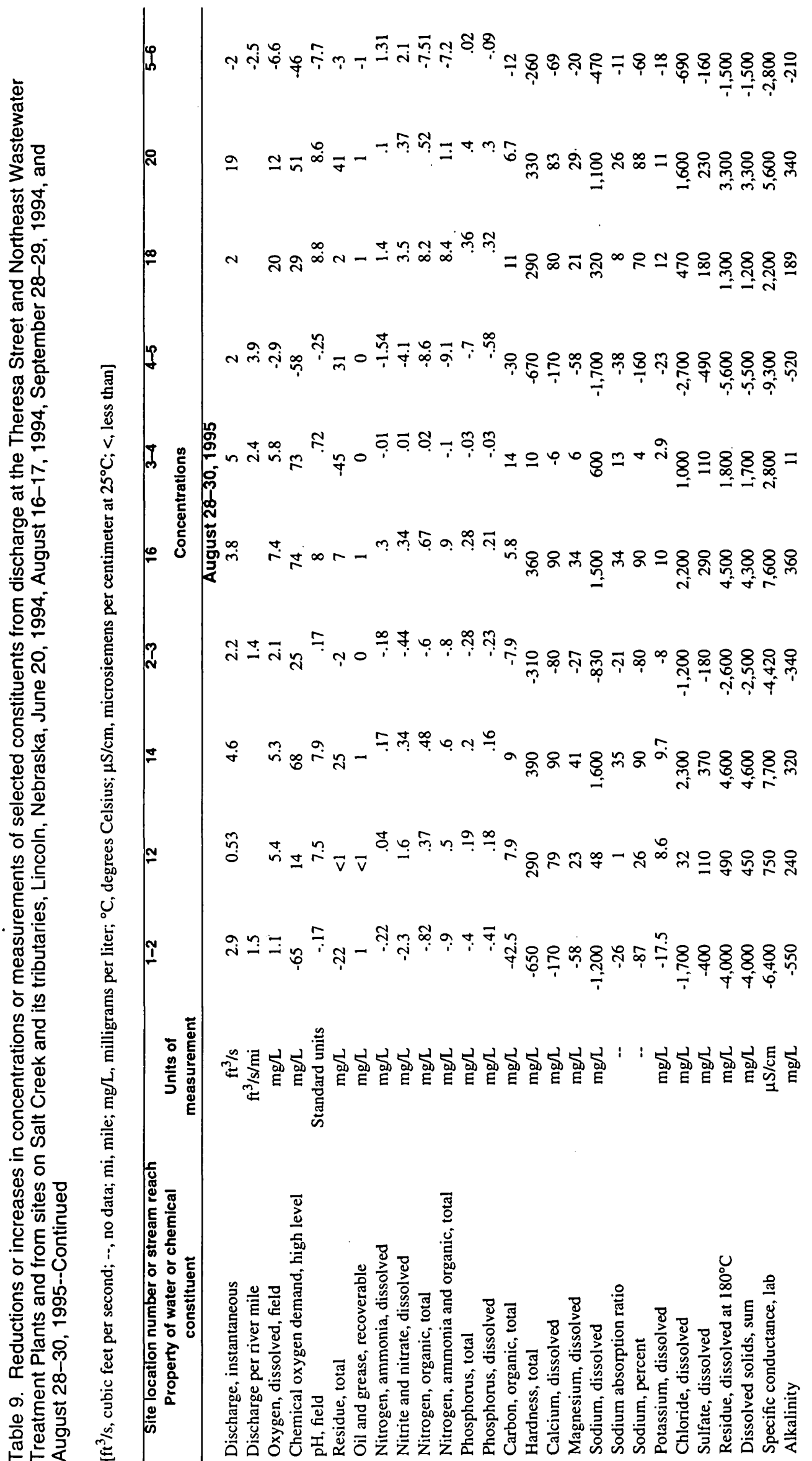




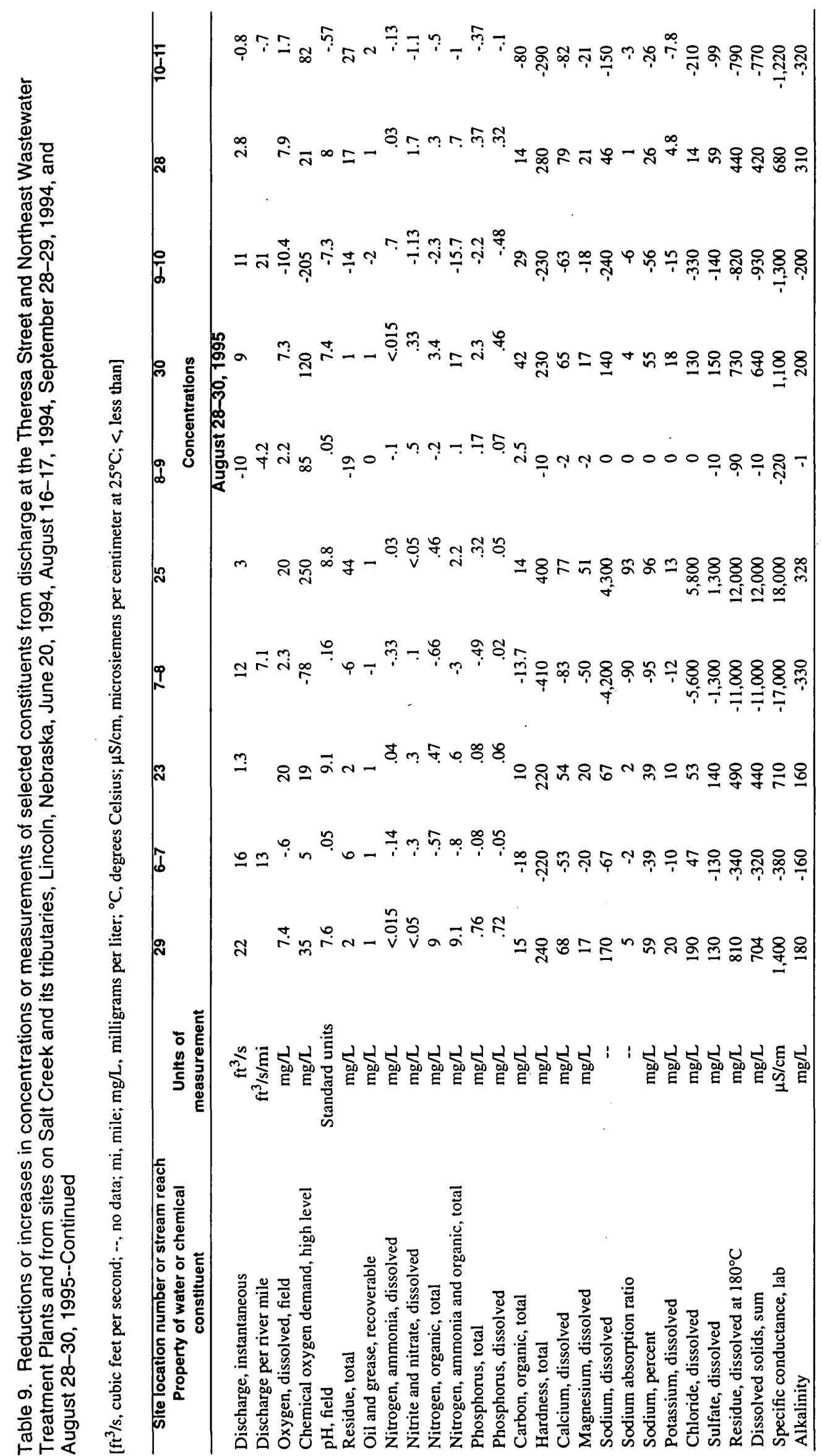

60 STREAMFLOW GAIN-AND-LOSS MEASUREMENTS AND WATER-QUALITY DATA OF SALT CREEK AND ITS TRIBUTARIES NEAR LINCOLN, NEBRASKA, 1994-95 


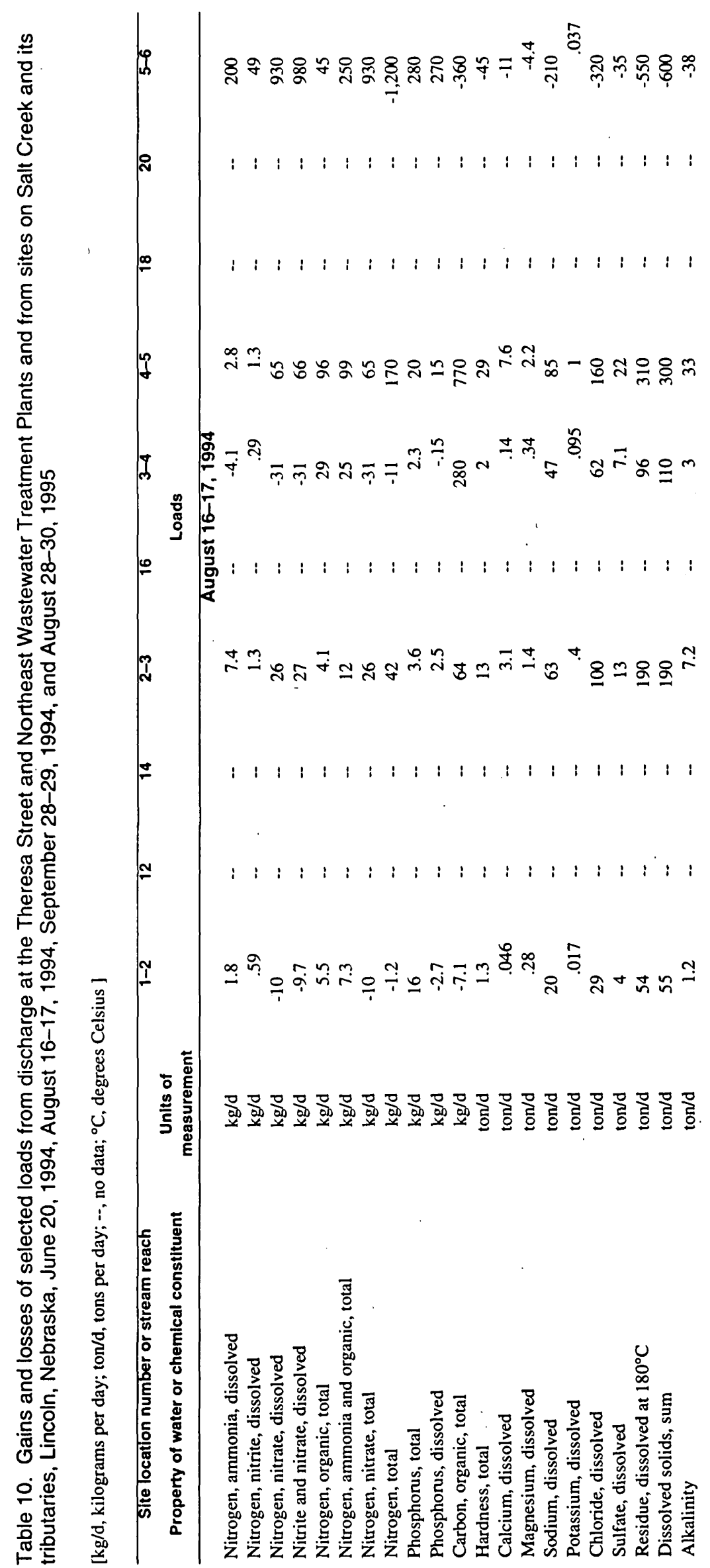




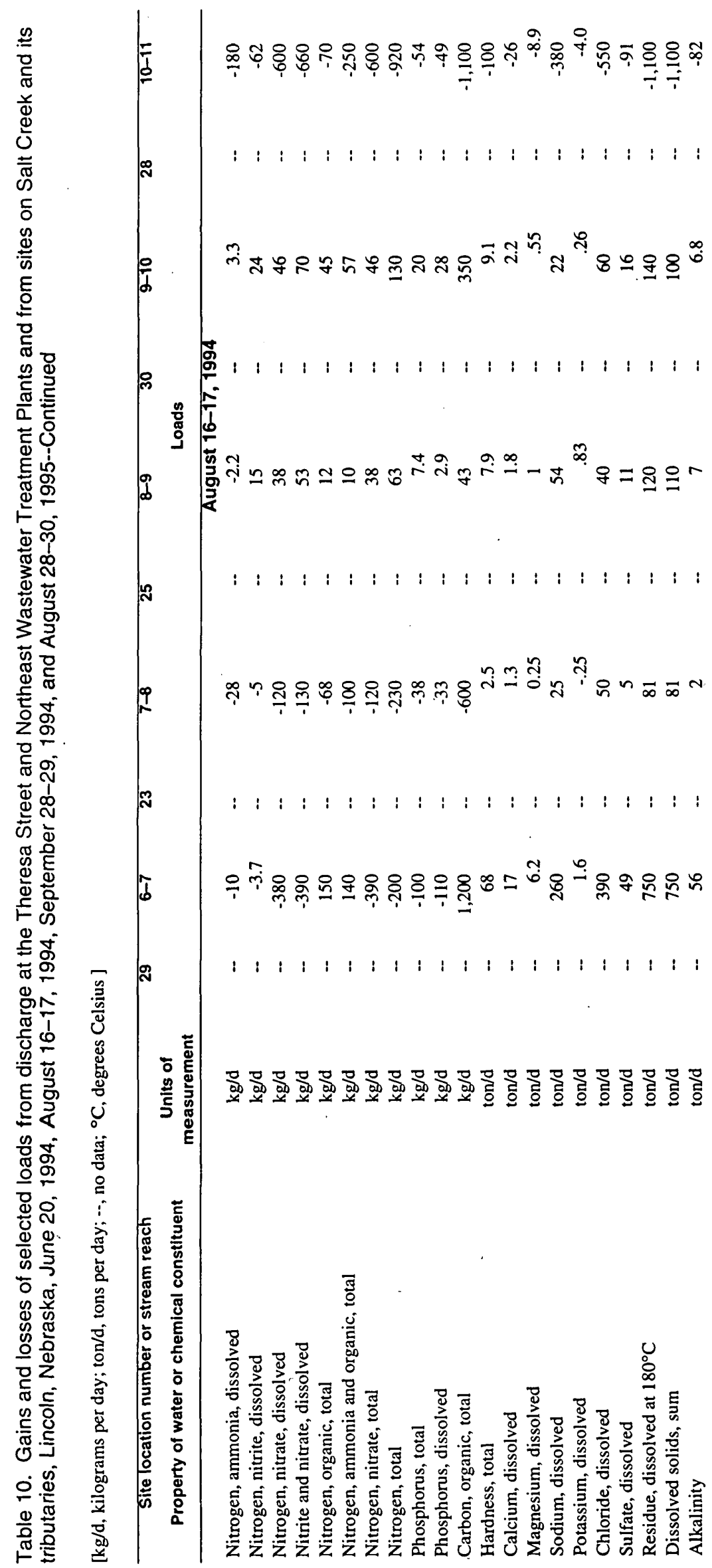

62 STREAMFLOW GAIN-AND-LOSS MEASUREMENTS AND WATER-QUALITY DATA OF SALT CREEK AND ITS TRIBUTARIES NEAR LINCOLN, NEBRASKA, 1994-95 


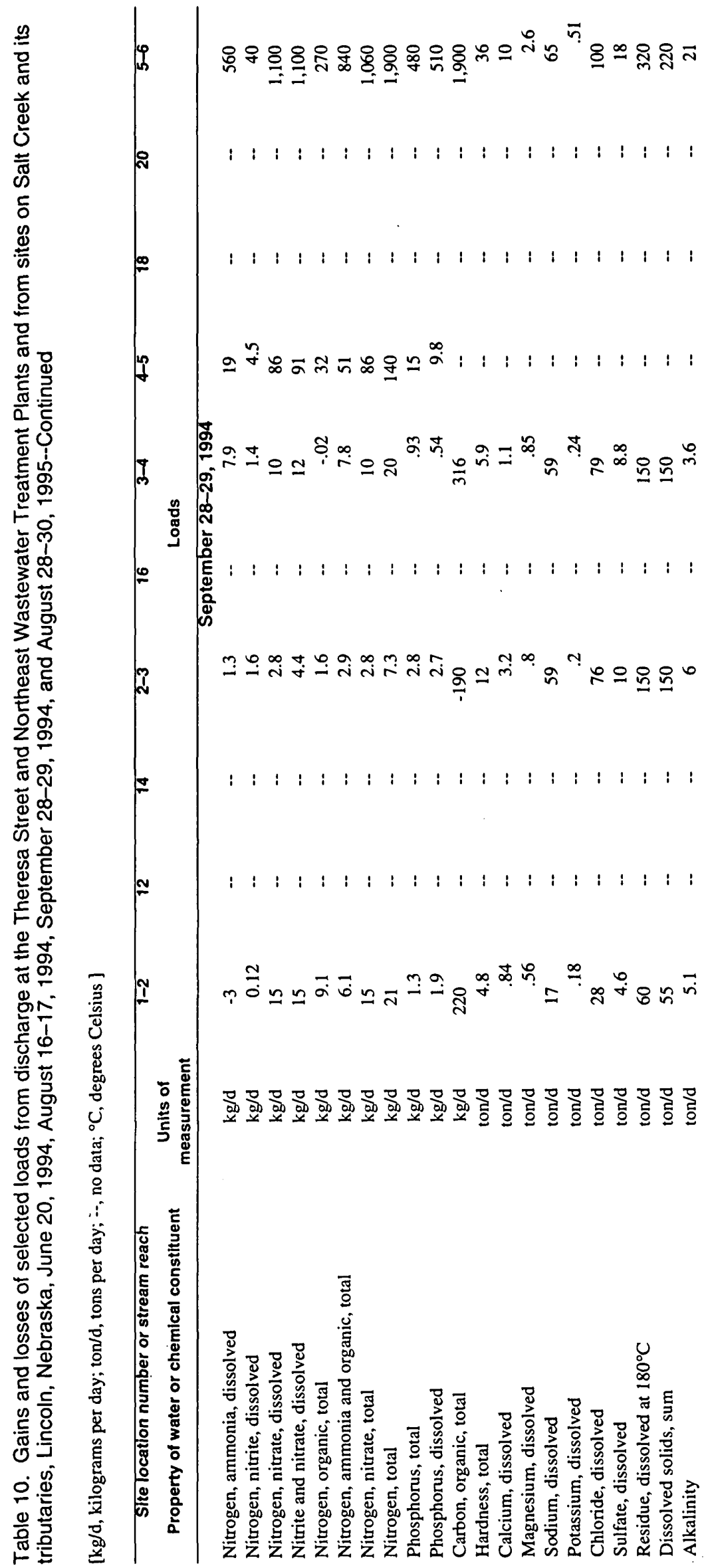




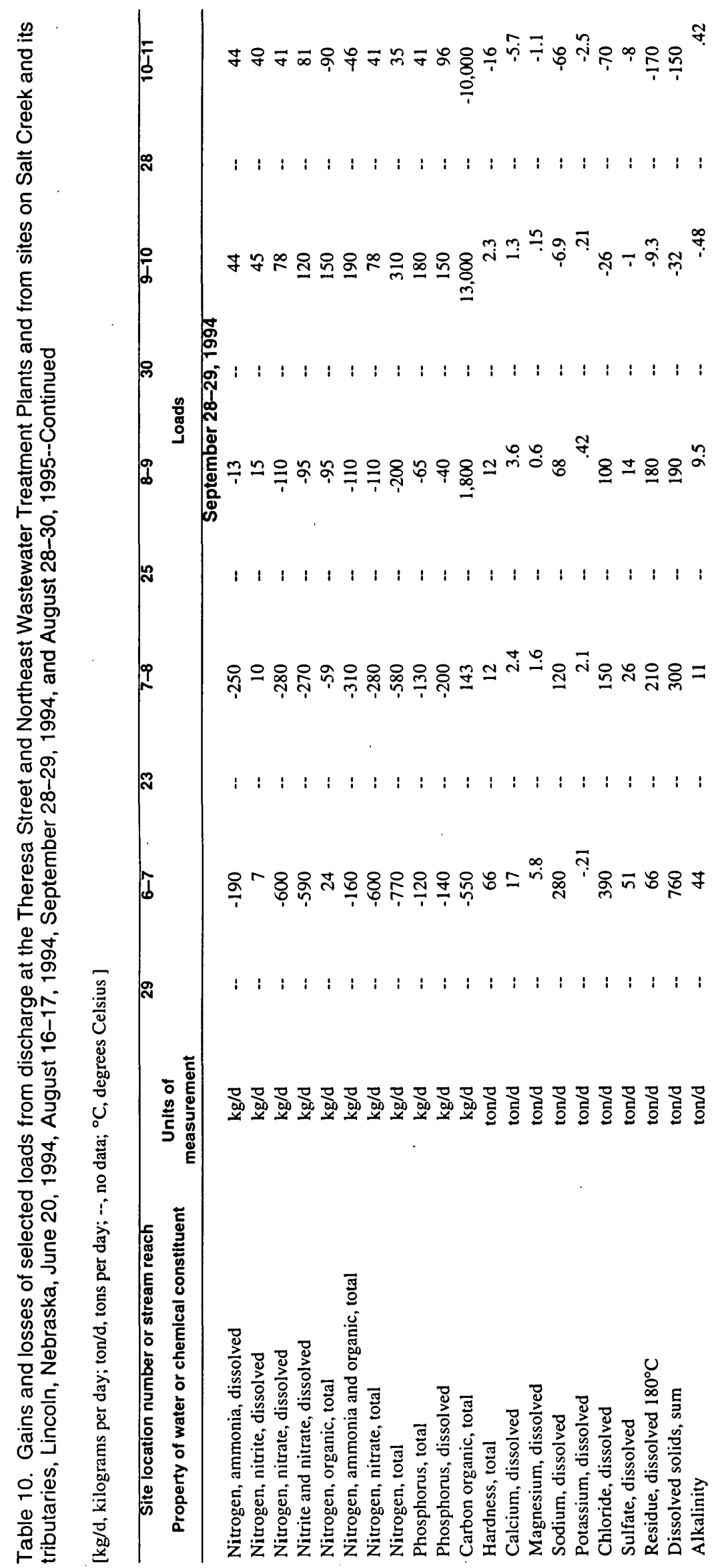

64 STREAMFLOW GAIN-AND-LOSS MEASUREMENTS AND WATER-QUALITY DATA OF SALT CREEK AND ITS TRIBUTARIES NEAR LINCOLN, NEBRASKA, 1994-95 


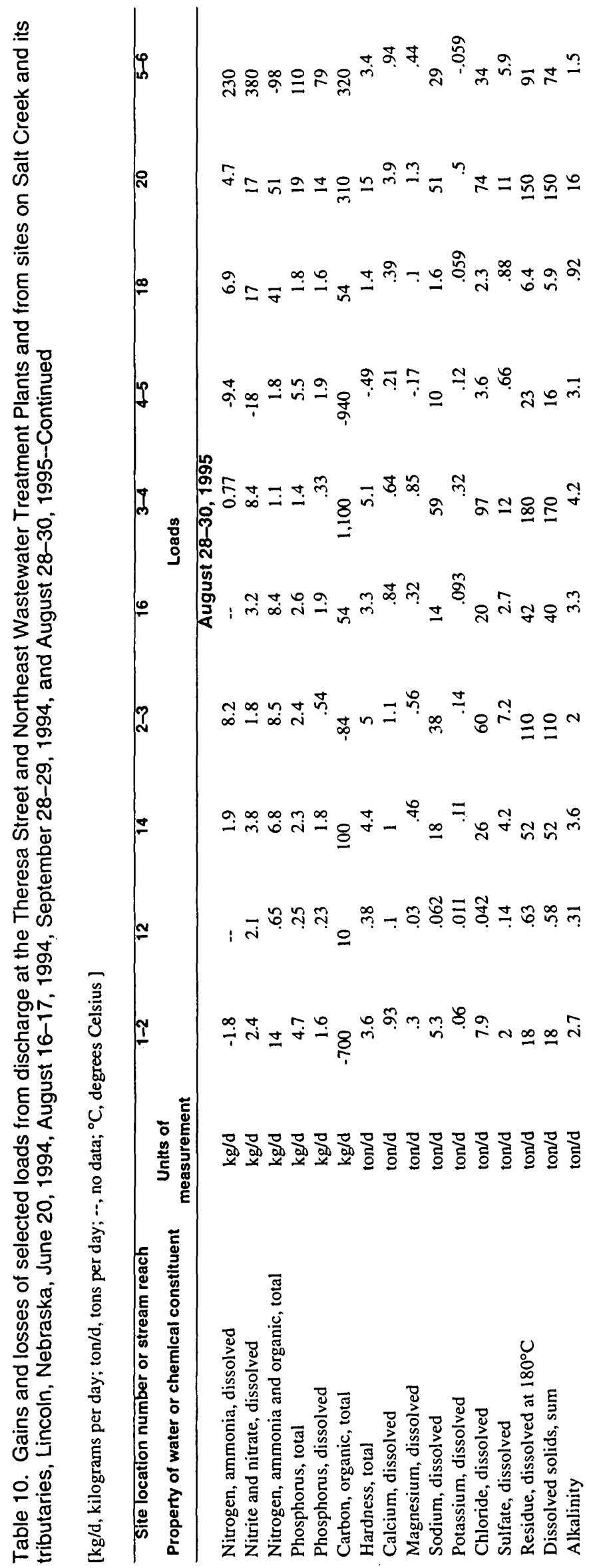




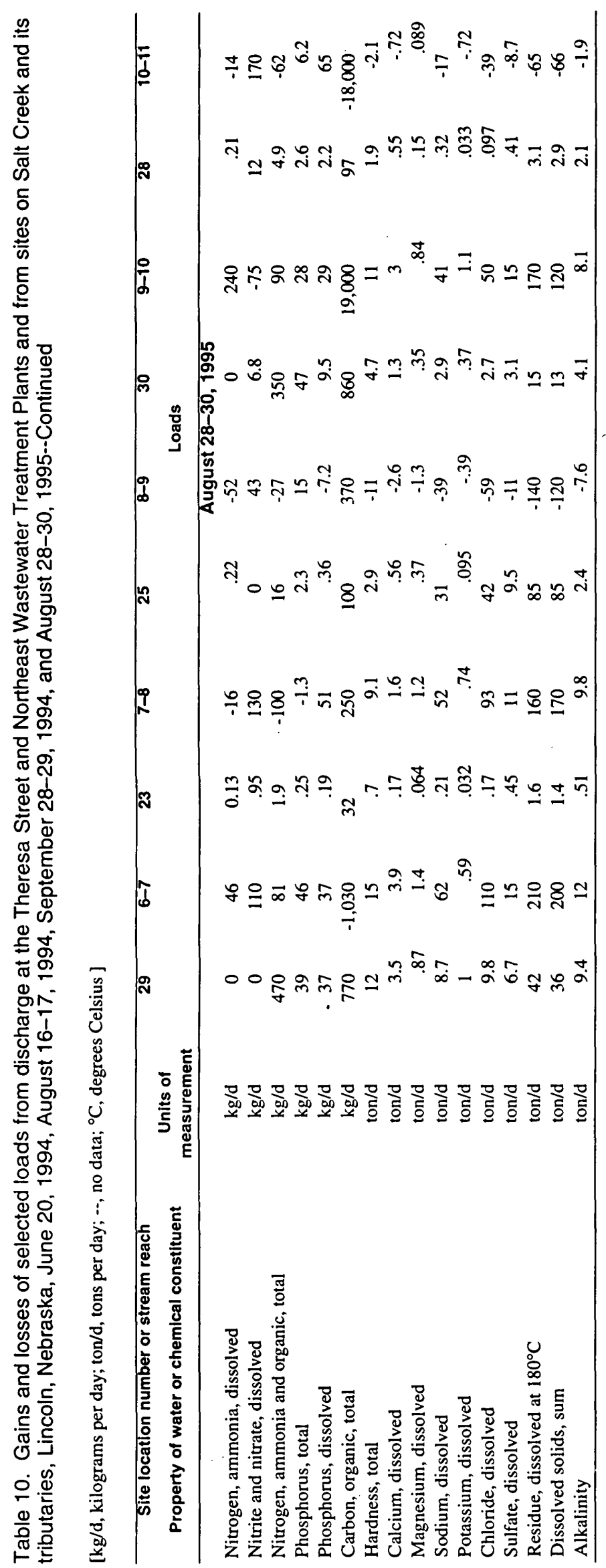

66 STREAMFLOW GAIN-AND-LOSS MEASUREMENTS AND WATER-QUALITY DATA OF SALT CREEK AND ITS TRIBUTARIES NEAR LINCOLN, NEBRASKA, 1994-95

4u.S. GOVERNMENT PRINTING OFFICE: $1997-573-382 / 26003$ REGION NO. 8 


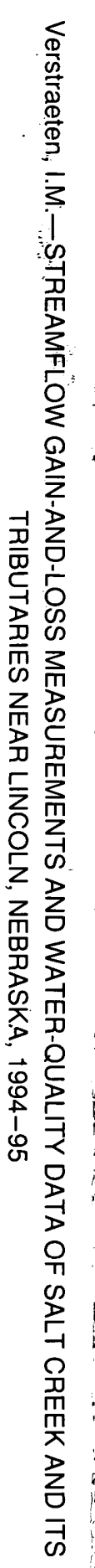

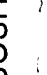

:

유

$\circ$

i. 